Wildlife Program

\title{
Modeling Least Bell's Vireo Habitat Suitability in Current and Historic Ranges in California
}

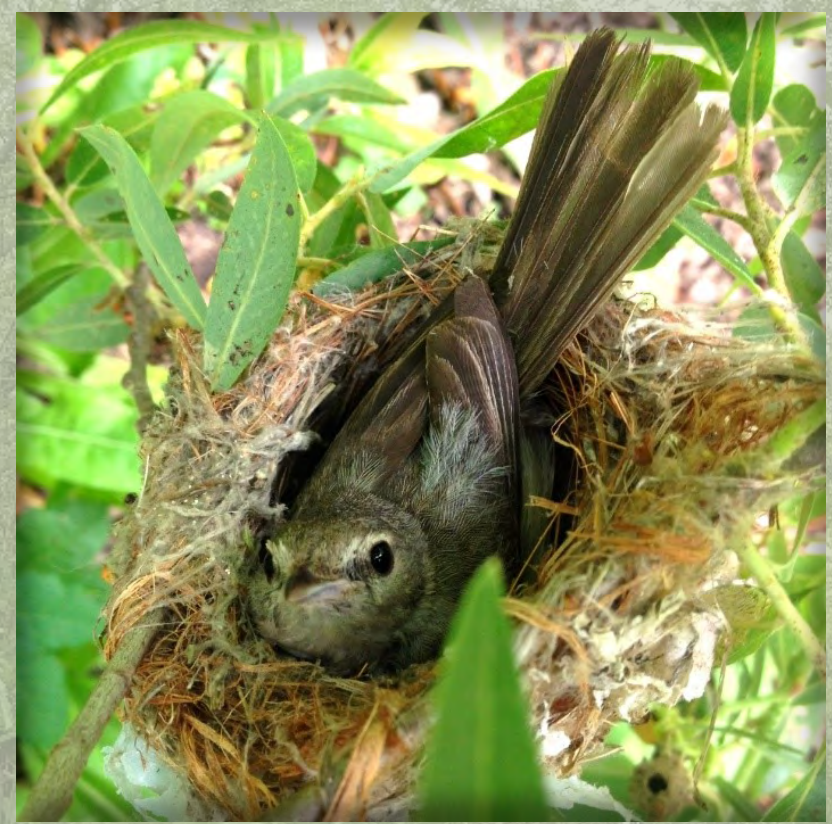

Open-File Report 2020-1151 
Cover Photos: (Front) A male vireo incubating a nest in the "Mars" territory on the Middle San Luis River. Photograph taken by Alexandra Houston, U.S. Geological Survey Western Ecological Research Center, June 15, 2012.

(Back) Least Bell's Vireo habitat, looking east along De Luz Creek. Photograph taken by Barbara Kus, U.S. Geological Survey Western Ecological Research Center, May 13, 2019. 


\section{Modeling Least Bell's Vireo Habitat Suitability in Current and Historic Ranges in California}

By Kristine L. Preston, Barbara E. Kus, and Emily Perkins

Wildlife Program

Open-File Report 2020-1151 


\section{U.S. Geological Survey, Reston, Virginia: 2021}

For more information on the USGS - the Federal source for science about the Earth, its natural and living resources, natural hazards, and the environment—visit https://www.usgs.gov or call 1-888-ASK-USGS.

For an overview of USGS information products, including maps, imagery, and publications, visit https://store.usgs.gov/.

Any use of trade, firm, or product names is for descriptive purposes only and does not imply endorsement by the U.S. Government.

Although this information product, for the most part, is in the public domain, it also may contain copyrighted materials as noted in the text. Permission to reproduce copyrighted items must be secured from the copyright owner.

Suggested citation:

Preston, K.L., Kus, B.E., and Perkins, E., 2021, Modeling Least Bell's Vireo habitat suitability in current and historic ranges in California: U.S. Geological Survey Open-File Report 2020-1151, 44 p., https://doi.org/10.3133/ofr20201151.

Associated data for this publication:

Preston, K.L., Kus, B.E., and Perkins, E.E., 2019, Least Bell's Vireo habitat suitability model for California (2019): U.S. Geological Survey data release, https://doi.org/10.5066/P90T9WT2.

ISSN 2331-1258 (online) 


\section{Acknowledgments}

We are grateful to the National Fish and Wildlife Foundation and Bureau of Land Management for funding the project. We thank our partners in the Collaborative Wildlife Protection and Recovery Initiative for their support of the project.

Thank you to U.S. Geological Survey colleagues, Ryan Pottinger and Shannon Mendia, for compiling vireo location and Geographic Information System datasets. We appreciate helpful comments by U.S. Geological Survey reviewers Jeff Tracey and Steven Hanser that improved the report. 



\section{Contents}

Acknowledgments ……...................................................................................................................

Abstract

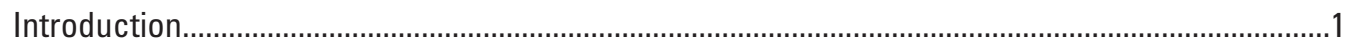

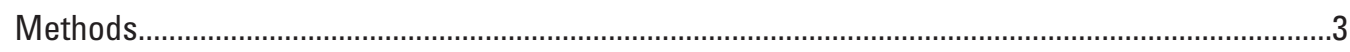

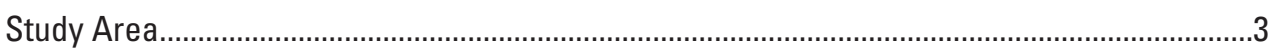

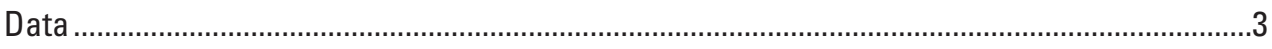

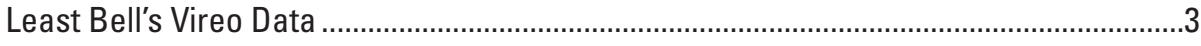

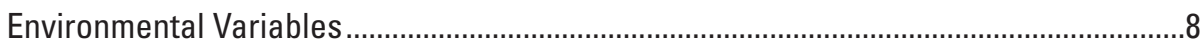

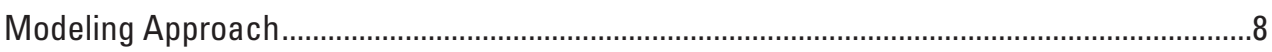

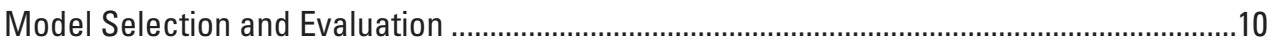

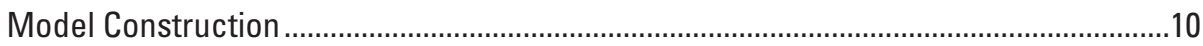

Quantitative Model Evaluation in the Current Range of Southern California ..................11

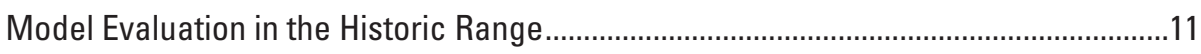

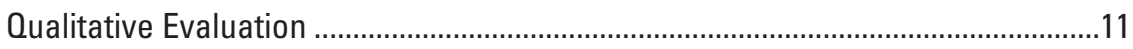

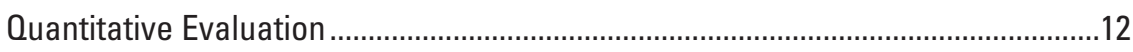

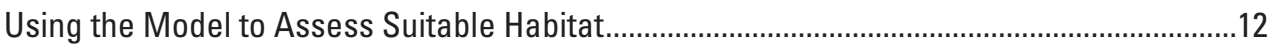

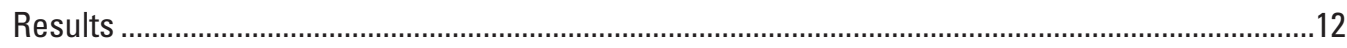

Southern California and California Environmental Grids ...................................................12

Southern California Habitat Modeling Results .................................................................12

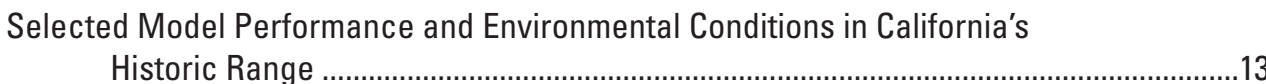

Amount of Suitable Habitat and Conservation in California ..............................................21

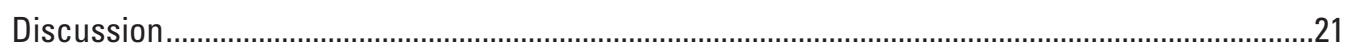

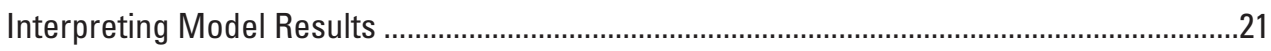

Application of Model to Conservation and Management......................................................22

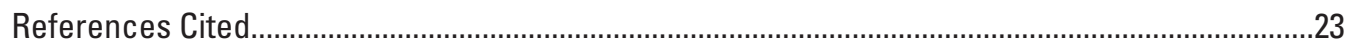

Appendix 1. Vegetation Maps for Various Geographic Areas of California and Selected

Riparian Vegetation Community Categories Used to Model Least Bell's Vireo Habitat.....26

Appendix 2. Twenty Top Performing Least Bell's Vireo Habitat Suitability Models......................29

Appendix 3. Suitable Habitat in California and Conservation Levels by County and

Hydrological Unit Code 8 Watersheds...............................................................................

\section{Figures}

1. Map showing California and southern California study areas with modeling extents defined by riparian vegetation communities potentially used by Least Bell's Vireos and buffered 500 meters by other types of land cover..

2. Map showing southern California Least Bell's Vireo spatially distinct location datasets for constructing alternative models and evaluating performance.

3. Map showing California Least Bell's Vireo California Natural Diversity Database historic and recent observations and eBird recent observations used to qualitatively evaluate model predictions in the historic range ..........................................

4. Map showing model R30-P1 habitat suitability predictions for the current range in southern California. 
5. Map showing model R30-P1 habitat suitability predictions for the historic range in California

6. Map showing model R30-P1 habitat suitability predictions and Least Bell's Vireo 1990-2018 locations used to construct and evaluate models for the current range in southern California

7. Map showing model R30-P1 habitat suitability predictions for the historic range in California

8. Map showing model R28-P1 habitat suitability predictions for the current range in southern California

9. Map showing model R28-P1 habitat suitability predictions for the historic range in California

\section{Tables}

1. Least Bell's Vireo location datasets used for habitat modeling with sources of observations, total number of observations per dataset, and how datasets were used in model construction and evaluation in the current and historic ranges......5

2. Description of variables included in the southern California and California environmental grids to create alternative Least Bell's Vireo models.

3. Environmental variable means and standard deviation calculated for the Least Bell's Vireo model construction dataset and for the riparian modeling grids in historic and current ranges

4. Assessment of historic and recent Least Bell's Vireo observations and R30-P1 model performance in California's historic range.

5. Comparison of environmental variable means and standard deviation calculated for suitable and unsuitable habitat across California, for Least Bell's Vireo locations in the current range and for historic and recent vireo observation areas in the historic range 


\section{Conversion Factors}

International System of Units to U.S. customary units

\begin{tabular}{|c|c|c|}
\hline Multiply & By & To obtain \\
\hline \multicolumn{3}{|c|}{ Length } \\
\hline meter (m) & 3.281 & foot (ft) \\
\hline $\begin{array}{l}\text { kilometer } \\
(\mathrm{km})\end{array}$ & 0.6214 & mile (mi) \\
\hline \multicolumn{3}{|c|}{ Area } \\
\hline hectare (ha) & 2.471 & acre \\
\hline
\end{tabular}

Temperature in degrees Celsius $\left({ }^{\circ} \mathrm{C}\right)$ may be converted to degrees Fahrenheit $\left({ }^{\circ} \mathrm{F}\right)$ as follows:

$$
{ }^{\circ} \mathrm{F}=\left(1.8 \times{ }^{\circ} \mathrm{C}\right)+32 \text {. }
$$

Temperature in degrees Fahrenheit $\left({ }^{\circ} \mathrm{F}\right)$ may be converted to degrees Celsius $\left({ }^{\circ} \mathrm{C}\right)$ as follows:

$$
{ }^{\circ} \mathrm{C}=\left({ }^{\circ} \mathrm{F}-32\right) / 1.8 \text {. }
$$




\section{Abbreviations}

$\begin{array}{ll}\text { AUC } & \text { area under the curve } \\ \text { CNDDB } & \text { California Natural Diversity Database } \\ \text { CWD } & \text { cumulative water deficit } \\ \text { FRAP } & \text { Fire Resource Assessment Program } \\ \text { GIS } & \text { Geographic Information System } \\ \text { HSI } & \text { habitat similarity index } \\ \text { HUC } & \text { hydrological unit code } \\ \text { NDVI } & \text { normalized difference vegetation index } \\ \text { SAWA } & \text { Santa Ana Watershed Association } \\ \text { std } & \text { standard deviation } \\ \text { USFWS } & \text { U.S. Fish and Wildlife Service } \\ \text { WRC MSHCP } & \text { Western Riverside County Multiple Species Habitat Conservation Plan }\end{array}$




\title{
Modeling Least Bell's Vireo Habitat Suitability in Current and Historic Ranges in California
}

\author{
By Kristine L. Preston, Barbara E. Kus, and Emily Perkins
}

\section{Abstract}

We developed a habitat suitability model for the federally endangered Least Bell's Vireo (Vireo bellii pusillus) across its current and historic range in California. The vireo disappeared from most of its range by the 1980s, remaining only in southern California and northern Baja California, Mexico. This decline was due to habitat loss and introduction of brood parasitic brown-headed cowbirds (Molothrus ater) into California in the late 1800s. Habitat protection and management since the mid-1980s increased southern California vireo populations with small numbers of birds recently expanding back into the historic range. The vireo habitat model will help meet the U.S. Fish and Wildlife Service recovery objectives by distinguishing specific areas to survey for new occurrences; characterizing important vireo-habitat relationships; and identifying areas for habitat management. We constructed models based on the vireo's current range to predict suitable habitat in the historic range, which differs substantially in environmental conditions. We used the partitioned Mahalanobis $\mathrm{D}^{2}$ modeling technique designed to predict habitat suitability in areas not included in a sample of species locations and under novel conditions. We constructed alternative models with different combinations of environmental variables hypothesized to be important components of vireo habitat. We selected a set of best performing models to predict suitable habitat for a riparian vegetation grid buffered 500 meters across California. Most models for southern California did not predict suitable habitat in the historic range. The top performing model has an area under the curve value of 0.93 . It is a simple model and discriminated among riparian habitats, with only 6 percent predicted as suitable. On average, suitable vireo habitat had more than 60-percent riparian vegetation and flat land at the 150-meter scale, little-to-no slope, and was within 130 meters of water.

\section{Introduction}

Least Bell's Vireo (Vireo bellii pusillus) is a small migratory songbird currently restricted as a breeding resident to dense willow-dominated riparian habitats along streams, rivers, and floodplains in southwestern California, United States and northwestern Baja California, Mexico. Three other subspecies of Bell's vireo have separate geographic breeding ranges in the United States and northern Mexico, and all subspecies winter in Mexico (Kus and others, 2020). This subspecies was listed as endangered by the state of California in 1980 and by the federal government in 1986. Historically, Least Bell's Vireo was one of the most abundant songbird species in the lowlands of California, including the central coast and San Joaquin and Sacramento Valleys (U.S. Fish and Wildlife Service, 1998). At the time of federal listing, the species was considered to have declined more dramatically than any other songbird species in the state (U.S. Fish and Wildlife Service, 1986). Reductions in vireo populations were first noted in the 1930s and 1940s (U.S. Fish and Wildlife Service, 1986). By the 1970s, vireos had disappeared from the northern and central parts of their historic breeding range, including from Tehama County in the northern Sacramento Valley and south through the San Joaquin Valley and major river systems on the central coast (Goldwasser and others, 1980; U.S. Fish and Wildlife Service, 1986). By 1985, there were only 291 known territories remaining in southwestern California, with the greatest concentration in San Diego County (U.S. Fish and Wildlife Service, 1986). 
Least Bell's Vireo populations disappeared in response to large-scale loss of California's riparian habitat to agricultural and urban land uses, flood control projects, gravel extraction, and livestock grazing (U.S. Fish and Wildlife Service, 1986, 1998; Kus and others, 2020). In the late 1970s, it was estimated that 90 percent of riparian habitat had disappeared from areas in California where vireos were present during the 1850s (Smith, 1977). A second factor associated with the vireo's decline is brown headed-cowbird (Molothrus ater) brood parasitism (U.S. Fish and Wildlife Service, 1986, 1998; Kus and others, 2020). Female cowbirds lay their eggs in vireo nests and the vireo eggs typically are destroyed by the female or nestling cowbird, or they fail to hatch. Vireo pairs with parasitized nests often raise the cowbird at the expense of their own young, which can greatly reduce vireo productivity and lead to population decline (Laymon, 1987; Kus, 2002; Kus and Whitfield, 2005). Cowbirds are native to the Great Plains and began arriving in southern California in the late 1800s with the arrival of settlers and their livestock. By the 1920s, cowbird populations had increased and spread through much of the vireo breeding range, with the expansion of agriculture and intensive cattle production (Laymon, 1987; Goguen and Mathews, 1999).

A potential new threat to Least Bell's Vireo is the invasion of the Kuroshio and polyphagous shot hole borers (Euwallacea sp.) into native riparian habitats in southern California (Howell and Kus, 2018; University of California Agriculture and Natural Resources, 2018a). These ambrosia beetles are native to Southeast Asia. The polyphagous shot hole borer was first detected in Los Angeles County in 2003 and has rapidly expanded into Orange, Riverside, San Bernardino, and Ventura Counties (University of California Agriculture and Natural Resources, 2018b). The Kuroshio shot hole borer was first detected in 2015 in the Tijuana River Valley and is spreading in San Diego County (University of California Agriculture and Natural Resources, 2018b). There are also a few isolated occurrences of Kuroshio shot hole borer in Orange, Los Angeles, Santa Barbara, and San Luis Obispo Counties. These beetles form an association with Fusarium fungal species causing a disease complex called Fusarium dieback, which can kill reproductive host trees of many species (64 tree species documented for polyphagous and 15 for Kuroshio; University of California Agriculture and Natural Resources, 2018b). Both beetle species invade willows and other riparian tree species, which causes extensive mortality (Boland, 2016; University of California Agriculture and Natural Resources, 2018b). In the Tijuana River Valley, a total of 355,510 willows ( 88 percent) were infested during 2015-2017 (Boland, 2017). Dead trees resprouted in 2017, which provided potential breeding habitat for vireos (Howell and Kus, 2018). The Tijuana River Valley is a key Least Bell's Vireo population in the U.S. Fish and Wildlife Service (USFWS) draft recovery plan (U.S. Fish and Wildlife Service, 1998). Shot hole borer invasion also is occurring in riparian habitats supporting other key Least Bell's Vireo populations and metapopulations in San Diego, Orange, and Ventura Counties (University of California Agriculture and Natural Resources, 2018a).

Least Bell's Vireo is a covered species in 17 Natural Community Conservation Plans and Habitat Conservation Plans developed during the last 23 years (California Department of Fish and Wildlife, 2018). These plans include conserving lands and implementing specific management objectives to protect and enhance Least Bell's Vireo populations. Habitat protection, enhancement, and restoration, along with brown-headed cowbird population management, have proven effective in increasing the size and distribution of Least Bell's Vireo populations (Kus, 1998, 2002; Kus and Whitfield, 2005). By 2005, the California population had increased nearly tenfold since the time of listing to 2,968 territories (U.S. Fish and Wildlife Service, 2006). This population growth has been tempered during extreme drought years by declines in nesting effort, productivity, and breeding success (Kus and others, 2017). Vireo population growth has been especially high in San Diego, Orange, Riverside, and Ventura Counties (U.S. Fish and Wildlife Service, 2006; Kus and others, 2017).

In addition to an increase in population size, there has been a range expansion of the Least Bell's Vireo into areas where it was previously extirpated. One to a few individuals or breeding pairs have shown up sporadically in Kern, Monterey, San Benito, Stanislaus, Yolo, and San Bernardino Counties (U.S. Fish and Wildlife Service, 2006). In 2005, the first documented breeding since the 1950s was confirmed for a single pair in the San Joaquin Valley (Howell and others, 2010). Breeding also was confirmed for a single pair at the same site in 2006 and unsuccessfully attempted by a single female in 2007.

The draft recovery plan (U.S. Fish and Wildlife Service, 1998) calls for habitat protection and restoration and brown-headed cowbird management at important riparian areas to facilitate population increase and expansion into historic breeding habitat. Specific recovery criteria (U.S. Fish and Wildlife Service, 1998) include:

Criterion 1. Stable or increasing populations in 11 key population and metapopulation units (these are within San Diego, Orange, Riverside, Los Angeles, Ventura, and Santa Barbara Counties).

Criterion 2. Stable or increasing populations in the 14 key population and metapopulation units that include 11 units in Criterion 1, plus 3 additional population and metapopulation units (Salinas River population, San Joaquin metapopulation, and Sacramento Valley metapopulation) that represent full expansion into the historic range.

Criterion 3. Threats are eliminated so that the 14 key Least Bell's Vireo populations and metapopulations are capable of persisting without intensive human intervention or management commitments to control threats from cowbird parasitism and habitat degradation in perpetuity. 
Recovery actions are being planned and implemented by the U.S. Fish and Wildlife Service (USFWS) and partners throughout the vireo's current range. The next steps are to assess habitat suitability and management potential throughout the vireo's historic range to identify and prioritize key areas for recovery. This process will entail conducting surveys to determine vireo occupancy, habitat conditions, and threats, such as from cowbird parasitism and shot hole borer Fusarium dieback. Knowledge of the location and extent of suitable vireo habitat will allow managers to focus conservation effort on sites that facilitate recolonization of the historic range through expansion of source populations in southern California. This Least Bell's Vireo habitat modeling project was funded by the National Fish and Wildlife Foundation and the Bureau of Land Management to facilitate these recovery actions.

The goal of our project was to develop a statewide habitat suitability model for Least Bell's Vireo in California by using the partitioned Mahalanobis $\mathrm{D}^{2}$ modeling approach. We followed methods that have been successfully used to model habitat for many species, including federally listed species (for example, Rotenberry and others, 2006; Preston and others, 2008; Barrows and Murphy-Mariscal, 2012; Knick and others, 2013).

This habitat model will help achieve Least Bell's Vireo recovery goals (U.S. Fish and Wildlife Service, 1998), and it will help managers meet the objectives of distinguishing specific areas to survey for new vireo occurrences, characterize important vireo-habitat relationships at the landscape-scale, and identify areas that may benefit from habitat management. The habitat suitability model will allow proactive identification and evaluation of areas where suitable vireo habitat is vulnerable to invasion by Fusarium dieback and allow greater coordination of regional efforts to control this disease complex (Eskalen and others, 2019).

\section{Methods}

\section{Study Area}

We modeled two geographic areas: the current range in southern California and the entire state of California, including the current and historic range (fig. 1). The historic and current ranges are generalized from boundaries delineated in the draft recovery plan (U.S. Fish and Wildlife Service, 1998). We expanded the current range in southern California to include some areas previously classified as historic but that support post-1990 vireo observations used for modeling. The modeled study areas were clipped to riparian vegetation types known or hypothesized to support Least Bell's Vireo and buffered $500 \mathrm{~m}$ by other land cover types.
The current southern California range is where Least Bell's Vireo populations have persisted and grown since the species was listed in 1986. It extends from southern Ventura County south to the international border with Mexico and from the Pacific coastline east into western San Bernardino and Riverside Counties and the eastern border of San Diego County. The California study area includes the current range and the historic range along the central coast and through the San Joaquin and Sacramento Valleys. The California study area also includes riparian areas where there are no historic or current Least Bell's Vireo records, including the northern coast and higher elevations in mountains surrounding the San Joaquin and Sacramento Valleys.

\section{Data}

\section{Least Bell's Vireo Data}

We developed models for the southern California current range using vireo locations from a variety of sources recorded from 1990 to 2018. We compiled Least Bell's Vireo digital data collected by the U.S. Geological Survey (USGS) and other agencies. The USGS also maintains a database of biologist reports submitted to the USFWS that detail Least Bell's Vireo survey results. We identified and filled in data gaps by digitizing locations from several reports for the Santa Clara River and desert populations in San Diego County. We selected vireo records for 13 years with the most spatially comprehensive location data reflecting average $(1997,2004$, 2010, 2016), below average (1990, 2007, 2012, 2013, 2018) and above average $(1993,2005,2011,2017)$ rainfall years. This approach allowed us to evaluate normalized difference vegetation index (NDVI) values associated with vireo locations across environmental conditions and time.

For each rainfall category, we selected 3-4 years of spatially precise southern California location data for the 1990-2013 period. We created a 150-meter (m) grid of the study area with ArcGIS 10.5 software. We processed data to randomly select and remove spatially redundant vireo locations at each $150-\mathrm{m}$ cell. We divided this overall dataset into a randomly selected model construction dataset consisting of 2,270 observation records (70 percent) and used the remaining 972 observations ( 30 percent) as a random evaluation dataset (table 1; fig. 2).

We used the most recent survey data reflecting different annual rainfall conditions to evaluate model performance, especially for those models including NDVI variables. These data included 2016 (average rainfall), 2017 (above average rainfall), and 2018 (below average rainfall) evaluation datasets with $610,1,066$, and 882 observations, respectively (table 1; fig. 2). 


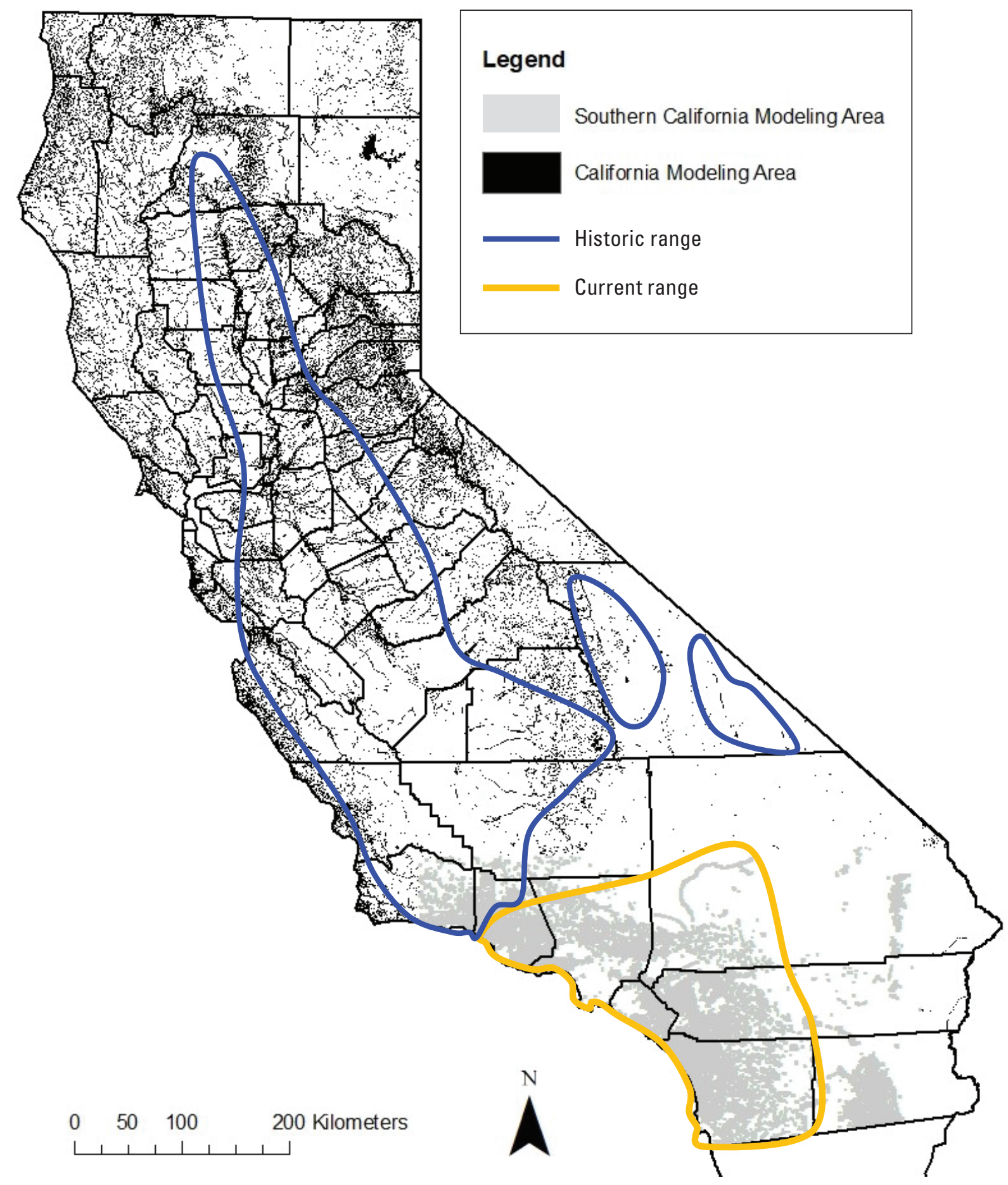

Figure 1. California and southern California study areas with modeling extents defined by riparian vegetation communities potentially used by Least Bell's Vireos and buffered 500 meters by other types of land cover. The California modeling area also includes the southern California modeling extent. Approximate boundaries of the historic range are indicated by the blue polygons and the current range by an orange polygon. Some recent vireo observations have been made within the historic range. 
Table 1. Least Bell's Vireo location datasets used for habitat modeling with sources of observations, total number of observations per dataset, and how datasets were used in model construction and evaluation in the current and historic ranges.

[HSI, habitat similarity index; AUC, area under the curve; m, meter]

\begin{tabular}{|c|c|c|c|c|}
\hline Dataset use & $\begin{array}{c}\text { Dataset and observation } \\
\text { years }\end{array}$ & Sources & $\begin{array}{c}\text { Number of } \\
\text { observations }\end{array}$ & $\begin{array}{l}\text { Evaluation } \\
\text { metrics }\end{array}$ \\
\hline $\begin{array}{l}\text { Model construction in } \\
\text { current range }\end{array}$ & $\begin{array}{l}\text { 1990-2013 observations } \\
\text { randomly selected } \\
\text { (70 percent) }\end{array}$ & $\begin{array}{c}\text { Anza Borrego State Park } \\
\text { Bloom Biological } \\
\text { Bon Terra Consulting } \\
\text { California Natural Diversity Database } \\
\text { Center for Natural Lands Management } \\
\text { Davenport Biological Services } \\
\text { Friends of the Santa Clara River } \\
\text { Griffith Wildlife Biology } \\
\text { Ogden Environmental } \\
\text { San Bios } \\
\text { Santa Ana Watershed Association } \\
\text { U.S. Geological Survey } \\
\text { Western Riverside Conservation Authority }\end{array}$ & 2,270 & Median HSI \\
\hline $\begin{array}{l}\text { Model selection/ } \\
\text { evaluation in current } \\
\text { range }\end{array}$ & $\begin{array}{l}\text { 1990-2013 observations } \\
\text { randomly selected } \\
(30 \text { percent })\end{array}$ & $\begin{array}{c}\text { Anza Borrego State Park } \\
\text { Bloom Biological } \\
\text { California Natural Diversity Database } \\
\text { Center for Natural Lands Management } \\
\text { Friends of the Santa Clara River } \\
\text { Griffith Wildlife Biology } \\
\text { Ogden Environmental } \\
\text { San Bios } \\
\text { Santa Ana Watershed Association } \\
\text { U.S. Geological Survey } \\
\text { Western Riverside Conservation Authority }\end{array}$ & 972 & Median HSI \\
\hline $\begin{array}{l}\text { Model selection/ } \\
\text { evaluation in current } \\
\text { range }\end{array}$ & $\begin{array}{l}2016 \text { observations } \\
\text { (average rainfall) }\end{array}$ & $\begin{array}{c}\text { California Natural Diversity Database } \\
\text { Santa Ana Watershed Association } \\
\text { U.S. Geological Survey }\end{array}$ & 610 & Median HSI \\
\hline $\begin{array}{l}\text { Model selection/ } \\
\text { evaluation in current } \\
\text { range }\end{array}$ & $\begin{array}{c}2017 \text { observations (above } \\
\text { average rainfall) }\end{array}$ & $\begin{array}{c}\text { California Natural Diversity Database } \\
\text { Orange County Water District } \\
\text { RECON } \\
\text { Santa Ana Watershed Association } \\
\text { U.S. Geological Survey }\end{array}$ & 1,066 & Median HSI \\
\hline $\begin{array}{l}\text { Model selection/ } \\
\text { evaluation in current } \\
\text { range }\end{array}$ & $\begin{array}{c}2018 \text { observations (below } \\
\text { average rainfall) }\end{array}$ & U.S. Geological Survey & 882 & Median HSI \\
\hline $\begin{array}{l}\text { Model selection/ } \\
\text { evaluation in current } \\
\text { range }\end{array}$ & $\begin{array}{l}\text { Presence-absence: } \\
\text { Presence points from } \\
\text { random, 2016, 2017, } \\
\text { and } 2018 \text { evaluation } \\
\text { datasets; absence points } \\
\text { randomly selected } \\
\text { from grid of riparian } \\
\text { vegetation buffered } \\
500 \mathrm{~m}\end{array}$ & See previous list of dataset sources & $\begin{array}{l}\text { 7,060: } \\
\text { 3,530 presences; } \\
\text { 3,530 pseudo- } \\
\text { absences }\end{array}$ & AUC \\
\hline $\begin{array}{l}\text { Model evaluation in } \\
\text { historic range }\end{array}$ & 1877-2016 observations & California Natural Diversity Database & $\begin{array}{c}52 \text { observations at } \\
47 \text { sites }\end{array}$ & $\begin{array}{l}\text { Qualitative } \\
\text { assessment }\end{array}$ \\
\hline $\begin{array}{l}\text { Model evaluation in } \\
\text { historic range }\end{array}$ & 2012-2019 observations & eBird & $\begin{array}{c}117 \text { observations } \\
\text { at } 20 \text { sites }\end{array}$ & $\begin{array}{l}\text { Qualitative } \\
\text { assessment }\end{array}$ \\
\hline
\end{tabular}




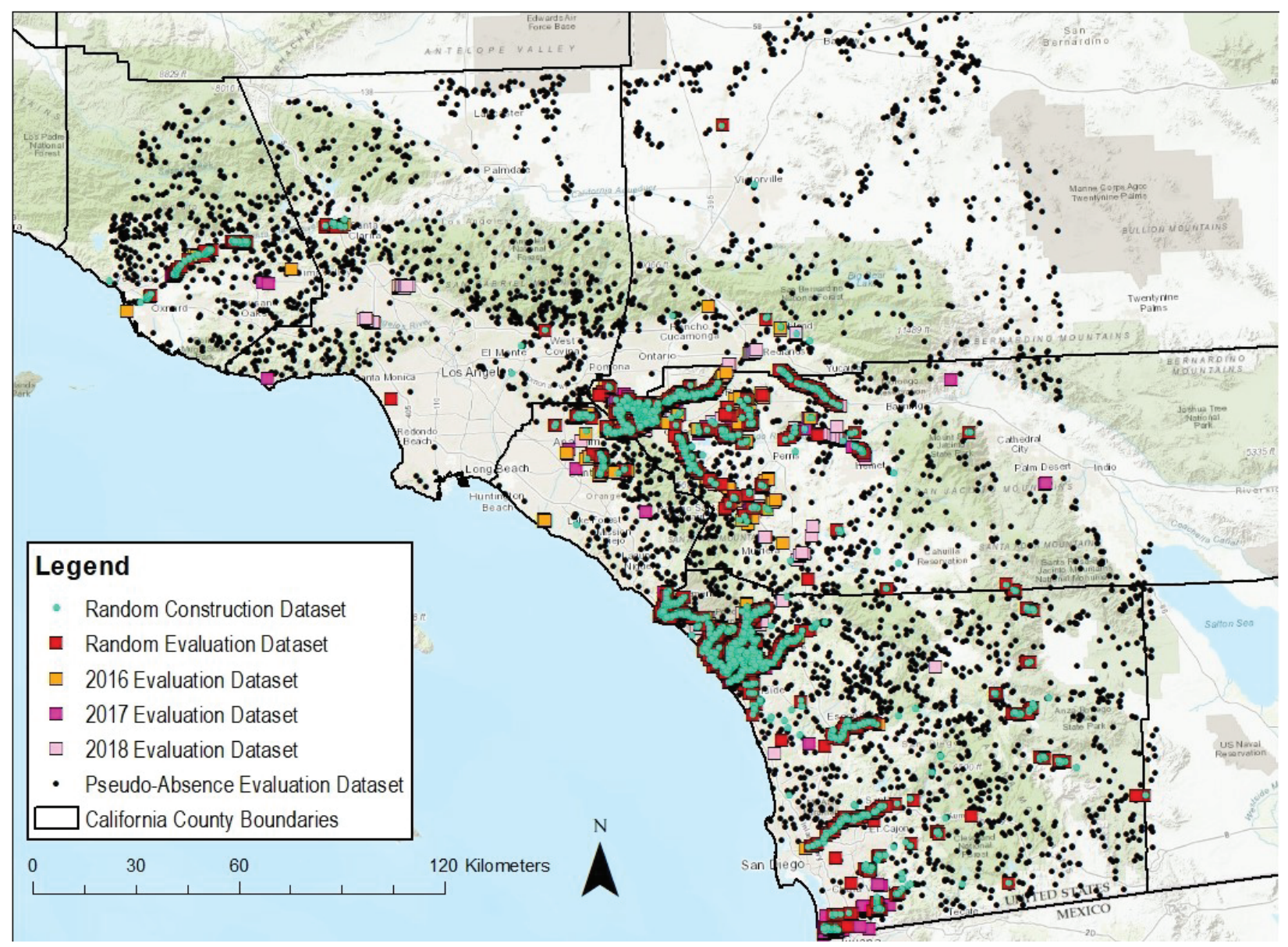

Figure 2. Southern California Least Bell's Vireo spatially distinct location datasets for constructing alternative models and evaluating performance. Pseudo-absence locations are randomly selected from the environmental grid for riparian vegetation buffered 500 meters.

We created a presence and pseudo-absence dataset to assess how well models distinguished between areas where vireos occur and where they have not been detected. We combined the random evaluation dataset with 2016, 2017, and 2018 evaluation datasets for a combined 3,530 presence points. We randomly selected an equivalent number $(3,530)$ of pseudo-absence points from the grid of points encompassing riparian vegetation buffered $500 \mathrm{~m}$ in the vireo's current range. By selecting pseudo-absences from environmental conditions similar to where Least Bell's Vireo occur (within the current range and in buffered riparian habitat), we avoided overpredicting suitable habitat (Chefaoui and Lobo, 2008). Selecting pseudo-absences from environmental regions (in other words, non-riparian habitat) farther from the vireo environmental optimum can lead to inflated accuracy scores and overprediction of suitable habitat.

We extracted values for environmental variables from the grid cell (see later in the report) at each southern California vireo location in the construction and evaluation datasets. These data were used to develop and assess habitat models for the current range.

We created vireo location datasets to qualitatively evaluate model performance in the historic range. These datasets consisted of historical (1877-1989) and recent (detected since 1990) California Natural Diversity Database (CNDDB; California Natural Diversity Database, 2018) observations and recent eBird (eBird, 2019) observations (table 1; fig. 3). Many of the recent records represent multiple sightings of the same bird(s) in the same year or bird(s) at the same site over different years. Most historic records and some recent observations are of low spatial accuracy, representing general survey sites and not specific bird locations. We used aerial photo interpretation and CNDDB and eBird information to evaluate current land use (developed versus natural vegetation) at each site and categorize vireo records as extirpated, potentially extirpated, and extant/potentially extant. 


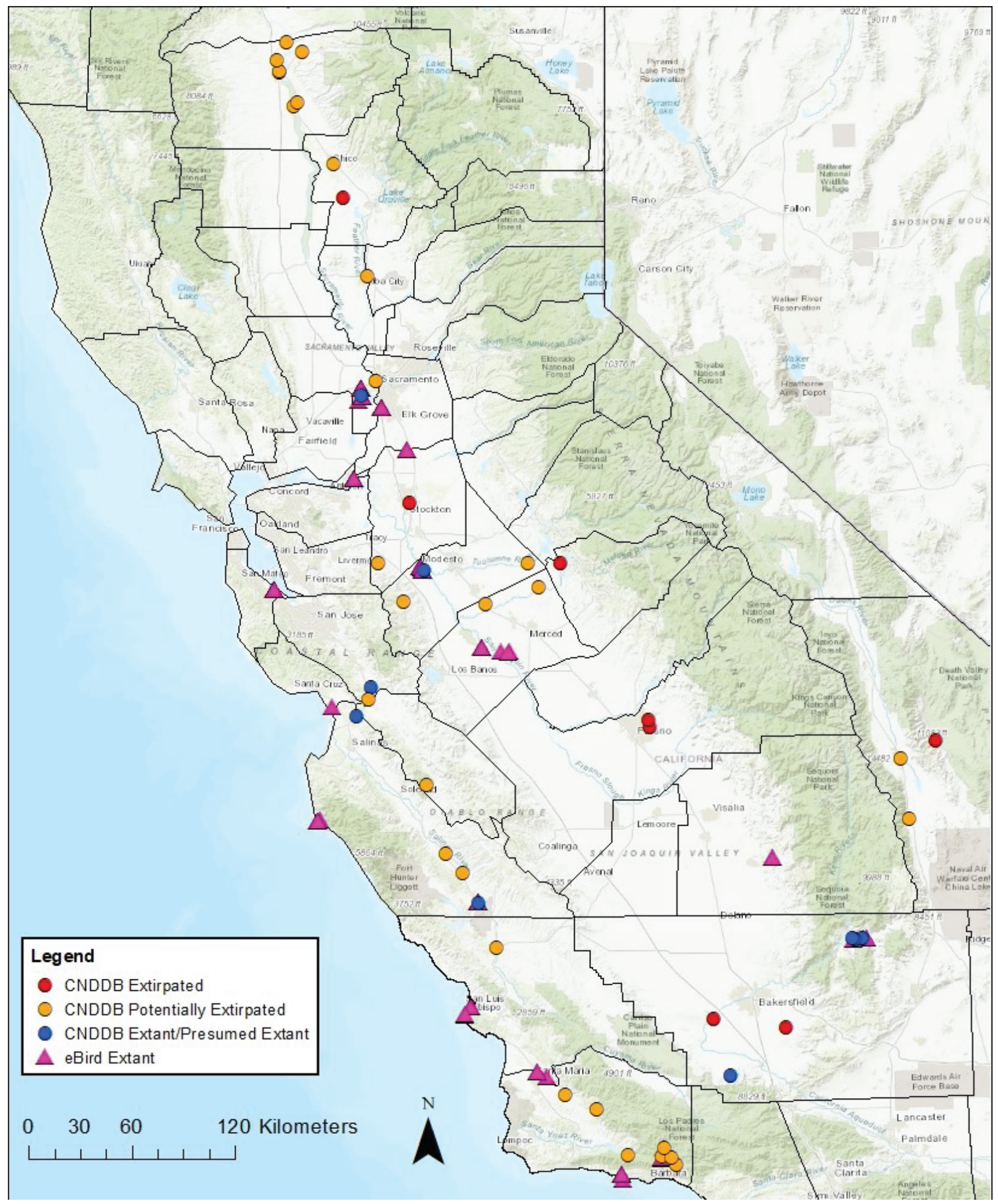

Figure 3. California Least Bell's Vireo California Natural Diversity Database (CNDDB) historic and recent observations and eBird recent observations used to qualitatively evaluate model predictions in the historic range. Vireo locations are classified as extirpated, potentially extirpated and extant/potentially extant. 


\section{Environmental Variables}

We calculated environmental variables at the center point of each 150- by 150-m grid cell using ArcGIS 10.5 software and various spatial data layers. Variables reflect various aspects of topography, climate, hydrology, and land cover (percent riparian vegetation and urbanization at $150-\mathrm{m}, 500-\mathrm{m}$, and 1-kilometer [km] scales). We calculated 28 environmental variables to use in developing alternative models (table 2). To display model predictions, we clipped each grid to selected riparian vegetation types buffered $500 \mathrm{~m}$ with adjacent land cover types.

For each 150-m grid cell, we computed median elevation, slope and topographic heterogeneity, and percent flatness. We calculated precipitation and average minimum and maximum temperatures to reflect winter (OctoberDecember), pre-breeding (January-March), and breeding (April-June) conditions. We used cumulative water deficit (CWD) to quantify water availability for vegetation across sites. Cumulative water deficit is the cumulative difference between potential evapotranspiration and actual evaporative transpiration during a specified period.

To calculate land cover, we assessed several different Geographic Information System (GIS) vegetation maps and selected the statewide Fire Resource Assessment Program (FRAP) 2015 Vegetation Map as a base map for California (California Department of Forestry and Fire Protection, 2015). This map best depicted riparian vegetation at Least Bell's Vireo locations. Through previous modeling efforts, we discovered mapping and classification inaccuracies, as FRAP merges multiple vegetation maps across the state with differing classification schemes, spatial scales and mapping years, many of which are outdated. To improve riparian vegetation mapping, we cross-walked and merged FRAP with six recent and detailed regional vegetation maps for southern California (table 2). We used the Klausmeyer and Howard (2016) groundwater dependent ecosystems map for California to capture riparian areas not mapped with the other source layers. From each vegetation mapping source, we added riparian vegetation communities used by Least Bell's Vireos into one riparian habitat layer to include in our modeling grid (appendix 1, table 1.1).

To better characterize the historic range, we used the same or similar vegetation communities identified for southern California and added in new community classifications that include plant species used by vireos or that have similar species and structure. For the merged vegetation map, we selected 260 vegetation categories across the 8 map sources (appendix 1, table 1.1). Many of these categories are redundant classifications among the mapping sources or are slight variations of a similar vegetation or hydrological classification. These selected riparian vegetation types are merged into one "riparian" class, independent of original classification, and used to approximate riparian vegetation potentially used by Least Bell's Vireos across California. The selected riparian vegetation communities form the riparian modeling grid and are buffered $500 \mathrm{~m}$ by other landcover types. We calculated percent riparian vegetation at each grid point for local (150-m) and landscape (500-m, 1-km) scales. In addition to riparian vegetation, we calculated urban land use at these multiple scales.

We employed Landsat NDVI remote imagery to calculate NDVI variables reflecting growing vegetation across the landscape. For each vireo observation, we calculated NDVI variables for the year of each observation to develop the model construction and evaluation datasets. We selected 2017, an above average rainfall year, to calculate NDVI variables for the southern California and California modeling grids. Normalized difference vegetation index variables are calculated as means, maximums, and percentages of pixels with a minimum specified value at the $150-\mathrm{m}$ and $500-\mathrm{m}$ spatial scales (table 2).

\section{Modeling Approach}

Niche models use species occurrence data and environmental variables calculated in GIS to identify suitable habitat (Guisan and Zimmerman, 2000; Elith and others, 2006). We used the partitioned Mahalanobis $D^{2}$ modeling approach to predict suitable habitat across the current and historic range of the Least Bell's Vireo. Predicting suitable habitat in a novel environment where there is a lack of species records is challenging because environmental conditions can differ substantially from conditions where the species occurs. The partitioned Mahalanobis $\mathrm{D}^{2}$ technique, unlike most modeling algorithms, is designed to predict habitat suitability in areas not included in a sample of species locations, in dynamic landscapes, and under novel conditions (Knick and Rotenberry, 1998; Rotenberry and others, 2002). This type of approach is intended to model large areas of California historically supporting vireos, but from where they have been extirpated and there is little or no recent location data. Particularly challenging is the situation where the historic range in northern and central California differs in many environmental characteristics (for example, climate, topography, vegetation communities) from the currently occupied range in southern California. This difference in characteristics complicates predicting suitable habitat for the vireo in the historic range based on current habitat relationships in southern California. 
Table 2. Description of variables included in the southern California and California environmental grids to create alternative Least Bell's Vireo models.

[m, meter; USGS, U.S. Geological Survey; =, equal to; BCM, Basin Climate Mode; mm, millimeters; km, kilometers; NDVI, normalized difference vegetation index; >, greater than]

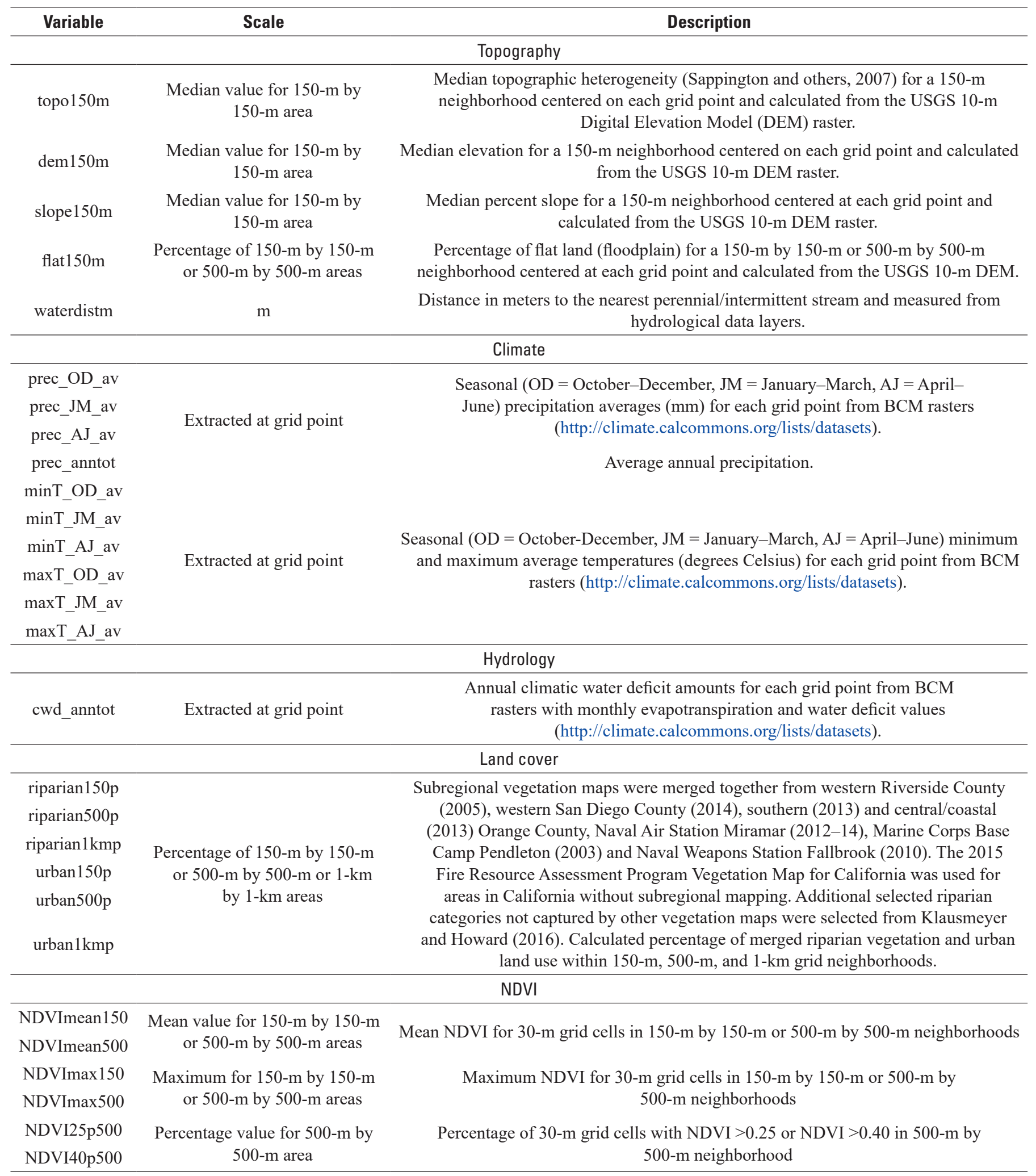


Mahalanobis $\mathrm{D}^{2}$ is the standardized difference between the multivariate mean for environmental variables calculated for the set of species observations and the values of these variables at each grid point across the landscape. The more similar the environmental conditions at each grid point in the landscape are to species occurrences, the higher the habitat similarity index (HSI) value for that point. The HSI ranges from 0 (least similar or unsuitable) to 1.0 (most similar or suitable). Using principal components analysis, Mahalanobis $\mathrm{D}^{2}$ can be partitioned into separate components representing independent relationships between the species distribution and environmental variables. Model partitions with smaller eigenvalues represent environmental variables varying the least at species occurrences and can be associated with limiting factors (Rotenberry and others, 2002, 2006; Knick and others, 2013). Variables that vary widely are not as informative because they are not restrictive of the species distribution. Partitioning environmental relationships and focusing on those that are most consistent where vireos occur improves modeling of limiting conditions in novel or dynamic environments.

Our approach to developing a habitat model for the historic range of Least Bell's Vireo in California consisted of the following steps:

1. Compile spatially distinct and precise digital observations for Least Bell's Vireos in the current range in southern California to create model construction and evaluation datasets.

2. Develop a southern California 150-m scale grid and calculate environmental variables at each grid point in the center of a $150-\mathrm{m}$ grid cell including measures of topography, climate, hydrology, vegetation, and NDVI. For each vireo observation, extract environmental variable values from the $150-\mathrm{m}$ grid cell in which they occur.

3. Use Partitioned Mahalanobis $\mathrm{D}^{2}$ to develop alternative models with different combinations of environmental variables hypothesized to be important components of vireo habitat in southern California. Calculate HSI values for all model partitions from 0 (low habitat suitability) to 1 (high suitability) for the model evaluation datasets.

4. Evaluate model-partition predictions with the southern California evaluation datasets using median HSI values and area under the curve (AUC) to identify the combinations of variables that best predict vireo occurrence. Select a set of best performing model partitions for southern California.

5. Develop a 150-m scale environmental grid (as mentioned earlier) for all of California (clipped to riparian vegetation buffered $500 \mathrm{~m}$ ).
6. Use the subset of best performing model partitions for southern California to predict suitable habitat across California. Qualitatively evaluate model predictions across the historic range using aerial photography and historical and recent vireo observation records, typically of lower spatial precision. Quantify environmental conditions in the vicinity of vireo observations in the historic range.

7. Select the best performing model partition for both southern California and California study areas. Use this model partition to quantify potentially suitable habitat across California.

\section{Model Selection and Evaluation}

\section{Model Construction}

We developed alternative models with various combinations of environmental variables reflecting hypothesized Least Bell's Vireo habitat relationships. We developed and compared comprehensive exploratory models with full complements of different variables describing topography, climate seasonality, hydrology, and percent riparian and urbanization at local to landscape scales.

We selected variables based on what is known about Least Bell's Vireo habitat requirements and our previous experience modeling the vireo and other species. We selected topographical variables thought to describe vireo habitat in southern California, including flat floodplains, shallow slopes, and lower elevations along the coast and inland valleys and foothills. We hypothesized vireos cluster near stream and river channels and calculated distance to water.

We computed average seasonal climate conditions that may influence habitat suitability across sites. We calculated precipitation and average minimum and maximum temperatures to reflect winter, pre-breeding, and breeding conditions. Average winter and pre-breeding climates can vary substantially across sites and affect phenology and growth of vegetation during early spring when migrating vireos return to choose breeding territories. In contrast, typical climate conditions during the breeding season's incubation and chick rearing phases may have the greatest influence on habitat suitability. Finally, annual rainfall may be more important than seasonal precipitation variables because it includes winter and pre-breeding season influences on vegetation phenology and growth and affects breeding season conditions. It was anticipated that average annual minimum and maximum temperature extremes would be less important because migratory vireos are absent from California in winter months when temperatures are coldest and have usually finished breeding by the time summer temperatures are highest. Cumulative water deficit is effective at describing plant distributions in arid lands (Dilts and others, 2015). We hypothesized CWD could be an important habitat predictor for vireo habitat in more arid portions of the range. 
The partitioned Mahalanobis $\mathrm{D}^{2}$ modeling technique can accommodate correlated variables as it partitions out relationships between variables into independent components (Rotenberry and others, 2002). We typically selected one of two highly redundant variables describing the same aspect of the environment to include in our universe of variables for modeling (for example, median elevation for $150-\mathrm{m}$ scale neighborhood compared with elevation extracted at a grid point, $r=0.99$ ). However, for two correlated variables that reflect different aspects of habitat relationships (for example, elevation and minimum temperature), we kept both variables to include in our models and relied on the partitions to sort out important and independent environmental relationships.

We did not run all combinations of variables or create one model with all variables included. Instead, we started with a set of comprehensive models to compare the effects of climate seasonality and land cover scale on model performance. These comprehensive models included topographic variables, climate variables for a particular season (winter, spring, summer and no season), climatic water deficit, and local- and landscape-scale land cover variables. We compared among these comprehensive models to see which variables within the various categories best predicted suitable habitat. We selected a few of the better performing models and then tested whether different NDVI variables improved performance. Finally, we removed variables from these more comprehensive models to see if simpler models performed as well.

We divided southern California into 10 sampling regions because of spatial unevenness in Least Bell's Vireo location data. Some areas, such as San Diego County, with large concentrations of vireo observations, could introduce spatial bias into the model. We divided southern California into geographic units reflecting similar environmental conditions and used bootstrapping to resample from the model construction dataset (Knick and others, 2013). We randomly selected 70 observations from each region for a total of 700 observations selected from the 2,270 observations in the construction dataset. We used this subset of observations to create model partition output for a specific set of environmental variables. We repeated this process 1,000 times to obtain different combinations of observations to construct the model with each iteration. We model-averaged the results from sampling iterations to create an overall model with partitions for that particular set of variables.

\section{Quantitative Model Evaluation in the Current Range of Southern California}

The next step was to compare performance among these constructed model partitions in predicting suitable habitat in the current range in southern California. We used the random 2016, 2017, and 2018 evaluation datasets and the combined presence-absence dataset of 3,530 vireo occurrences and 3,530 pseudo-absence points (table 1). For every model partition, we calculated HSI predictions for vireo presence and pseudo-absence points ranging from Very High $=0.75-1.00$; High $=0.50-0.74$; and Low to Moderate $=0-0.49$. Suitable habitat is identified as HSI greater than or equal to 0.5 for vireo locations and the modeling grid points. We calculated AUC values from a Receiver Operating Curve to determine how well models distinguish between the combined presence points and the pseudo-absence points (Fielding and Bell, 1997). Area under the curve values of 0.7 indicate the model partition does a good job discriminating presences from pseudo-absences, whereas AUC values greater than 0.9 show excellent separability. We selected a set of top performing calibration model partitions based on median HSI values for the evaluation datasets and the AUC results. We selected a subset of high performing models for further assessment in the historic range.

\section{Model Evaluation in the Historic Range}

\section{Qualitative Evaluation}

We utilized top performing southern California model partitions to predict Least Bell's Vireo habitat suitability across the historic range in California. We calculated habitat suitability predictions for each grid point in the California riparian modeling grid. We visually evaluated each model partitions map to see if suitable habitat was predicted in the historic range in areas known to previously support Least Bell's Vireos. We then closely assessed habitat suitability predictions at historic observations and recent sightings of recolonizing birds. We used aerial photography to determine current conditions at each observation location, including level of development and how well the selected riparian vegetation mapping appeared to reflect conditions on the ground. We classified location accuracy for each observation based on observation year, spatial resolution information, and location descriptions in the dataset. We classified an observation as extirpated if the location and surrounding area were developed for urban or agricultural uses. We assigned an observation as potentially extirpated if there were no observations since 1990 but the location remains largely undeveloped. For locations where vireos have been observed since 1990, we classified them as extant or potentially extant if the area was undeveloped. We selected one model partition as best performing based on our qualitative assessment of model predictions in the historic range. 


\section{Quantitative Evaluation}

We quantitatively compared environmental conditions in the historic and current ranges and at vireo locations to better understand vireo habitat relationships. We calculated means and standard deviations (std) for all environmental variables at Least Bell's Vireo locations in the model construction dataset in the current range and at modeling grid points throughout the historic and current ranges. Using the selected best-performing model, we calculated means and std for environmental variables included in the model for suitable and unsuitable habitat across the California modeling grid and for the vireo model construction dataset. We calculated a range in values for the construction dataset using the mean plus or minus $1 \mathrm{std}$ and mean plus or minus 2 std to represent 65 and 95 percent of vireo observations, respectively. Using the environmental modeling grid, we selected an "observation area" surrounding each historic and recent vireo observation in the historic range. The observation area characterizes environmental conditions at each vireo location and averages 150 grid points in size (about 340 hectares [ha] or 840 acres) including streams, rivers, and buffered areas nearest the observation. For each observation area, we calculated means and std for the environmental variables included in the selected model.

\section{Using the Model to Assess Suitable Habitat}

We used county and hydrologic unit code (HUC) 8 boundary layers in ArcGIS to quantify the amount of suitable Least Bell's Vireo habitat predicted by the top performing model in counties and watersheds in current and historic ranges across southern California. We determined how much suitable habitat is conserved by using the California Protected Areas Database (California Protected Areas Database, 2019). We also compiled detection histories describing the general prevalence or absence of recent (greater than or equal to 1990) and historic (less than 1990) Least Bell's Vireo observations in each watershed and presence versus lack of detections for each county. We also included Bell's vireo observations in California that were unassigned to a subspecies to expand our detection histories for HUC 8 watersheds. We did not evaluate or quantify environmental conditions for these unassigned observations. We excluded observations of other Bell's vireo subspecies from our detection histories. We also calculated the approximate amount of suitable habitat for populations and metapopulations in the historic range identified in the draft recovery plan as critical to vireo recovery (U.S. Fish and Wildlife Service, 1998).

\section{Results}

\section{Southern California and California Environmental Grids}

The southern California 150-m scale environmental grid consists of 3,794,874 grid points across all landcover types. The modeling grid is reduced to 437,483 grid points when clipped to selected riparian vegetation communities and buffered $500 \mathrm{~m}$ by other landcover types. This latter grid is used to display model predictions for southern California. The 150 -m scale California modeling grid has 2,534,929 points and includes selected riparian vegetation communities buffered $500 \mathrm{~m}$.

\section{Southern California Habitat Modeling Results}

We created and evaluated 35 habitat models for Least Bell's Vireo in the current range in southern California. In appendix 2, table 2.1 displays model variables and evaluation results for the 20 top performing models. These models performed similarly in predicting suitable habitat in southern California. They have high AUC values (greater than 0.90) and relatively high median HSI values for the random model construction and evaluation datasets, although values for the 2016, 2017, and 2018 evaluation datasets vary among models. For all models, the best performing partition was partition 1, or the full model, and included contributions from all variables. In these cases, lower model partitions poorly predicted habitat suitability, indicating that most variables included in the model were not limiting habitat relationships in the current range. Generally, these lower partitions, as reflected by eigenvector scores, were dominated by relationships between variables representing climate, topography, and urban land use. Higher partitions represented relationships between percent riparian and other variables, particularly flat land and slope. Among the simpler models without climate and urbanization variables, lower partitions included high eigenvector scores for riparian, topography, and hydrology. 
The best performing models included consistent combinations of variables describing topography and percent riparian at the local scale $(150 \mathrm{~m})$. Adding variables that describe climate, urbanization, or NDVI did not increase AUC values, although there were small changes in median HSI values among models, depending on the evaluation dataset. This lack of improvement in model performance by adding variables is illustrated by model R1-P1 with the highest AUC of 0.932 (appendix 2, table 2.1). The model included topography, winter climate, percent urban, and percent riparian at the local $(150 \mathrm{~m})$ scale, distance to water, and annual CWD. In contrast, the next highest performing model for southern California, model R29-P1, with an AUC of 0.931 , had only 5 of the 12 variables in Model 1 . These variables were slope, local-scale riparian and flatness, distance to water, and annual CWD. The simpler model did not change model performance as reflected by the AUC scores, although there were some differences in median HSI values among the evaluation datasets.

\section{Selected Model Performance and Environmental Conditions in California's Historic Range}

For the subset of top performing models, we created Least Bell's Vireo habitat suitability maps for the California modeling area. Most top-performing model partitions developed for the current range predicted no suitable habitat in the historic range. Of the remaining models, all but one were overly restrictive and predicted limited amounts of vireo habitat. In general, models failing to predict suitable habitat in the historic range included NDVI, climate, and hydrology variables, some of which differed substantially in value in the historic range compared to current vireo locations (table 3 ). Modeled riparian vegetation in the historic range had higher NDVI values, higher precipitation, lower minimum and maximum temperatures, and lower CWD compared to vireo locations in the model construction dataset. Average values for slope and elevation in the current southern California range were substantially higher than in the model construction dataset, reflecting mountainous habitat included in the modeling grid that is unused by vireos.

Model R30-P1 was selected as the model partition that best predicted suitable habitat in current and historic ranges across California (appendix 2, table 2.1; figs. 4, 5; Preston and others, 2019 [https://www.sciencebase.gov/ catalog/item/5dba1199e4b06957974eb763]). It ranked tenth highest in AUC values for the southern California modeling area, although the 0.007 difference between this and the top model partition (R1-P1) was negligible (appendix 2, table 2.1). Model R30-P1 did well in predicting suitable habitat in the current range at locations where vireos occur (fig. 6). It had an AUC of 0.925 and median HSI of 0.70 for randomly selected model construction and evaluation datasets. Supplementary evaluation datasets for 2016, 2017, and 2018 had median HSI values of $0.66,0.64$, and 0.63 , respectively. Model R30-P1 identified suitable habitat in the historic range across California, including areas with recent vireo locations (figs. 5, 7). Model R30-P1 was a simple model with only four variables: median slope, percent flat land and percent riparian vegetation at the $150-\mathrm{m}$ scale, and distance from water.

Table 3. Environmental variable means and standard deviations calculated for the Least Bell's Vireo model construction dataset and for the riparian modeling grids in historic and current ranges.

[Values highlighted in gray indicate historic and current range values outside 95 percent of observations in the model construction dataset (mean plus or minus 2 standard deviations [std]). Bolded text indicates variables included in the top-performing model R30-P1 predicting suitable habitat in the historic range. Abbreviation: \pm , plus or minus]

\begin{tabular}{cccc}
\hline Environmental & \multicolumn{3}{c}{ Mean $\mathbf{\text { std }}$} \\
\cline { 2 - 4 } variables & Historic range & Current range & $\begin{array}{c}\text { Construction } \\
\text { dataset }\end{array}$ \\
\hline Sample size & 601,118 & 319,443 & 2,270 \\
NDVImean150 & $0.60 \pm 0.13$ & $0.53 \pm 0.17$ & $0.50 \pm 0.13$ \\
NDVImean500 & $0.59 \pm 0.12$ & $0.53 \pm 0.16$ & $0.47 \pm 0.12$ \\
NDVImax150 & $0.92 \pm 0.08$ & $0.66 \pm 0.17$ & $0.66 \pm 0.11$ \\
NDVIMax500 & $0.96 \pm 0.05$ & $0.76 \pm 0.14$ & $0.73 \pm 0.09$ \\
dem150m & $223.56 \pm 342.74$ & $530.19 \pm 424.31$ & $140.73 \pm 163.14$ \\
slope150m & $5.89 \pm 8.81$ & $14.14 \pm 11.31$ & $\mathbf{2 . 6 5} \pm \mathbf{4 . 3 3}$ \\
topo150m & $306.57 \pm 284.54$ & $600.23 \pm 174.95$ & $400.08 \pm 257.10$ \\
riparian150p & $0.09 \pm 0.20$ & $0.08 \pm 0.19$ & $\mathbf{0 . 6 4} \pm \mathbf{0 . 3 0}$ \\
riparian500p & $0.09 \pm 0.44$ & $0.08 \pm 0.13$ & $0.44 \pm 0.26$ \\
urban150p & $0.06 \pm 0.20$ & $0.17 \pm 0.34$ & $0.10 \pm 0.20$ \\
urban500m & $0.06 \pm 0.17$ & $0.18 \pm 0.29$ & $0.17 \pm 0.21$ \\
flat150m & $0.57 \pm 0.44$ & $0.18 \pm 0.29$ & $\mathbf{0 . 6 2} \pm \mathbf{0 . 2 9}$ \\
waterdistm & $204.56 \pm 256.64$ & $257.50 \pm 296.59$ & $\mathbf{1 3 3 . 7 3} \pm \mathbf{2 3 0 . 1 4}$ \\
prec_OD_av & $163.58 \pm 74.00$ & $108.75 \pm 41.56$ & $86.48 \pm 14.94$ \\
prec_JM_av & $271.89 \pm 105.03$ & $263.11 \pm 105.15$ & $204.06 \pm 38.13$ \\
prec_AJ_av & $58.83 \pm 28.53$ & $40.64 \pm 16.05$ & $31.50 \pm 5.08$ \\
prec_anntot & $504.30 \pm 206.90$ & $424.31 \pm 162.17$ & $329.11 \pm 55.08$ \\
minT_OD_av & $6.0 \pm 1.44$ & $7.91 \pm 2.51$ & $8.65 \pm 1.10$ \\
minT_JM_av & $4.53 \pm 1.54$ & $5.80 \pm 2.56$ & $6.99 \pm 1.08$ \\
minT_AJ_av & $10.44 \pm 1.94$ & $16.03 \pm 2.76$ & $17.49 \pm 1.22$ \\
maxT_OD_av & $19.09 \pm 1.49$ & $21.60 \pm 2.41$ & $22.82 \pm 0.91$ \\
maxT_JM_av & $16.12 \pm 1.61$ & $18.39 \pm 2.61$ & $19.97 \pm 0.73$ \\
maxT_AJ_av & $26.12 \pm 2.65$ & $35.79 \pm 3.94$ & $34.50 \pm 4.05$ \\
cwd_anntot & $907.20 \pm 169.35$ & $1085.41 \pm 126.85$ & $1119.42 \pm 59.33$ \\
\hline & & & \\
\hline
\end{tabular}




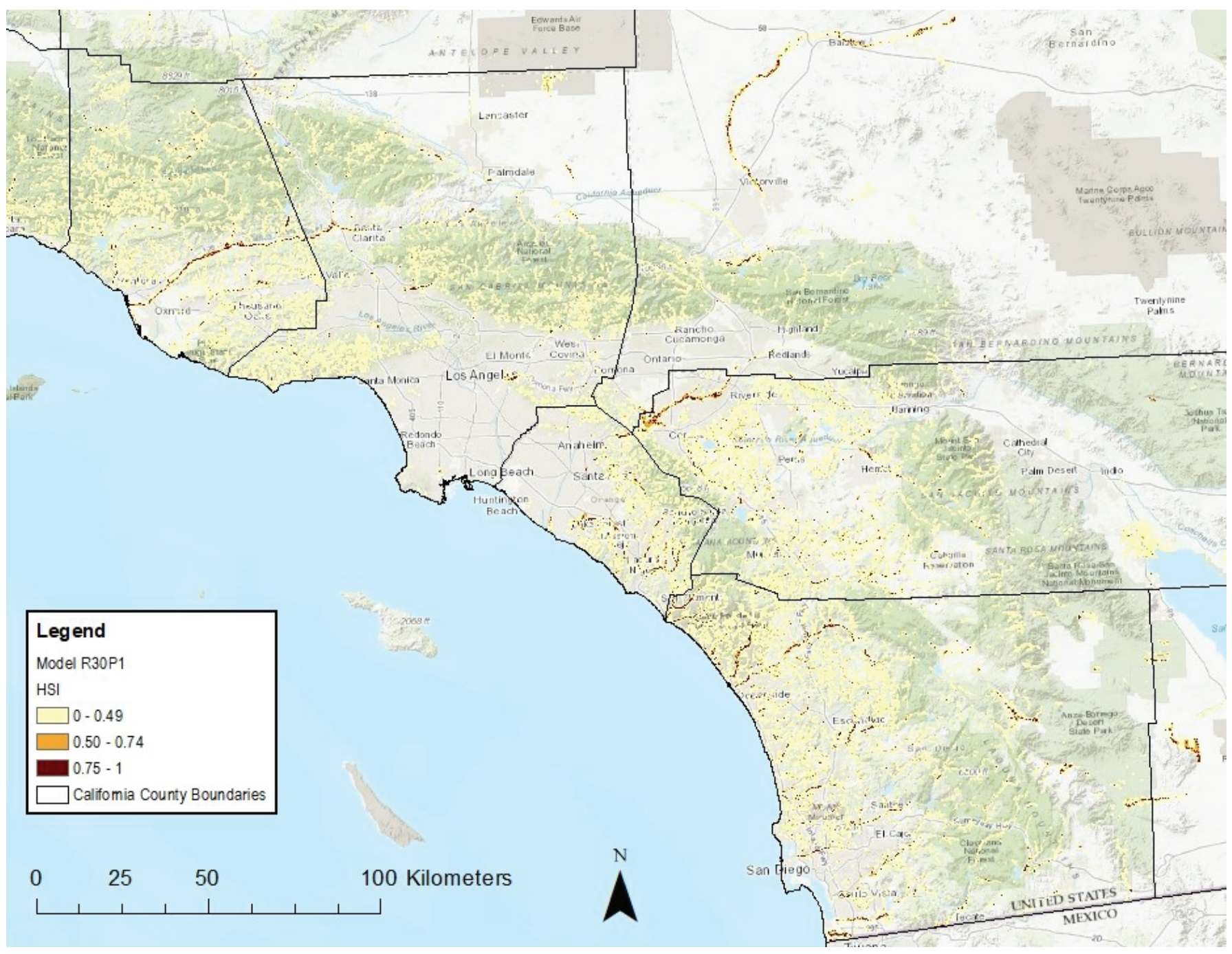

Figure 4. Model R30-P1 habitat suitability predictions for the current range in southern California. Suitable habitat is defined as habitat similarity index (HSI) greater than or equal to 0.5. Refer to data release to see map in detail (Preston and others, 2019; https://www.sciencebase.gov/catalog/item/5dba1199e4b06957974eb763). 


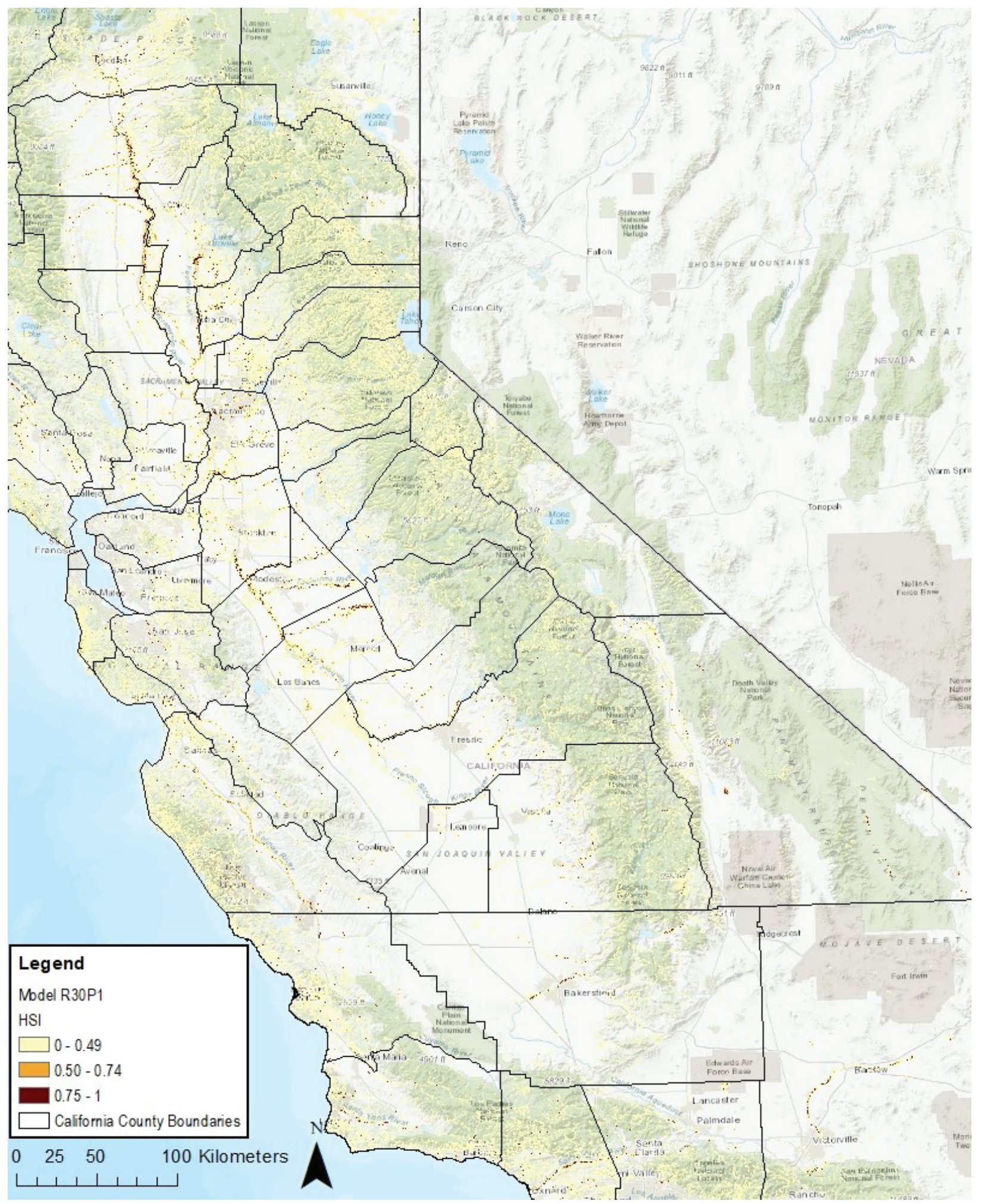

Figure 5. Model R30-P1 habitat suitability predictions for the historic range in California. Suitable habitat is defined as habitat similarity index (HSI) greater than or equal to 0.5 . 


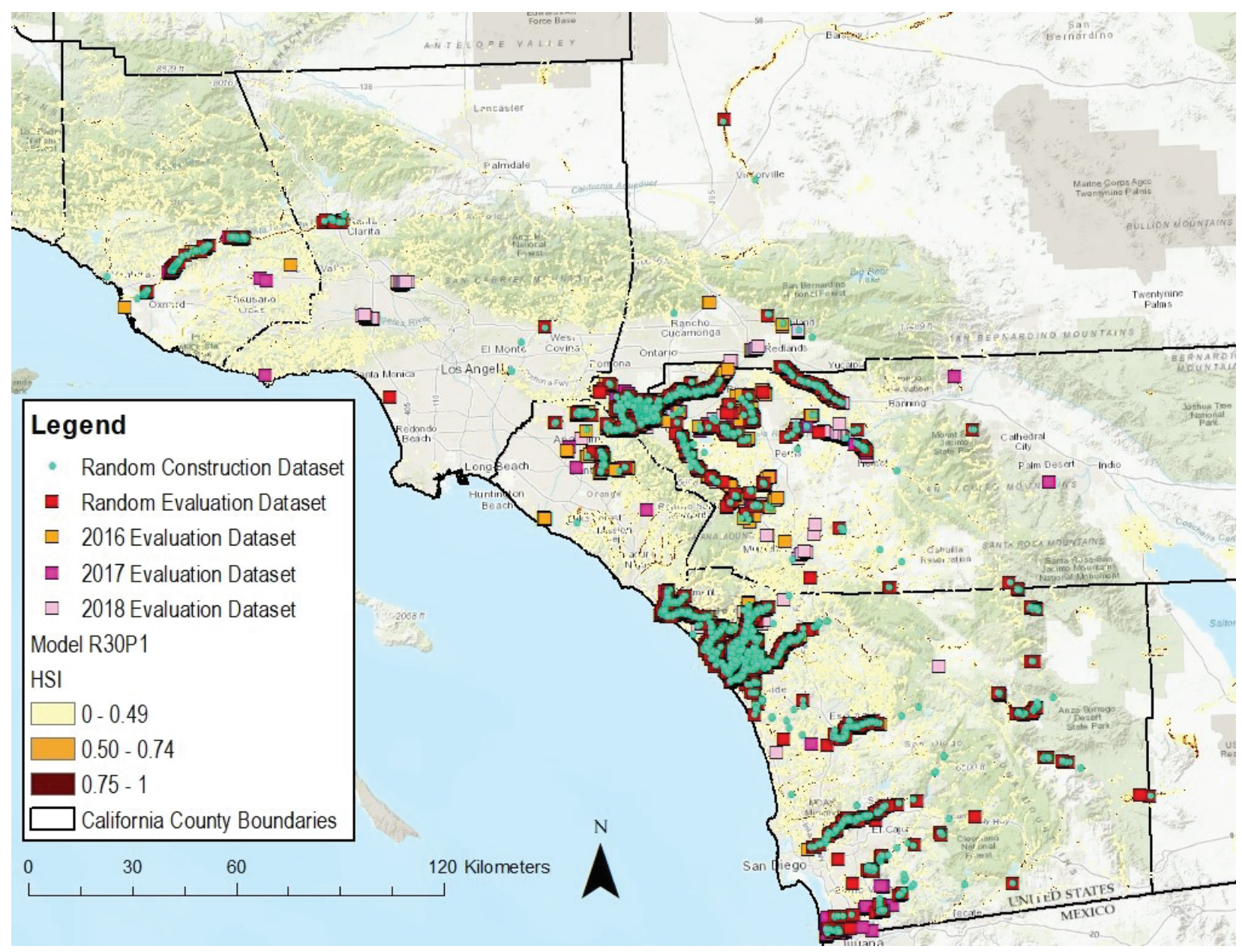

Figure 6. Model R30-P1 habitat suitability predictions and Least Bell's Vireo 1990-2018 locations used to construct and evaluate models for the current range in southern California. 


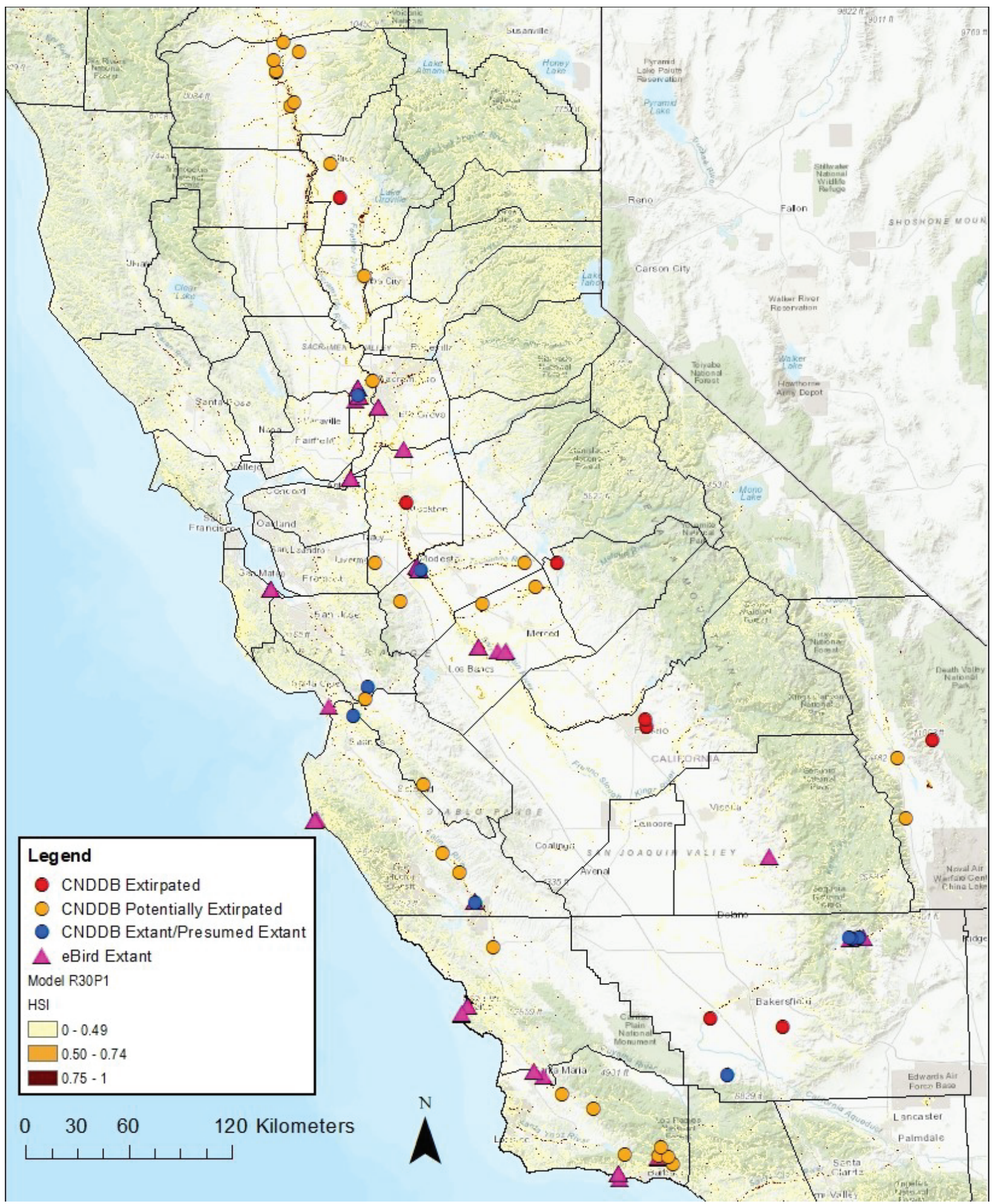

Figure 7. Model R30-P1 habitat suitability predictions for the historic range in California. Historic and recent California Natural Diversity Database (CNDDB) locations are classified as extirpated, potentially extirpated, and presumed extant based on current site conditions. eBird locations represent recent expansions into the historic range. 
Model R30-P1 differed from the second-best model predicting suitable habitat for the historic range, model R28-P1, by not including topographic heterogeneity or annual CWD. With the inclusion of these variables, model R28-P1 was more restrictive in habitat predictions than R30-P1 for the northern portion of the southern California study area and deserts (figs. 4, 8). Model R28-P1 was much more restrictive than model R30-P1 in predicting habitat outside the current range, especially in the northern portion of the historic range (figs. 5, 9).

We used aerial imagery to assess 63 observation areas in the historic range to identify current conditions at historic and recent Least Bell's Vireo locations and compare habitat suitability predictions (table 4). Across all observations in the historic range, 13 percent were developed, 51 percent supported only a small amount of riparian habitat, 3 percent were undeveloped but do not appear to support riparian habitat, and 33 percent had a relatively large amount of riparian habitat. Eight historic observations (13 percent) were defined as extirpated and nearly 50 percent were potentially extirpated with no vireos detected since 1990. Potentially extirpated observation areas displayed small amounts of remnant riparian habitat in 66 percent of cases, whereas 34 percent had substantial amounts of riparian vegetation. For 24 extant or potentially extant observations (observed in 1990 or after), there was an even split between areas with a small amount of riparian vegetation (46 percent) and with relatively large amounts (46 percent). Two extant observations at undeveloped sites did not appear to support any riparian vegetation. Riparian vegetation appeared to be adequately mapped at 67 percent of observation areas, appeared too restrictive at 14 percent, and too expansive at 19 percent. In evaluating habitat suitability from aerials, model R30-P1 performed well at 70 percent of occurrences, marginally at 25 percent, and poorly at 5 percent.

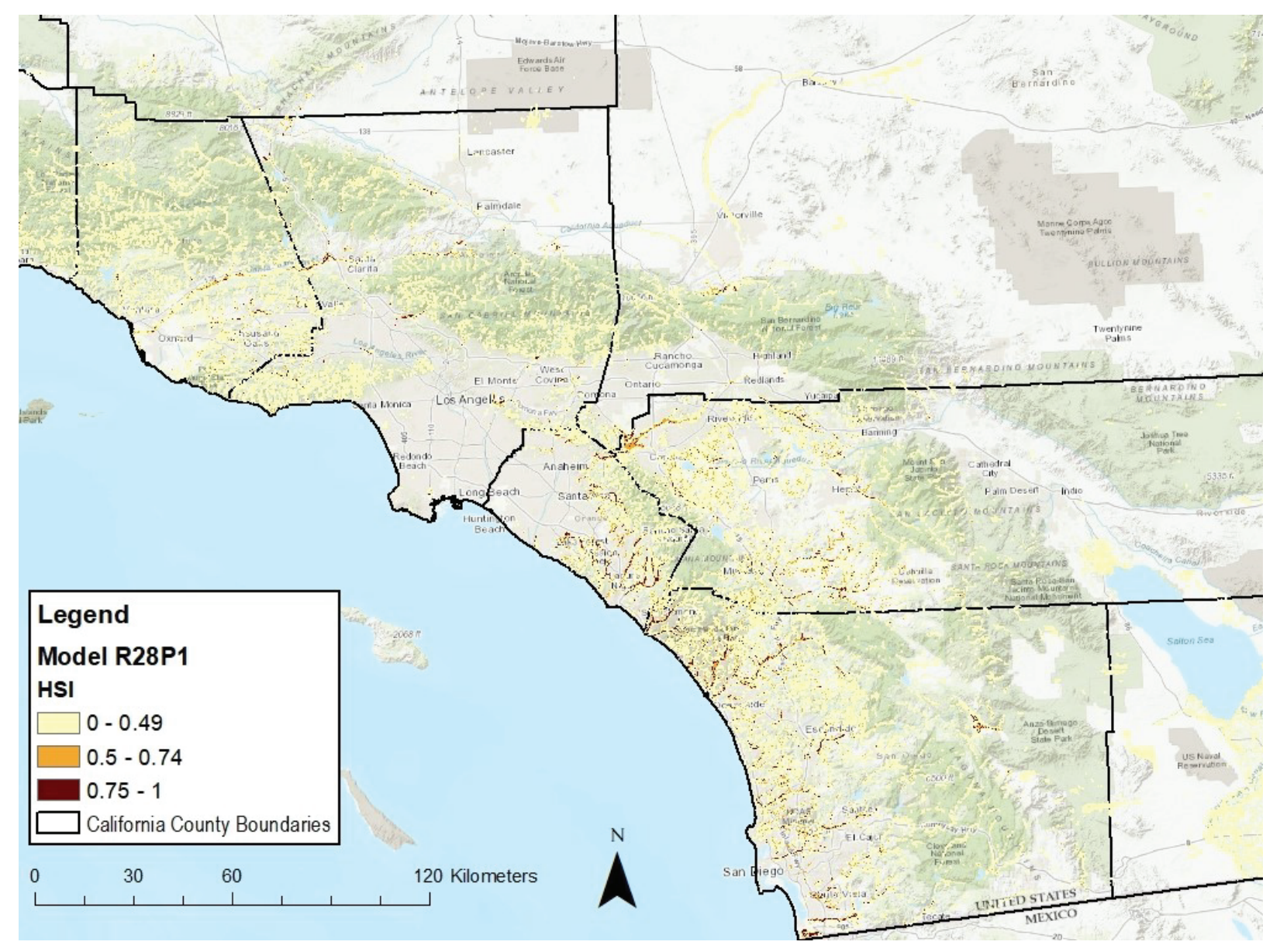

Figure 8. Model R28-P1 habitat suitability predictions for the current range in southern California. Suitable habitat is defined as habitat similarity index (HSI) greater than or equal to 0.5 . 


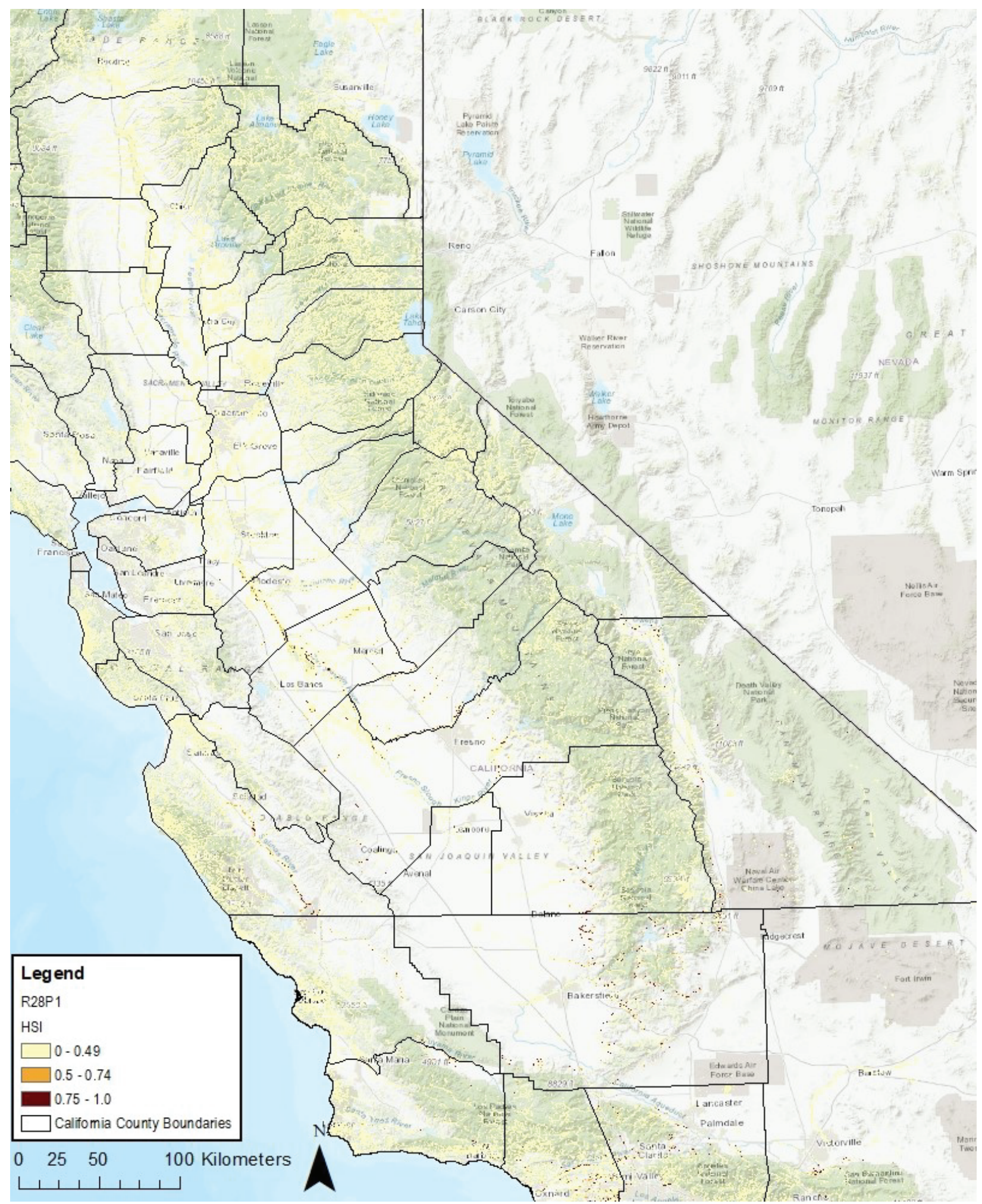

Figure 9. Model R28-P1 habitat suitability predictions for the historic range in California. Suitable habitat is defined as habitat similarity index (HSI) greater than or equal to 0.5 . 
We calculated and compared model R30-P1 variable means and std for grid points predicted as suitable and unsuitable across California for vireo model construction locations in the current range and for observation areas in the historic range (table 5). Vireos in the current range inhabited areas that average over 60 -percent riparian vegetation and flat land at the $150-\mathrm{m}$ scale, had shallow slopes, and were within $130 \mathrm{~m}$ of streams or rivers. There was little difference between mean values for model construction locations in the current range and predicted suitable habitat across California. In contrast, unsuitable habitat was characterized, on average, by steeper slopes with lower percentages of riparian vegetation and flat land at the 150-m scale. Mean values for slope and riparian vegetation lay outside the range of values for 95 percent of vireo model construction points. For vireo locations in the historic range, suitable habitat supported less riparian than most model construction dataset locations and unsuitable habitat was steeper with even less riparian vegetation.

Table 4. Assessment of historic and recent Least Bell's Vireo observations (California Natural Diversity Database, 2018; eBird, 2019) and R30-P1 model performance in California's historic range.

[Aerial photographs were used to assess conditions on the ground to determine the status of vireo observations and accuracy of riparian vegetation mapping at observation areas. Abbreviation: \%, percent]

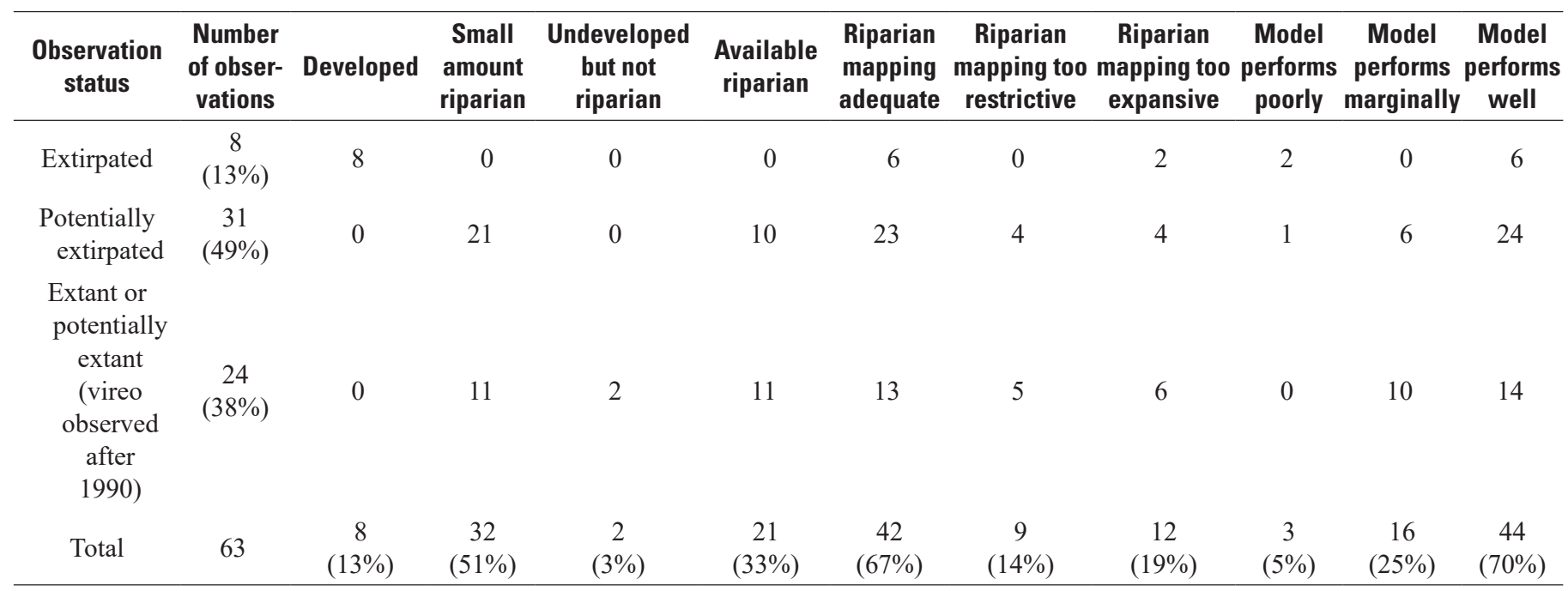

Table 5. Comparison of environmental variable means and standard deviation calculated for suitable and unsuitable habitat across California, for Least Bell's Vireo locations in the current range (model construction dataset) and for historic and recent vireo observation areas in the historic range.

[Environmental variable means falling outside 65 percent (mean plus or minus 1 standard deviation [std]) and 95 percent (mean plus or minus 2 std) of vireo observations in the current range are highlighted in light gray and dark gray, respectively. Abbreviations: n, number of samples; \%, percent; \pm , plus or minus; $\mathrm{m}, \mathrm{meter}]$

\begin{tabular}{|c|c|c|c|c|c|}
\hline Dataset & $\mathbf{n}$ & $\begin{array}{c}\text { Slope150m } \\
\text { Mean } \pm \text { std } \\
\text { (range) }\end{array}$ & $\begin{array}{l}\text { Riparian150p } \\
\text { Mean } \pm \text { std } \\
\text { (range) }\end{array}$ & $\begin{array}{c}\text { Flat150m } \\
\text { Mean } \pm \text { std } \\
\text { (range) }\end{array}$ & $\begin{array}{c}\text { Waterdistm } \\
\text { Mean } \pm \text { std } \\
\text { (range) }\end{array}$ \\
\hline $\begin{array}{l}\text { Vireo model construction dataset mean } \pm 1 \text { std }(65 \% \text { of vireo } \\
\text { locations) }\end{array}$ & 2,270 & $\begin{array}{l}3 \% \pm 4 \\
(0-7 \%)\end{array}$ & $\begin{array}{l}64 \% \pm 30 \\
(34-94 \%)\end{array}$ & $\begin{array}{l}62 \% \pm 29 \\
(33-91 \%)\end{array}$ & $\begin{array}{l}134 \mathrm{~m} \pm 230 \\
(0-364 \mathrm{~m})\end{array}$ \\
\hline $\begin{array}{l}\text { Vireo model construction dataset mean } \pm 2 \text { std ( } 95 \% \text { of vireo } \\
\text { locations) }\end{array}$ & 2,270 & $(0-11 \%)$ & $(4-100 \%)$ & $(4-100 \%)$ & $(0-594 \mathrm{~m})$ \\
\hline $\begin{array}{l}\text { Unsuitable habitat across California in the current and historic } \\
\text { ranges }\end{array}$ & $2,419,474$ & $13 \% \pm 11$ & $4 \% \pm 12$ & $25 \% \pm 39$ & $160 \mathrm{~m} \pm 208$ \\
\hline Suitable habitat at vireo observation areas in the historic range & 35 & $4 \% \pm 6$ & $25 \% \pm 18$ & $63 \% \pm 34$ & $169 \mathrm{~m} \pm 47$ \\
\hline Unsuitable habitat at vireo observation areas in the historic range & 10 & $7 \% \pm 6$ & $15 \% \pm 16$ & $41 \% \pm 34$ & $195 \mathrm{~m} \pm 90$ \\
\hline
\end{tabular}




\section{Amount of Suitable Habitat and Conservation in California}

We quantified suitable habitat acreages for counties and HUC 8 watersheds throughout the current and historic range in California and assessed recent (greater than or equal to 1990) and historic (less than 1990) Least Bell's Vireo observations (appendix 3, table 3.1). Across California, including areas outside the vireo's range, we modeled $5,703,847$ ha $(14,094,205$ acres) of riparian vegetation buffered $500 \mathrm{~m}$. Model R30-P1 predicted 5 percent or 259,785 ha (641,930 acres) as suitable vireo habitat across all of California. Of the suitable habitat, 32 percent $(84,206$ ha or 208,072 acres) was conserved. In the current southern California range, we modeled 846,241 ha (2,091,060 acres) of habitat and identified 6 percent as suitable, of which 41 percent was conserved (appendix 3, table 3.1). There were abundant recent and historic vireo locations in all counties in the current range. San Diego County contained the most suitable habitat with 16,284 ha ( 40,238 acres), followed by Riverside County.

We included 33 counties as part of the historic range in California (appendix 3, table 3.1) with 2,468,491 ha $(6,099,642$ acres) of modeled habitat. These 33 counties included 6 percent of predicted suitable habitat, of which 21 percent is conserved. Sixteen (48 percent) counties had historic vireo records and sixteen (48 percent) had recent records. Historic records extended from Tehama County south through the Sacramento and San Joaquin Valleys, along the central coast and peninsular ranges and east to Owens Valley and Death Valley (fig. 7). In the historic range, we had recent vireo records for the Sacramento Valley in Yolo County, in the San Joaquin Valley south to Tulare County, along the central coast from the Bay Area south to Santa Barbara, and at the Kern River in Kern County. There were two geographic clusters of vireo records with large amounts of suitable habitat (appendix 3, table 3.1; fig. 7). The northern San Joaquin Valley was one cluster, especially in Stanislaus, Merced, and San Joaquin Counties. A second cluster was along the central coast in Monterey, San Benito, San Luis Obispo, and Santa Barbara Counties.

The USFWS Least Bell's Vireo draft recovery plan (U.S. Fish and Wildlife Service, 1998) identifies 14 key population and metapopulation units across the vireo's current and historic range that are high priorities for protection and management. Key populations and metapopulations in areas we had identified as the historic range include the Santa Ynez River, Salinas River, San Joaquin Valley, and Sacramento Valley. Model R30-P1 identified 2,664 ha (6,583 acres) of suitable habitat in the Santa Ynez River with historic and recent vireo observations (appendix 3, table 3.1). Within Santa Barbara County, 20 percent of this suitable habitat was conserved. The Salinas River spans Monterey, San Benito, and San Luis Obispo Counties with a total of 11,622 ha (28,718 acres) of suitable habitat and historic and recent vireo observations. Almost 17 percent of this suitable habitat was conserved. The San Joaquin Valley includes all or parts of Kern, Kings, Tulare, Fresno, Madera, Merced, Stanislaus, and San Joaquin Counties. Suitable vireo habitat added up to 35,786 ha (88,426 acres), of which 25 percent ( 8,966 ha or 22,155 acres) was conserved. There were historic and recent vireo observations in this area. The Sacramento Valley metapopulation area included all or parts of Sacramento, Yolo, Sutter, Yuba, Colusa, Glenn, Butte, Tehama, and Shasta Counties. Suitable habitat in these counties totaled 54,108 ha (133,701 acres), of which 18 percent $(9,579$ ha or 23,670 acres) was conserved. The Sacramento Valley supported multiple historic observations along the length of the valley, whereas recent sightings were reported only from Yolo County at the southern end.

Imperial County is outside the historic range of Least Bell's Vireo and was not defined as part of the current range. However, starting in 1995, there were sporadic and increasing numbers of breeding season observations of Bell's vireo in the vicinity of the Salton Sea and New River (appendix 3, table 3.1).

\section{Discussion}

\section{Interpreting Model Results}

Simple models characterize Least Bell's Vireo habitat relationships in the current range and under novel conditions in the historic range. These simple models focus on local-scale riparian vegetation and topographic relationships. In the current range, model performance is not improved by adding climate, urbanization, or NDVI variables. Furthermore, the addition of these variables precludes predictions of suitable habitat in the historic range. Although vireo habitat is best described by relatively abundant riparian vegetation, shallow slopes, and flat land, these attributes vary. This variance in occupied conditions explains why the best model partitions are typically partition 1 , which characterizes these more variable habitat relationships. In the current and historic range, vireos are observed in "marginal" habitat with only small amounts of riparian vegetation or in steep sided drainages. It is unknown whether these observations are typical of breeding vireos or reflect migrating individuals, or individuals looking for territories and mates. Despite this variability in use of remnant or isolated riparian patches, most vireos occur in areas with abundant riparian habitat often associated with flat floodplains and shallow sloped drainages. 
Despite being a simple model, the best performing Least Bell's Vireo model is discriminatory. Only 6 percent of the riparian modeling grid (buffered $500 \mathrm{~m}$ with other land cover types) is considered suitable for southern California and for the entire state. This represents an even smaller fraction for all available riparian habitats because not all riparian vegetation types were included in the modeling grid. This ability to distinguish areas likely to support vireos allows land managers to prioritize areas for surveys, substantially reduce costs, and increase the ability to detect vireos if they are present in an area.

There are likely inaccuracies in the riparian vegetation mapping that may lead to poor habitat predictions on the ground. Merging multiple vegetation maps, many of which are outdated and of differing scales with multiple vegetation classification schemes, is problematic. Riparian systems are dynamic and vegetation composition and structure can change dramatically over time with disturbances from flooding, fire, and invasive nonnative plants. In response to hydrological changes and coupled with natural succession processes, vegetation mapping of a particular area can quickly become outdated. Unfortunately, NDVI, which reflects changes in growing vegetation over seasonal and annual temporal scales, performed poorly in predicting riparian habitat associated with vireo occurrences. Other vegetation communities, such as chaparral and oak woodland, were not well distinguished from riparian using NDVI. Normalized difference vegetation index values changed among years in the same area depending on rainfall conditions. Annual (and seasonal) changes in NDVI values result in lack of consistency related to vireo habitat use. New technologies, such as unmanned aircraft systems and improved remote imagery classification, are improving vegetation mapping efficiencies and could lead to a better riparian vegetation map in the future. Improving riparian vegetation mapping across the state using a consistent mapping methodology and classification scheme likely would improve habitat suitability predictions.

At present, it will be difficult to evaluate model performance in the historic range because there are currently so few Least Bell's Vireos outside of southern California. The lack of birds at a site in the historic range does not mean the habitat is unsuitable; rather that the area has not been recolonized or population numbers are low, and habitat is not fully occupied. Over time, if vireo populations continue to expand in southern California, we expect to see more birds venturing into the historic range. If this process occurs and populations become established, we can then more fully evaluate habitat model predictions in occupied areas of the historic range.

\section{Application of Model to Conservation and Management}

This GIS-based habitat suitability model can be used to identify and prioritize areas to survey for vireos to determine their current distribution. By distinguishing the 6 percent of riparian habitat throughout the state most likely to be used by vireos, this model allows for more efficient, cost effective, and focused survey efforts. There currently is interest in surveying historical habitat to detect recolonization, particularly along major riparian drainages along the central coast. The habitat suitability map assesses the status of vireo habitat throughout the large historic range by reflecting changes in habitat condition during the last 30 years, both positive and negative, that influence where vireos are likely to occur today. The model quantifies, by county and watershed, those areas with the most suitable habitat. This model also can be used to identify areas to consider for focused surveys in key population and metapopulation areas identified in the draft recovery plan (U.S. Fish and Wildlife Service, 1998). Surveying these areas could provide information that is important for evaluating federal endangered status and recovery.

For the current range, this habitat model provides a sampling frame to design occupancy studies or other assessments of abundance and population trends. If vireo populations expand and become established in the historic range, this model also could be used as the sampling frame for long-term monitoring studies in recolonized habitat.

The map provides insight into management of this species by identifying areas to consider for restoration and enhancement or brown-headed cowbird management to improve the quality of potential vireo habitat. Restoration could be prioritized for lower habitat suitability sites next to large blocks of high and very high suitability habitat. Creating larger blocks of habitat could potentially support larger breeding populations in the future. The habitat suitability map can be compared with maps of shot hole borer infestations to identify areas where potential vireo habitat may be vulnerable to Fusarium dieback. This information can be used to guide development of management strategies and funding priorities. The habitat model also identifies areas that could be important for future conservation, assuming Least Bell's Vireo populations continue to expand in the historic range over time. A conservation strategy could be developed in combination with a restoration strategy to more efficiently guide recovery efforts. 
The Least Bell's Vireo habitat suitability model could be an important tool to guide the next phase of recovery. As managers and partners embark on "discovery" surveys to determine the status of the vireo in its historic range, the model can help them devote resources in an effective and efficient manner. We provide the following suggestions to aid planning and implementing discovery surveys:

- Prioritize surveys in rivers or watersheds that support large areas of high and very high suitability habitat that can support breeding populations of vireos. Where feasible, survey suitable habitat areas that have recent or historic vireo observations. Examples of such sites are the San Joaquin Valley and central coast regions.

- Prioritize areas that are close to source populations in southern California. If vireos are consistently found in these areas or establish breeding populations, expand surveys to more northerly areas with concentrations of suitable habitat.

- Collect covariate data during field surveys characterizing habitat suitability that can be used to evaluate model predictions. This would include categorizing the amount of different vegetation communities, identifying dominant plant species including nonnative invasive plants, recording information on vireo occurrence and breeding status, and habitat suitability evaluations by biologists experienced with Least Bell's Vireos. Habitat data would be most valuable if collected across environmental conditions, including suitable and unsuitable habitats.

- As data from discovery surveys and new vegetation mapping become available, it will be possible to periodically review and update the Least Bell's Vireo habitat model to maximize its usefulness. Vireo expansion and reestablishment in the historic range would provide the necessary data to further improve the model by incorporating those locations into the southern California constructed model.

\section{References Cited}

Barrows, C.W., and Murphy-Mariscal, M.L., 2012, Modeling impacts of climate change on Joshua trees at their southern boundary-How scale impacts prediction: Biological Conservation, v. 152, p. 29-36, https://doi.org/10.1016/j.biocon.2012.03.028.

Boland, J.M., 2016, The impact of an invasive ambrosia beetle on the riparian habitats of the Tijuana River Valley, California: PeerJ, v. 4, 16 p., https://doi.org/10.7717\%2Fpeerj.2141.

Boland, J.M., 2017, The ecology and management of the Kuroshio Shot Hole Borer in the Tijuana River Valley: Final Report prepared for the U.S. Navy, U.S. Fish and Wildlife Service, and Southwest Wetlands Interpretive Association, Cooperative Agreement Award F16AC01065, 43 p.

California Department of Fish and Wildlife, 2018, Conservation plans by species: California Department of Fish and Wildlife web page, https://www.wildlife.ca.gov/conservation/planning/nccp.

California Department of Forestry and Fire Protection, 2015, CALFIRE-Fire and Resource Assessment Program (FRAP) Vegetation (fveg) [ds1327]: California Department of Forestry and Fire Protection, Publication Date: 2015-01-0100:00:00.

California Natural Diversity Database, 2018, California Natural Diversity Database (CNDDB): California Department of Fish and Wildlife, https://www.wildlife.ca.gov/Data/CNDDB.

California Protected Areas Database, 2019, California protected areas database: California's Protected Areas, accessed November 2019, at www.calands.org.

Chefaoui, R.M., and Lobo, J.M., 2008, Assessing the effects of pseudo-absences on predictive distribution model performance: Ecological Modelling, v. 210, no. 4, p. 478-486, https://doi.org/10.1016/j.ecolmodel.2007.08.010.

Dilts, T.E., Weisberg, P.J., Dencker, C.M., and Chambers, J.C., 2015, Functionally relevant climate variables for arid lands - A climatic water deficit approach for modelling desert shrub distributions: Journal of Biogeography, v. 42, no. 10, p. 1986-1997, https://doi.org/10.1111/jbi.12561. 
eBird, 2019, eBird - An online database of bird distribution and abundance [web application]: Ithaca, New York, Cornell Lab of Ornithology, eBird, accessed September 3, 2019, at http:/www.ebird.org.

Elith, J., Graham, C.H., Anderson, R.P., Dudík, M., Ferrier, S., Guisan, A., Hijmans, R.J., Huettmann, F., Leathwick, J.R., Lehmann, A., Li, J., Lohmann, L.G., Loiselle, B.A., Manion, G., Moritz, C., Nakamura, M., Nakazawa, Y., Overton, J.M., Peterson, A.T., Phillips, S.J., Richardson, K., Scachetti-Pereira, R., Schapire, R.E., Soberón, J., Williams, S., Wisz, M.S., and Zimmerman, N.E., 2006, Novel methods improve predictions of species' distributions from occurrence data: Ecography, v. 29, no. 2, p. 129-151, https://doi.org/10.1111/j.2006.0906-7590.04596.x.

Eskalen, A., Gilbert, G., Lynch, S., Mitrovich, M., Naegelem, J., Burger, J., Principe, Z., Miller, W., Williams, C., and Beck, C., 2019, Management and monitoring of Fusarium dieback - shothole borer complex: California Department of Fish and Wildlife Local Assistance Grant Final Report LAG No, p. 1682904.

Fielding, A.H., and Bell, J.F., 1997, A review of methods for the assessment of prediction errors in conservation presence/ absence models: Environmental Conservation, v. 24, no. 1, p. 38-49, https://doi.org/10.1017/S0376892997000088.

Goguen, C.B., and Mathews, N.E., 1999, Review of the causes and implications of the association between cowbirds and livestock, in Horrison, M.L., Hall, L.S., Robinson, S.K., Rothstein, S.I., Hahn, D.C., and Rich, T.D., eds., Research and management of the brown-headed cowbird in western landscapes: Studies in Avian Biology, v. 18, p. 10-17.

Goldwasser, S., Gaines, D., and Wilbur, S.R., 1980, The Least Bell's Vireo in California-A de factor endangered race: American Birds, v. 34, no. 5, p. 742-745.

Guisan, A., and Zimmerman, N.E., 2000, Predictive habitat distribution models in ecology: Ecological Modelling, v. 135, no. 2-3, p. 147-186, https://doi.org/10.1016/S0304-3800(00)00354-9.

Howell, C.A., Wood, J.K., Dettling, M.D., Griggs, K., Otte, C.C., Lina, L., and Gardali, T., 2010, Least Bell's Vireo breeding records in the Central Valley following decades of extirpation: Western North American Naturalist, v. 70, no. 1, p. 105-113, https://doi.org/10.3398/064.070.0111.

Howell, S.L., and Kus, B.E., 2018, Least Bell's Vireo response to kuroshio shot hole borer/fusarium dieback at the Tijuana River, California: U.S. Geological Survey 2017 Data Summary, 32 p.

Klausmeyer, K., and Howard, J., 2016, Indicators of California's groundwater dependent ecosystems, Draft version 0.4: San Francisco, Calif., The Nature Conservancy.
Knick, S.T., and Rotenberry, J.T., 1998, Limitations to mapping habitat use areas in changing landscapes using the Mahalanobis Distance statistic: Journal of Agricultural Biological \& Environmental Statistics, v. 3, no. 3, p. 311-322, https://doi.org/10.2307/1400585.

Knick, S.T., Hanser, S.E., and Preston, K.L., 2013, Modeling ecological minimum requirements for distribution of greater sage-grouse leks-Implications for population connectivity across their western range, U.S.A: Ecology and Evolution, v. 3, no. 6, p. 1539-1551, https://doi.org/10.1002/ece3.557.

Kus, B.E., 1998, Use of restored riparian habitat by the endangered Least Bell's Vireo (Vireo bellii pusillus): Restoration Ecology, v. 6, no. 1, p. 75-82, https://doi.org/10.1046/j.1526-100x.1998.06110.x.

Kus, B.E., 2002, Fitness consequences of nest desertion in an endangered host, the Least Bell's Vireo: The Condor, v. 104, no. 4, p. 795-802, https://doi.org/10.1093/condor/104.4.795.

Kus, B.E., and Whitfield, M.J., 2005, Parasitism, productivity, and population growth-Response of Least Bell's Vireos (Vireo bellii pusillus) and southwestern willow flycatchers (Empidonax traillii extimus) to cowbird (Molothrus spp.) control: Ornithological Monographs, v. 2005, no. 57, p. 16-27, https://doi.org/10.2307/40166811.

Kus, B.E., Howell, S., Pottinger, R., and Treadwell, M., 2017, Recent population trends in Least Bell's Vireos and southwestern willow flycatchers - 2016 update: Carlsbad, Calif., Presentation to the Biennial Meeting of the Riparian Birds Working Group, March 16, 2017.

Kus, B., Hopp, S.L., Johnson, R.R., and Brown, B.T., 2020, Bell's vireo (Vireo bellii), version 1.0, in Poole, A.F., ed., Birds of the world: Ithaca, N.Y., USA, Cornell Lab of Ornithology, https://doi.org/10.2173/bow.belvir.01.

Laymon, S.A., 1987, Brown-headed cowbirds in CaliforniaHistorical perspectives and management opportunities in riparian habitats: Western Birds, v. 18, p. 63-70.

Preston, K.L., Rotenberry, J.T., Redak, R.A., and Allen, M.F., 2008, Habitat shifts of endangered species under altered climate conditions-Importance of biotic interactions: Global Change Biology, v. 14, no. 11, p. 2501-2515, https://doi.org/10.1111/j.1365-2486.2008.01671.x.

Preston, K.L., Kus, B.E., and Perkins, E.E., 2019, Least Bell's Vireo habitat suitability model for California (2019): U.S. Geological Survey data release, https://doi.org/10.5066/P90T9WT2. 
Rotenberry, J.T., Knick, S.T., and Dunn, J.E., 2002, A minimalist approach to mapping species' habitatPearson's planes of closest fit, in Scott, J.M., Heglund, P.J., Morrison, M.L., Haufler, J.B., Raphael, M.G., Wall, W.A., and Samson, F.B., eds., Predicting species occurrencesIssues of accuracy and scale: Washington, D.C., U.S.A, Island Press, p. 281-289.

Rotenberry, J.T., Preston, K.L., and Knick, S.T., 2006, GIS-based niche modeling for mapping species' habitat: Ecology, v. 87, no. 6, p. 1458-1464, https://doi.org/10.1890/ 0012-9658(2006)87[1458:GNMFMS]2.0.CO;2.

Sappington, J.M., Longshore, K.M., and Thompson, D.B., 2007, Quantifying landscape ruggedness for animal habitat analysis - A case study using bighorn sheep in the Mohave Desert: The Journal of Wildlife Management, v. 71, no. 5, p. 1419-1426, https://doi.org/10.2193/2005-723.

Smith, F., 1977, A short review of the status of riparian forests in California, in Sands, A., ed., Riparian forests in California-Their ecology and conservation: University of California, Davis, Institue of Ecology Pub. 15, p. 1-2.
University of California Agriculture and Natural Resources, 2018a, Invasive shot hole borers-ISHB-FD distribution in California: University of California Agriculture and Natural Resources, https://ucanr.edu/sites/pshb/Map/.

University of California Agriculture and Natural Resources, 2018b, Invasive shot hole borers - Distribution of PSHB/ FD and KSHB/FD in California: University of California Agriculture and Natural Resources, https:/ucanr.edu/sites/ pshb/pest-overview/ishb-fd-distribution-in-california/.

U.S. Fish and Wildlife Service, 1986, 50 CFR Part 17Endangered and threatened wildlife and plantsDetermination of endangered status for the Least Bell's Vireo: Federal Register, v. 51, no. 85, p. 16474-16481.

U.S. Fish and Wildlife Service, 1998, Draft recovery plan for the Least Bell's Vireo (Vireo bellii pusillus): Portland, Oreg., U.S. Fish and Wildlife Service, 139 p.

U.S. Fish and Wildlife Service, 2006, Least Bell's Vireo (Vireo bellii pusillus) 5-year review-Summary and evaluation: Carlsbad, Calif., U.S. Fish and Wildlife Service, Carlsbad Fish and Wildlife Office, 26 p. 


\section{Appendix 1. Vegetation Maps for Various Geographic Areas of California and Selected Riparian Vegetation Community Categories Used to Model Least Bell's Vireo Habitat}

Table 1.1. Vegetation maps and selected riparian vegetation community categories for geographic areas of California merged together to create the riparian vegetation layer used in modeling Least Bell's Vireo habitat.

\begin{tabular}{ccc}
\hline Vegetation map name & Geographic area & Riparian vegetation category \\
\hline $\begin{array}{c}\text { Fire Resource Assessment } \\
\text { Program } 2015\end{array}$ & California & Desert riparian, Valley-foothill riparian \\
\hline & & Anemopsis californica alliance, Arundo donax semi-natural stands, Baccharis \\
AECOM 2014 & salicifolia alliance, Naturalized warm-temperate riparian and wetland \\
& Semi-natural stands, Platanus racemosa alliance, Pluchea sericea alliance, \\
& Populus fremontii alliance, Quercus agrifolia alliance, Salix exigua alliance, \\
& Salix gooddingii alliance, Salix laevigata alliance, Salix lasiolepis alliance, \\
& Tamarix spp. semi-natural stands, wash/channel, Washingtonia sp./ Phoenix sp.
\end{tabular}

Arroyo willow alliance, Black willow alliance, Black willow/mule fat association, Black willow-shining willow mapping unit, Black willow-shining willow-Fremont cottonwood association, Blue elderberry/mule fat mapping unit, California sycamore alliance, California sycamore-Fremont cottonwood alliance, California sycamore-Fremont cottonwood/arroyo willow association, California sycamore-red willow/arroyo Willow-mule fat association, Desert olive alliance,

Desert olive-willow association, Emory's baccharis mapping unit, Fremont Riverside 2015 Western Riverside County cottonwood alliance, Fremont cottonwood/mule fat association, Fremont cottonwood-black willow/mule fat association, Fremont cottonwood-red willow association, Fremont cottonwood-red willow/arroyo willow/mule fat association, Fremont cottonwood-sycamore-willow mapping unit, Fremont cottonwood-willow mapping unit, Mule fat alliance, Mule fat-Mexican elderberry association, Red willow alliance, Red willow/arroyo willlow/mugwort association, Shining willow napping unit, Tamarisk alliance, White Alder alliance, Willow mapping unit

\begin{tabular}{|c|c|c|}
\hline NAS Miramar 2012-14 & $\begin{array}{l}\text { Naval Air Station } \\
\text { Miramar }\end{array}$ & $\begin{array}{l}\text { Arroyo willow thickets, Black willow thickets, Mule fat thickets, Tamarisk stand, } \\
\text { Western sycamore woodland }\end{array}$ \\
\hline $\begin{array}{l}\text { Central Coastal Orange } \\
\text { County } 2013\end{array}$ & Orange County & $\begin{array}{c}\text { Alnus rhombifolia alliance, Arundo donax alliance, Baccharis salicifolia alliance, } \\
\text { Platanus racemosa alliance, Populus fremontii alliance, Salix gooddingii } \\
\text { alliance, Salix laevigata alliance, Salix lasiolepis alliance, Sambucus nigra } \\
\text { alliance, Southwest North American riparian Evergreen and deciduous } \\
\text { woodland, Southwest North American riparian/wash scrub }\end{array}$ \\
\hline
\end{tabular}

Giant reed riparian scrub, Mexican elderberry woodland, mule fat scrub, Mule fat

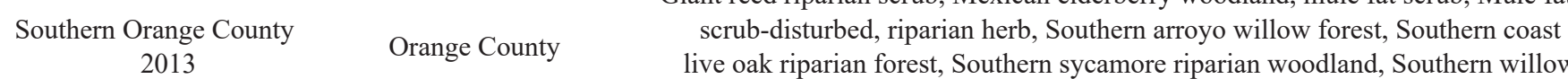
live oak riparian forest, Southern sycamore riparian woodland, Southern willow scrub, Southern willow scrub-disturbed

\begin{tabular}{|c|c|c|}
\hline NAVFAC Fallbrook & $\begin{array}{c}\text { San Diego County - } \\
\text { Naval Weapons Station } \\
\text { Fallbrook }\end{array}$ & Arroyo willow alliance, California sycamore alliance, Mule fat alliance \\
\hline
\end{tabular}


Table 1.1. Vegetation maps and selected riparian vegetation community categories for geographic areas of California merged together to create the riparian vegetation layer used in modeling Least Bell's Vireo habitat.—Continued

\begin{tabular}{lll}
\hline Vegetation map name & Geographic area & Riparian vegetation category \\
\hline
\end{tabular}

Fremont cottonwood forest alliance, Fremont cottonwood-red willow woodland, Fremont cottonwood, Honey mesquite woodland association, Honey mesquite/ saltbush-bush seepweed woodland alliance, Juglans hindsii, Juglans hindsii and hybrids, Juglans hindsii, Juglans regia and Hybrids semi-natural stands, Mixed riparian forest, Mixed riparian forest (Disturbed), Mixed riparian scrub, Mixed riparian scrub-Arundo donax, Mixed willow scrub, Mixed willow forest, Mixed Willow-Arundo donax, Narrowleaf willow temporarily flooded shrubland, Naturalized warm-temperate riparian and wetland, Palustrine, emergent, persistent scrub-shrub seasonally flooded, Palustrine, emergent, persistent scrub-shrub seasonally flooded - fresh tidal, Palustrine, emergent, persistent scrub-shrub seasonally saturated, Palustrine, emergent, persistent scrub-shrub temporarily flooded, Palustrine, emergent, persistent scrub-shrub temporarily flooded - fresh tidal, Palustrine, emergent, persistent, seasonally flooded, partly drained/ ditched, Palustrine, emergent, persistent, seasonally flooded/saturated, Palustrine, forested, emergent, persistent, seasonally flooded, Palustrine, forested, emergent, persistent, seasonally flooded - fresh tidal, Palustrine, forested, emergent, persistent, seasonally saturated, Palustrine, forested, emergent, persistent, temporarily flooded, Palustrine, scrub-shrub, emergent, persistent, seasonally flooded, Palustrine, scrub-shrub, emergent, persistent, seasonally flooded - fresh tidal, Palustrine, scrub-shrub, emergent, persistent, seasonally saturated, Palustrine, scrub-shrub, emergent, Persistent, semi-permanently flooded, Palustrine, scrub-shrub, emergent, persistent, temporarily flooded, Palustrine, scrub-shrub, emergent, Persistent, temporarily flooded - fresh tidal, Palustrine, scrub-shrub, emergent, Persistent, temporarily flooded, partly drained/ditched, Palustrine, scrub-shrub, forested, seasonally flooded, Palustrine, scrub-shrub, forested, seasonally flooded - fresh tidal,

Klausmeyer and Howard (2016)-Continued
California-Continued
Palustrine, scrub-shrub, forested, seasonally saturated, Palustrine, scrub-shrub, forested, semi-permanently flooded, Palustrine, scrub-shrub, forested, temporarily flooded, Palustrine, scrub-shrub, seasonally flooded, Palustrine, scrub-shrub, seasonally flooded - fresh tidal, Palustrine, scrub-shrub, seasonally flooded, beaver, Palustrine, scrub-shrub, seasonally flooded, partly drained/ ditched, Palustrine, scrub-shrub, seasonally flooded/saturated, Palustrine, scrub-shrub, seasonally saturated, Palustrine, scrub-shrub, semi-permanently flooded, Palustrine, scrub-shrub, semi-permanently flooded - fresh tidal, Palustrine, scrub-shrub, semi-permanently flooded, beaver, Palustrine, scrub-shrub, temporarily flooded, Palustrine, scrub-shrub, temporarily flooded fresh tidal, Palustrine, scrub-shrub, temporarily flooded, partly drained/ditched, Palustrine, scrub-shrub, unconsolidated bottom, semi-permanently flooded, Palustrine, scrub-shrub, unconsolidated shore, intermittently flooded, Palustrine, scrub-shrub, unconsolidated shore, seasonally flooded, Palustrine, scrub-shrub, unconsolidated shore, seasonally flooded - fresh tidal, Palustrine, scrub-shrub, unconsolidated shore, temporarily flooded, Palustrine, unconsolidated shore, scrub-shrub, broad-leaved-evergreen, intermittently flooded, Palustrine, unconsolidated shore, scrub-shrub, broad-leaved- evergreen, temporarily flooded, Palustrine, unconsolidated shore, scrub-shrub, needle-leaved deciduous, intermittently flooded, Palustrine, unconsolidated shore, scrub-shrub, seasonally flooded, Palustrine, unconsolidated shore, scrub-shrub, temporarily flooded,

Platanus racemosa, Platanus racemosa - Populus fremontii, Platanus racemosa - Populus fremontii/Salix lasiolepis, Platanus racemosa - Quercus agrifolia,

Platanus racemosa - Salix laevigata, Platanus racemosa - Salix laevigata/Salix lasiolepis - Baccharis salicifolia, Platanus racemosa (Disturbed), Platanus racemosa (Mixed), Platanus racemosa / Baccharis salicifolia, Platanus racemosa woodland/forest alliance, Platanus racemosa-Populus fremontii / Salix lasiolepis, Platanus racemosa-Quercus agrifolia 
Table 1.1. Vegetation maps and selected riparian vegetation community categories for geographic areas of California merged together to create the riparian vegetation layer used in modeling Least Bell's Vireo habitat.-Continued

\begin{tabular}{|c|c|c|}
\hline Vegetation map name & Geographic area & Riparian vegetation category \\
\hline $\begin{array}{l}\text { Klausmeyer and Howard } \\
\text { (2016)_Continued }\end{array}$ & California-Continued & 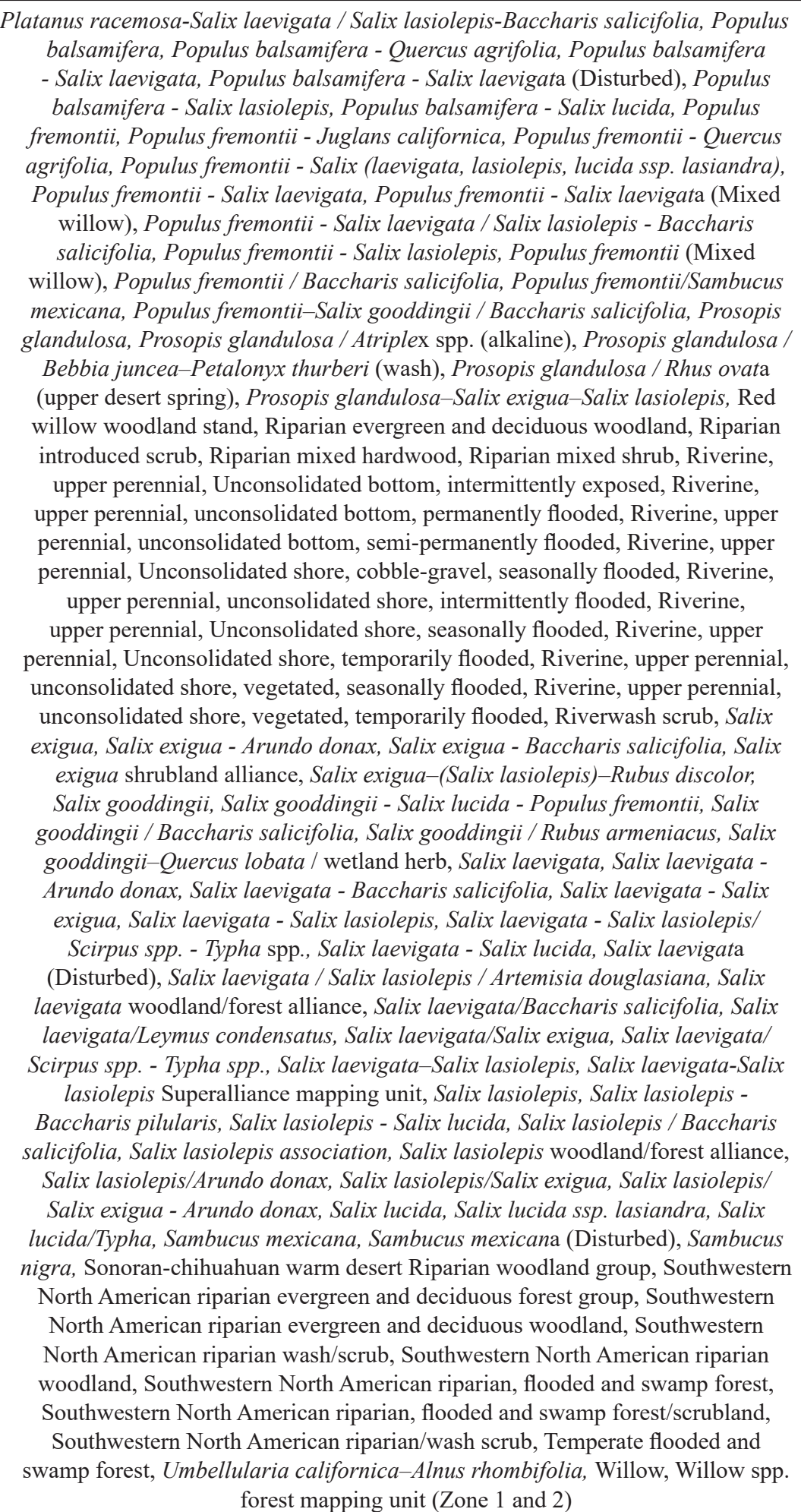 \\
\hline
\end{tabular}




\section{Appendix 2. Twenty Top Performing Least Bell's Vireo Habitat Suitability Models}

Table 2.1. Twenty top performing Least Bell's Vireo habitat suitability models based on the area under the curve (AUC) metric and median habitat similarity index () values for randomly selected model construction and evaluation datasets, the 2016 (average rainfall), 2017 (above average rainfall), and 2018 (below average rainfall) evaluation datasets, and the randomly selected pseudo-absence dataset.

[The selected model is highlighted in gray and performs well predicting suitable habitat in the current southern California range and is the top model predicting habitat in the historic range in California. Abbreviations: AUC, area under the curve; HSI, habitat similarity index; CWD, cumulative water deficit]

\begin{tabular}{|c|c|c|c|c|c|c|c|c|c|c|}
\hline $\begin{array}{l}\text { Model } \\
\text { number- } \\
\text { partition }\end{array}$ & Model type & Model variables & $\begin{array}{l}\text { Number } \\
\text { of } \\
\text { variables }\end{array}$ & AUC & $\begin{array}{l}\text { Median } \\
\text { random } \\
\text { calibration } \\
\text { HSI }\end{array}$ & $\begin{array}{c}\text { Random } \\
\text { dataset } \\
\text { HSI }\end{array}$ & $\begin{array}{c}2016 \\
\text { validation } \\
\text { HSI }\end{array}$ & $\begin{array}{c}2017 \\
\text { validation } \\
\text { HSI }\end{array}$ & $\begin{array}{c}2018 \\
\text { validation } \\
\text { HSI }\end{array}$ & $\begin{array}{l}\text { Pseudo- } \\
\text { absence } \\
\text { validation } \\
\text { HSI }\end{array}$ \\
\hline R30-P1 & $\begin{array}{l}\text { Topography, local-scale riparian and } \\
\text { distance to water }\end{array}$ & $\begin{array}{l}\text { slope } 150 \mathrm{~m} \text {, flat } 150 \mathrm{~m} \text {, riparian } 150 \mathrm{p} \text {, } \\
\text { waterdistm }\end{array}$ & 4 & 0.925 & 0.70 & 0.70 & 0.66 & 0.64 & 0.63 & 0 \\
\hline R1-P1 & $\begin{array}{l}\text { Winter climate, topography, } \\
\text { local-scale riparian, urbanization } \\
\text { and NDVI, distance to water and } \\
\text { annual CWD }\end{array}$ & $\begin{array}{l}\text { prec_OD_av, minT_OD_av, maxT_ } \\
\text { OD_av, dem } 150 \mathrm{~m} \text {, slope } 150 \mathrm{~m}, \\
\text { topo } 150 \mathrm{~m} \text {, flat } 150 \mathrm{~m} \text {, riparian } 150 \mathrm{p}, \\
\text { urban } 150 \mathrm{p}, \text { NDVImean } 150, \\
\text { waterdistm, cwd_anntot }\end{array}$ & 12 & 0.932 & 0.71 & 0.69 & 0.72 & 0.66 & 0.70 & 0 \\
\hline R29-P1 & $\begin{array}{l}\text { Topography, local-scale riparian and } \\
\text { annual CWD }\end{array}$ & $\begin{array}{l}\text { slope } 150 \mathrm{~m} \text {, flat } 150 \mathrm{~m} \text {, riparian } 150 \mathrm{p} \text {, } \\
\text { cwd anntot }\end{array}$ & 5 & 0.931 & 0.76 & 0.77 & 0.66 & 0.65 & 0.58 & 0 \\
\hline R5-P1 & $\begin{array}{l}\text { Pre-breeding climate, topography, } \\
\text { local-scale riparian, urbanization } \\
\text { and NDVI, distance to water and } \\
\text { annual CWD }\end{array}$ & $\begin{array}{l}\text { prec_JM_av, minT_JM_av, maxT_ } \\
\text { JM_av, dem150m, slope } 150 \mathrm{~m}, \\
\text { topo150m, flat150m, riparian } 150 \mathrm{p}, \\
\text { urban150p, NDVImax } 150, \\
\text { waterdistm, cwd_anntot }\end{array}$ & 12 & 0.930 & 0.74 & 0.73 & 0.72 & 0.69 & 0.69 & 0 \\
\hline R23-P1 & $\begin{array}{l}\text { Pre-breeding precipitation and } \\
\text { minimum temperature, topography, } \\
\text { local-scale riparian, urbanization } \\
\text { and NDVI, distance to water and } \\
\text { annual CWD }\end{array}$ & $\begin{array}{l}\text { prec_JM_av, minT_JM_av, dem } 150 \mathrm{~m} \text {, } \\
\text { slope } 150 \mathrm{~m} \text {, topo } 150 \mathrm{~m} \text {, flat } 150 \mathrm{~m}, \\
\text { riparian } 150 \mathrm{p} \text {, urban } 150 \mathrm{p}, \\
\text { NDVImax } 150 \text {, waterdistm, cwd_- } \\
\text { anntot }\end{array}$ & 11 & 0.930 & 0.75 & 0.72 & 0.68 & 0.64 & 0.67 & 0 \\
\hline R2-P1 & $\begin{array}{l}\text { Pre-breeding climate, topography, } \\
\text { local-scale riparian, urbanization } \\
\text { and NDVI, distance to water and } \\
\text { annual CWD }\end{array}$ & $\begin{array}{l}\text { prec_JM_av, minT_JM_av, maxT_ } \\
\text { JM_av, dem } 150 \mathrm{~m} \text {, slope } 150 \mathrm{~m}, \\
\text { topo } 150 \mathrm{~m} \text {, flat } 150 \mathrm{~m} \text {, riparian } 150 \mathrm{p}, \\
\text { urban } 150 \mathrm{p}, \text { NDVImean } 150, \\
\text { waterdistm, cwd_anntot }\end{array}$ & 12 & 0.930 & 0.72 & 0.69 & 0.72 & 0.67 & 0.71 & 0 \\
\hline R18-P1 & $\begin{array}{l}\text { Breeding climate, topography, } \\
\text { local-scale riparian and } \\
\text { urbanization }\end{array}$ & $\begin{array}{l}\text { prec_AJ_av, minT_AJ_av, maxT__ } \\
\text { AJ_av, dem } 150 \mathrm{~m}, \text { slope } 150 \mathrm{~m}, \\
\text { topo } 150 \mathrm{~m} \text {, riparian } 150 \mathrm{p}, \text { urban } 150 \mathrm{p}\end{array}$ & 8 & 0.929 & 0.71 & 0.71 & 0.73 & 0.69 & 0.73 & 0 \\
\hline
\end{tabular}


Table 2.1. Twenty top performing Least Bell's Vireo habitat suitability models based on the area under the curve (AUC) metric and median habitat similarity index () values for randomly selected model construction and evaluation datasets, the 2016 (average rainfall), 2017 (above average rainfall), and 2018 (below average rainfall) evaluation datasets, and the randomly selected pseudo-absence dataset.-Continued

[The selected model is highlighted in gray and performs well predicting suitable habitat in the current southern California range and is the top model predicting habitat in the historic range in California. Abbreviations: AUC, area under the curve; HSI, habitat similarity index; CWD, cumulative water deficit]

\begin{tabular}{|c|c|c|c|c|c|c|c|c|c|c|}
\hline $\begin{array}{l}\text { Model } \\
\text { number- } \\
\text { partition }\end{array}$ & Model type & Model variables & $\begin{array}{l}\text { Number } \\
\text { of } \\
\text { variables }\end{array}$ & AUC & $\begin{array}{l}\text { Median } \\
\text { random } \\
\text { calibration } \\
\text { HSI }\end{array}$ & $\begin{array}{c}\text { Random } \\
\text { dataset } \\
\text { HSI }\end{array}$ & $\begin{array}{l}2016 \\
\text { validation } \\
\text { HSI }\end{array}$ & $\begin{array}{l}2017 \\
\text { validation } \\
\text { HSI }\end{array}$ & $\begin{array}{l}2018 \\
\text { validation } \\
\text { HSI }\end{array}$ & $\begin{array}{c}\text { Pseudo- } \\
\text { absence } \\
\text { validation } \\
\text { HSI }\end{array}$ \\
\hline R4-P1 & $\begin{array}{l}\text { Winter climate, topography, } \\
\text { local-scale riparian, urbanization } \\
\text { and NDVI, distance to water and } \\
\text { annual CWD }\end{array}$ & $\begin{array}{l}\text { prec_OD_av, minT_OD_av, maxT_- } \\
\text { OD_av, dem } 150 \mathrm{~m}, \text { slope } 150 \mathrm{~m}, \\
\text { topo } 150 \mathrm{~m} \text {, flat } 150 \mathrm{~m} \text {, riparian } 150 \mathrm{p}, \\
\text { urban } 150 \mathrm{p}, \text { NDVImax } 150, \\
\text { waterdistm, cwd_anntot }\end{array}$ & 12 & 0.929 & 0.73 & 0.71 & 0.70 & 0.66 & 0.70 & 0 \\
\hline R22-P1 & $\begin{array}{l}\text { Pre-breeding climate, topography, } \\
\text { local-scale riparian and } \\
\text { urbanization, distance to water and } \\
\text { annual CWD }\end{array}$ & $\begin{array}{l}\text { prec_JM_av, minT_JM_av, maxT__ } \\
\text { JM_av, dem } 150 \mathrm{~m} \text {, slope } 150 \mathrm{~m}, \\
\text { topo } 150 \mathrm{~m} \text {, flat } 150 \mathrm{~m} \text {, riparian } 150 \mathrm{p}, \\
\text { urban } 150 \mathrm{p} \text {, waterdistm, cwd_anntot }\end{array}$ & 11 & 0.928 & 0.73 & 0.71 & 0.74 & 0.74 & 0.69 & 0 \\
\hline R13-P1 & $\begin{array}{l}\text { Winter climate, topography, } \\
\text { landscape-scale riparian, } \\
\text { urbanization and NDVI, distance to } \\
\text { water and annual CWD }\end{array}$ & $\begin{array}{l}\text { prec_OD_av, minT_OD_av, maxT_- } \\
\text { OD_av, dem } 150 \mathrm{~m} \text {, slope } 150 \mathrm{~m}, \\
\text { topo } 150 \mathrm{~m} \text {, flat } 150 \mathrm{~m} \text {, riparian } 500 \mathrm{p}, \\
\text { urban } 500 \mathrm{p}, \text { NDVI } 25 \mathrm{p} 500 \\
\text { waterdistm, cwd_anntot }\end{array}$ & 12 & 0.928 & 0.72 & 0.70 & 0.72 & 0.69 & 0.67 & 0 \\
\hline R3-P1 & $\begin{array}{l}\text { Breeding climate, topography, } \\
\text { local-scale riparian, urbanization } \\
\text { and NDVI, distance to water and } \\
\text { annual CWD }\end{array}$ & $\begin{array}{l}\text { prec_AJ_av, minT_AJ_av, maxT_ } \\
\text { AJ_av, dem150m, slope } 150 \mathrm{~m}, \\
\text { topo } 150 \mathrm{~m} \text {, flat } 150 \mathrm{~m} \text {, riparian } 150 \mathrm{p}, \\
\text { urban } 150 \mathrm{p}, \text { NDVImean } 150, \\
\text { waterdistm, cwd_anntot }\end{array}$ & 12 & 0.922 & 0.71 & 0.70 & 0.71 & 0.62 & 0.67 & 0 \\
\hline R6-P1 & $\begin{array}{l}\text { Breeding climate, topography, } \\
\text { local-scale riparian, urbanization } \\
\text { and NDVI, distance to water and } \\
\text { annual CWD }\end{array}$ & $\begin{array}{l}\text { prec_AJ_av, minT_AJ_av, maxT_} \\
\text { AJ_av, dem150m, slope150m, } \\
\text { topo } 150 \mathrm{~m}, \text { flat } 150 \mathrm{~m} \text {, riparian } 150 \mathrm{p}, \\
\text { urban } 150 \mathrm{p}, \text { NDVImax } 150, \\
\text { waterdistm, cwd_anntot }\end{array}$ & 12 & 0.919 & 0.73 & 0.71 & 0.67 & 0.62 & 0.66 & 0 \\
\hline $\mathrm{R} 25-\mathrm{P} 1$ & $\begin{array}{l}\text { Annual precipitation, topography, } \\
\text { local-scale riparian, distance to } \\
\text { water and annual CWD }\end{array}$ & $\begin{array}{l}\text { prec_anntot, slope } 150 \mathrm{~m} \text {, topo } 150 \mathrm{~m} \text {, } \\
\text { flat } 150 \mathrm{~m} \text {, riparian } 150 \mathrm{p}, \\
\text { waterdistm,cwd_anntot }\end{array}$ & 7 & 0.919 & 0.68 & 0.68 & 0.63 & 0.58 & 0.59 & 0 \\
\hline R24-P1 & $\begin{array}{l}\text { Annual precipitation, topography, } \\
\text { local-scale riparian, landscape-scale } \\
\text { NDVI, distance to water and annual } \\
\text { CWD }\end{array}$ & $\begin{array}{l}\text { prec_anntot, slope } 150 \mathrm{~m} \text {, topo } 150 \mathrm{~m} \text {, } \\
\text { flat } 150 \mathrm{~m} \text {, riparian } 150 \mathrm{p}, \\
\text { NDVI } 25 \mathrm{p} 500 \text {, waterdistm, cwd_ } \\
\text { anntot }\end{array}$ & 8 & 0.914 & 0.69 & 0.68 & 0.68 & 0.61 & 0.61 & 0 \\
\hline
\end{tabular}
CWD anntot 
Table 2.1. Twenty top performing Least Bell's Vireo habitat suitability models based on the area under the curve (AUC) metric and median habitat similarity index () values for randomly selected model construction and evaluation datasets, the 2016 (average rainfall), 2017 (above average rainfall), and 2018 (below average rainfall) evaluation datasets, and the randomly selected pseudo-absence dataset.-Continued

[The selected model is highlighted in gray and performs well predicting suitable habitat in the current southern California range and is the top model predicting habitat in the historic range in California. Abbreviations: AUC, area under the curve; HSI, habitat similarity index; CWD, cumulative water deficit]

\begin{tabular}{|c|c|c|c|c|c|c|c|c|c|c|}
\hline $\begin{array}{l}\text { Model } \\
\text { number- } \\
\text { partition }\end{array}$ & Model type & Model variables & $\begin{array}{c}\text { Number } \\
\text { of } \\
\text { variables }\end{array}$ & AUC & $\begin{array}{l}\text { Median } \\
\text { random } \\
\text { calibration } \\
\text { HSI }\end{array}$ & $\begin{array}{c}\text { Random } \\
\text { dataset } \\
\text { HSI }\end{array}$ & $\begin{array}{c}2016 \\
\text { validation } \\
\text { HSI }\end{array}$ & $\begin{array}{c}2017 \\
\text { validation } \\
\text { HSI }\end{array}$ & $\begin{array}{c}2018 \\
\text { validation } \\
\text { HSI }\end{array}$ & $\begin{array}{c}\text { Pseudo- } \\
\text { absence } \\
\text { validation } \\
\text { HSI }\end{array}$ \\
\hline R28-P1 & $\begin{array}{l}\text { Topography, local-scale riparian, } \\
\text { distance to water and annual CWD }\end{array}$ & $\begin{array}{l}\text { slope } 150 \mathrm{~m} \text {, topo } 150 \mathrm{~m} \text {, flat } 150 \mathrm{~m} \text {, } \\
\text { riparian } 150 \mathrm{p} \text {, waterdistm, cwd_ } \\
\text { anntot }\end{array}$ & 6 & 0.914 & 0.68 & 0.67 & 0.63 & 0.63 & 0.57 & 0 \\
\hline R26-P1 & $\begin{array}{l}\text { Pre-breeding precipitation, } \\
\text { topography, local-scale riparian, } \\
\text { landscape-scale NDVI, distance to } \\
\text { water and annual CWD }\end{array}$ & $\begin{array}{l}\text { prec_JM_av, slope } 150 \mathrm{~m} \text {, topo } 150 \mathrm{~m} \text {, } \\
\text { flat } 150 \mathrm{~m} \text {, riparian } 150 \mathrm{p}, \\
\text { NDVI } 25 \mathrm{p} 500 \text {, waterdistm, cwd_ } \\
\text { anntot }\end{array}$ & 8 & 0.911 & 0.70 & 0.68 & 0.69 & 0.61 & 0.61 & 0 \\
\hline R14-P1 & $\begin{array}{l}\text { Pre-breeding climate, topography, } \\
\text { local-scale riparian and } \\
\text { urbanization, landscape-scale } \\
\text { NDVI, distance to water and annual } \\
\text { CWD }\end{array}$ & $\begin{array}{l}\text { prec_JM_av, minT_JM_av, maxT_ } \\
\text { JM_av, dem } 150 \mathrm{~m} \text {, slope } 150 \mathrm{~m}, \\
\text { topo } 150 \mathrm{~m} \text {, flat } 150 \mathrm{~m} \text {, riparian } 150 \mathrm{p}, \\
\text { urban } 150 \mathrm{p}, \text { NDVI } 25 \mathrm{p} 500, \\
\text { waterdistm, cwd_anntot }\end{array}$ & 12 & 0.911 & 0.69 & 0.67 & 0.70 & 0.66 & 0.62 & 0 \\
\hline R12-P1 & $\begin{array}{l}\text { Breeding climate, topography, } \\
\text { landscape-scale riparian, } \\
\text { urbanization and NDVI, distance to } \\
\text { water and annual CWD }\end{array}$ & $\begin{array}{l}\text { prec_AJ_av, minT_AJ_av, maxT_ } \\
\text { AJ_av, dem } 150 \mathrm{~m}, \text { slope } 150 \mathrm{~m}, \\
\text { topo } 150 \mathrm{~m} \text {, flat } 150 \mathrm{~m} \text {, riparian } 500 \mathrm{p}, \\
\text { urban500p, NDVImax } 500, \\
\text { waterdistm, cwd_anntot }\end{array}$ & 12 & 0.910 & 0.70 & 0.68 & 0.62 & 0.54 & 0.61 & 0 \\
\hline R27-P1 & $\begin{array}{l}\text { Topography, local-scale riparian, } \\
\text { landscape-scale NDVI, distance to } \\
\text { water and annual CWD }\end{array}$ & $\begin{array}{l}\text { slope } 150 \mathrm{~m} \text {, topo } 150 \mathrm{~m} \text {, flat } 150 \mathrm{~m} \text {, } \\
\text { riparian } 150 \mathrm{p}, \text { NDVI } 25 \mathrm{p} 500, \\
\text { waterdistm, cwd_anntot }\end{array}$ & 7 & 0.907 & 0.71 & 0.70 & 0.67 & 0.65 & 0.60 & 0 \\
\hline R15-P1 & $\begin{array}{l}\text { Breeding climate, topography, } \\
\text { landscape-scale riparian, } \\
\text { urbanization and NDVI, distance to } \\
\text { water and annual CWD }\end{array}$ & $\begin{array}{l}\text { prec_AJ_av, minT_AJ_av, maxT_ } \\
\text { AJ_av, dem } 150 \mathrm{~m}, \text { slope } 150 \mathrm{~m}, \\
\text { topo } 150 \mathrm{~m} \text {, flat } 150 \mathrm{~m} \text {, riparian } 500 \mathrm{p}, \\
\text { urban500p, NDVI25p500, } \\
\text { waterdistm, cwd_anntot }\end{array}$ & 12 & 0.902 & 0.70 & 0.69 & 0.70 & 0.67 & 0.65 & 0 \\
\hline
\end{tabular}




\section{Appendix 3. Suitable Habitat in California and Conservation Levels by County and Hydrological Unit Code 8 Watersheds}

Table 3.1. Amount of suitable habitat predicted by model R30-P1 and conserved in the Least Bell's Vireo current and historic range in California.

[Hectares (acres) of suitable habitat and vireo detection history are listed by county, hydrological unit code (HUC) 8 watersheds, and associated major rivers and streams. Abbreviations: $<$, less than; $\geq$, greater than or equal to]

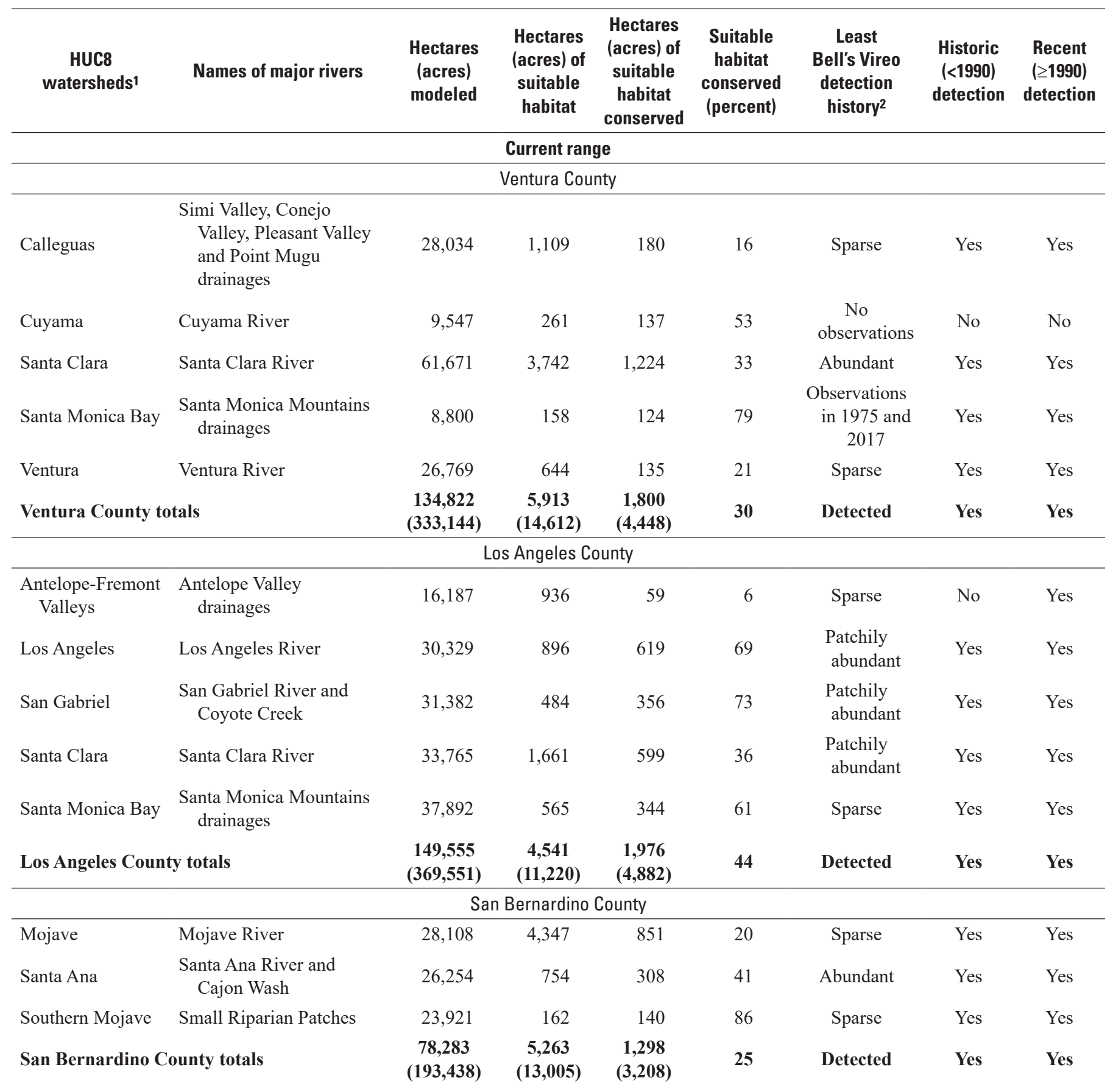


Table 3.1. Amount of suitable habitat predicted by model R30-P1 and conserved in the Least Bell's Vireo current and historic range in California.-Continued

[Hectares (acres) of suitable habitat and vireo detection history are listed by county, hydrological unit code (HUC) 8 watersheds, and associated major rivers and streams. Abbreviations: $<$, less than; $\geq$, greater than or equal to]

\begin{tabular}{|c|c|c|c|c|c|c|c|c|}
\hline $\begin{array}{c}\text { HUC8 } \\
\text { watersheds } 1\end{array}$ & Names of major rivers & $\begin{array}{l}\text { Hectares } \\
\text { (acres) } \\
\text { modeled }\end{array}$ & $\begin{array}{l}\text { Hectares } \\
\text { (acres) of } \\
\text { suitable } \\
\text { habitat }\end{array}$ & $\begin{array}{l}\text { Hectares } \\
\text { (acres) of } \\
\text { suitable } \\
\text { habitat } \\
\text { conserved }\end{array}$ & $\begin{array}{l}\text { Suitable } \\
\text { habitat } \\
\text { conserved } \\
\text { (percent) }\end{array}$ & $\begin{array}{l}\text { Least } \\
\text { Bell's Vireo } \\
\text { detection } \\
\text { history2 }\end{array}$ & $\begin{array}{l}\text { Historic } \\
(<1990) \\
\text { detection }\end{array}$ & $\begin{array}{c}\text { Recent } \\
(\geq 1990) \\
\text { detection }\end{array}$ \\
\hline \multicolumn{9}{|c|}{ Current range-Continued } \\
\hline \multicolumn{9}{|c|}{ Riverside County } \\
\hline San Felipe Creek & Coyote Creek & 3,148 & 59 & 34 & 58 & Sparse & Yes & Yes \\
\hline San Jacinto & San Jacinto River & 44,791 & 1,906 & 659 & 35 & Common & Yes & Yes \\
\hline Santa Ana & Santa Ana River & 52,031 & 4,932 & 1,859 & 38 & Abundant & Yes & Yes \\
\hline Santa Margarita & Santa Margarita River & 45,868 & 2,565 & 371 & 14 & Common & Yes & Yes \\
\hline Riverside County & cotals & $\begin{array}{c}183,154 \\
(452,573)\end{array}$ & $\begin{array}{c}10,902 \\
(26,938)\end{array}$ & $\begin{array}{c}3,877 \\
(9,580)\end{array}$ & 29 & Detected & Yes & Yes \\
\hline \multicolumn{9}{|c|}{ Orange County } \\
\hline Aliso-San Onofre & $\begin{array}{l}\text { Cristianitos, San Juan, } \\
\text { Arroyo Trabuco, } \\
\text { Wood, Aliso, and } \\
\text { Laguna Canyons }\end{array}$ & 24,409 & 2,201 & 1,080 & 49 & Common & Yes & Yes \\
\hline Newport Bay & $\begin{array}{l}\text { San Diego and Serrano } \\
\text { Creeks and Aqua } \\
\text { Chinon Wash }\end{array}$ & 9,907 & 900 & 448 & 50 & Common & Yes & Yes \\
\hline \multicolumn{9}{|c|}{ San Diego County } \\
\hline Aliso-San Onofre & $\begin{array}{l}\text { San Onofre, Las Pulgas } \\
\text { and San Mateo } \\
\text { Canyons }\end{array}$ & 19,718 & 1,742 & 56 & 3 & Abundant & Yes & Yes \\
\hline Carrizo Creek & Carrizo Creek & 3,326 & 754 & 749 & 99 & Sparse & No & Yes \\
\hline Carrizo Creek & $\begin{array}{l}\text { Vallecito Creek and Agua } \\
\text { Caliente }\end{array}$ & 1,539 & 268 & 266 & 99 & Common & Yes & Yes \\
\hline $\begin{array}{l}\text { Cottonwood- } \\
\text { Tijuana }\end{array}$ & Tijuana River & 1,681 & 740 & 641 & 87 & Abundant & Yes & Yes \\
\hline $\begin{array}{l}\text { Cottonwood- } \\
\text { Tijuana }\end{array}$ & $\begin{array}{l}\text { Marron Valley, Lower } \\
\text { Cottonwood and } \\
\text { Potrero Creeks, and } \\
\text { Tijuana River }\end{array}$ & 1,888 & 295 & 250 & 85 & Sparse & Yes & Yes \\
\hline $\begin{array}{l}\text { Cottonwood- } \\
\text { Tijuana }\end{array}$ & Hauser Canyon & 644 & 77 & 77 & 100 & Sparse & No & Yes \\
\hline
\end{tabular}


Table 3.1. Amount of suitable habitat predicted by model R30-P1 and conserved in the Least Bell's Vireo current and historic range in California.-Continued

[Hectares (acres) of suitable habitat and vireo detection history are listed by county, hydrological unit code (HUC) 8 watersheds, and associated major rivers and streams. Abbreviations: $<$, less than; $\geq$, greater than or equal to]

\begin{tabular}{|c|c|c|c|c|c|c|c|c|}
\hline $\begin{array}{c}\text { HUC8 } \\
\text { watersheds } 1\end{array}$ & Names of major rivers & $\begin{array}{l}\text { Hectares } \\
\text { (acres) } \\
\text { modeled }\end{array}$ & $\begin{array}{l}\text { Hectares } \\
\text { (acres) of } \\
\text { suitable } \\
\text { habitat }\end{array}$ & $\begin{array}{l}\text { Hectares } \\
\text { (acres) of } \\
\text { suitable } \\
\text { habitat } \\
\text { conserved }\end{array}$ & $\begin{array}{l}\text { Suitable } \\
\text { habitat } \\
\text { conserved } \\
\text { (percent) }\end{array}$ & $\begin{array}{l}\text { Least } \\
\text { Bell's Vireo } \\
\text { detection } \\
\text { history² }\end{array}$ & $\begin{array}{c}\text { Historic } \\
\text { (<1990) } \\
\text { detection }\end{array}$ & $\begin{array}{c}\text { Recent } \\
(\geq 1990) \\
\text { detection }\end{array}$ \\
\hline \multicolumn{9}{|c|}{ Current range-Continued } \\
\hline \multicolumn{9}{|c|}{ San Diego County—Continued } \\
\hline $\begin{array}{l}\text { Cottonwood- } \\
\text { Tijuana }\end{array}$ & $\begin{array}{l}\text { Lake Morena and } \\
\text { Kitchen Creek, Upper } \\
\text { Cottonwood and La } \\
\text { Posta Creeks }\end{array}$ & 4,115 & 317 & 317 & 100 & Sparse & No & Yes \\
\hline San Diego & Otay River & 3,035 & 574 & 261 & 45 & Common & Yes & Yes \\
\hline San Diego & $\begin{array}{l}\text { West Dulzura, Jamul and } \\
\text { Hollenbeck Creeks }\end{array}$ & 2,952 & 270 & 178 & 66 & Common & Yes & Yes \\
\hline San Diego & Sweetwater River & 14,340 & 1,028 & 572 & 56 & Abundant & Yes & Yes \\
\hline San Diego & $\begin{array}{l}\text { Taylor Creek and Upper } \\
\text { Sweetwater River }\end{array}$ & 491 & 27 & 20 & 75 & Sparse & No & Yes \\
\hline San Diego & San Diego River & 14,248 & 1,195 & 594 & 50 & Abundant & Yes & Yes \\
\hline San Diego & $\begin{array}{l}\text { San Clemente and Carroll } \\
\text { Canyons and Rose } \\
\text { Creek }\end{array}$ & 4,750 & 394 & 79 & 20 & Sparse & No & Yes \\
\hline San Diego & Los Penasquitos Canyon & 5,351 & 686 & 497 & 72 & Sparse & No & Yes \\
\hline San Diego & San Dieguito River & 25,653 & 1,440 & 1,015 & 70 & Abundant & Yes & Yes \\
\hline San Felipe Creek & San Felipe Creek & 59,196 & 745 & 722 & 97 & Common & Yes & Yes \\
\hline San Felipe Creek & $\begin{array}{l}\text { Clark Lake, Hellholeand } \\
\text { Borrego Palm } \\
\text { Canyons, Hotsprings } \\
\text { Mountain, Montezuma, } \\
\text { Borrego, and Collins } \\
\text { Valleys }\end{array}$ & 9,466 & 286 & 270 & 94 & Sparse & Yes & Yes \\
\hline $\begin{array}{l}\text { San Luis Rey- } \\
\text { Escondido }\end{array}$ & $\begin{array}{l}\text { Escondido and Encinitas } \\
\text { Creeks }\end{array}$ & 9,048 & 482 & 270 & 56 & Sparse & Yes & Yes \\
\hline $\begin{array}{l}\text { San Luis Rey- } \\
\text { Escondido }\end{array}$ & $\begin{array}{l}\text { Carlsbad between Hwy } \\
78 \text { and Palomar Airport } \\
\text { Road }\end{array}$ & 3,602 & 263 & 176 & 67 & Common & Yes & Yes \\
\hline $\begin{array}{l}\text { San Luis Rey- } \\
\text { Escondido }\end{array}$ & $\begin{array}{l}\text { Vista and San Marcos } \\
\text { drainages from Hwy } \\
78 \text { north to Gopher } \\
\text { Canyon }\end{array}$ & 2,549 & 140 & 23 & 16 & Sparse & No & Yes \\
\hline $\begin{array}{l}\text { San Luis Rey- } \\
\text { Escondido }\end{array}$ & San Luis Rey River & 44,523 & 3,184 & 1,235 & 39 & Abundant & Yes & Yes \\
\hline Santa Margarita & Santa Margarita River & 14,898 & 1,379 & 27 & 2 & Abundant & Yes & Yes \\
\hline San Diego Count & totals & $\begin{array}{c}247,012 \\
(610,366)\end{array}$ & $\begin{array}{c}16,284 \\
(40,238)\end{array}$ & $\begin{array}{c}8,294 \\
(20,494)\end{array}$ & 51 & Detected & Yes & Yes \\
\hline Current range to & & $\begin{array}{c}846,241 \\
(2,091,060)\end{array}$ & $\begin{array}{c}47,171 \\
(116,560)\end{array}$ & $\begin{array}{c}19,526 \\
(48,250)\end{array}$ & 41 & & & \\
\hline
\end{tabular}


Table 3.1. Amount of suitable habitat predicted by model R30-P1 and conserved in the Least Bell's Vireo current and historic range in California.-Continued

[Hectares (acres) of suitable habitat and vireo detection history are listed by county, hydrological unit code (HUC) 8 watersheds, and associated major rivers and streams. Abbreviations: $<$, less than; $\geq$, greater than or equal to]

\begin{tabular}{|c|c|c|c|c|c|c|c|c|}
\hline $\begin{array}{c}\text { HUC8 } \\
\text { watersheds } 1\end{array}$ & Names of major rivers & $\begin{array}{l}\text { Hectares } \\
\text { (acres) } \\
\text { modeled }\end{array}$ & $\begin{array}{c}\text { Hectares } \\
\text { (acres) of } \\
\text { suitable } \\
\text { habitat }\end{array}$ & $\begin{array}{c}\text { Hectares } \\
\text { (acres) of } \\
\text { suitable } \\
\text { habitat } \\
\text { conserved }\end{array}$ & $\begin{array}{c}\text { Suitable } \\
\text { habitat } \\
\text { conserved } \\
\text { (percent) }\end{array}$ & $\begin{array}{c}\text { Least } \\
\text { Bell's Vireo } \\
\text { detection } \\
\text { history2 }\end{array}$ & $\begin{array}{c}\text { Historic } \\
\text { (<1990) } \\
\text { detection }\end{array}$ & $\begin{array}{l}\text { Recent } \\
(\geq 1990) \\
\text { detection }\end{array}$ \\
\hline \multicolumn{9}{|c|}{ Historic range } \\
\hline \multicolumn{9}{|c|}{ Shasta County } \\
\hline Battle Creek & Battle Creek & 12,931 & 236 & 27 & 11 & $\begin{array}{c}\text { No } \\
\text { observations }\end{array}$ & No & No \\
\hline $\begin{array}{l}\text { Clear Creek- } \\
\text { Sacramento } \\
\text { River }\end{array}$ & $\begin{array}{l}\text { Sacramento River and } \\
\text { Clear Creek }\end{array}$ & 47,704 & 3,170 & 554 & 17 & $\begin{array}{c}\text { No } \\
\text { observations }\end{array}$ & No & No \\
\hline $\begin{array}{l}\text { Cottonwood } \\
\text { Creek }\end{array}$ & Cottonwood Creek & 17,616 & 790 & 0 & 0 & $\begin{array}{c}\text { No } \\
\text { observations }\end{array}$ & No & No \\
\hline Cow Creek & Cow Creek & 37,714 & 1,598 & 304 & 19 & $\begin{array}{c}\text { No } \\
\text { observations }\end{array}$ & No & No \\
\hline Lower Pit & Pit River & 69,944 & 1,807 & 374 & 21 & $\begin{array}{c}\text { No } \\
\text { observations }\end{array}$ & No & No \\
\hline McCloud & McCloud River & 20,242 & 248 & 52 & 21 & $\begin{array}{c}\text { No } \\
\text { observations }\end{array}$ & No & No \\
\hline $\begin{array}{l}\text { Sacramento } \\
\text { Headwaters }\end{array}$ & Upper Sacramento River & 23,095 & 281 & 56 & 20 & $\begin{array}{c}\text { No } \\
\text { observations }\end{array}$ & No & No \\
\hline Shasta County to & & $\begin{array}{c}229,247 \\
(566,469)\end{array}$ & $\begin{array}{c}8,130 \\
(20,088)\end{array}$ & $\begin{array}{c}1,366 \\
(3,375)\end{array}$ & 17 & Undetected & No & No \\
\hline \multicolumn{9}{|c|}{ Tehama County } \\
\hline Battle Creek & Battle Creek & 13,843 & 425 & 185 & 43 & $\begin{array}{c}\text { No } \\
\text { observations }\end{array}$ & No & No \\
\hline $\begin{array}{l}\text { Big Chico Creek- } \\
\text { Sacramento } \\
\text { River }\end{array}$ & $\begin{array}{l}\text { Sacramento River and } \\
\text { Big Chico Creek }\end{array}$ & 48,908 & 3,024 & 475 & 16 & $\begin{array}{c}\text { No } \\
\text { observations }\end{array}$ & No & No \\
\hline $\begin{array}{l}\text { Clear Creek and } \\
\text { Sacramento } \\
\text { River }\end{array}$ & $\begin{array}{l}\text { Sacramento River and } \\
\text { Clear Creek }\end{array}$ & 347 & 108 & 61 & 56 & $\begin{array}{c}\text { Observation in } \\
1926\end{array}$ & Yes & No \\
\hline $\begin{array}{l}\text { Cottonwood } \\
\text { Creek }\end{array}$ & Cottonwood Creek & 18,955 & 1,157 & 41 & 4 & $\begin{array}{c}\text { No } \\
\text { observations }\end{array}$ & No & No \\
\hline $\begin{array}{l}\text { Paynes Creek- } \\
\text { Sacramento } \\
\text { River }\end{array}$ & $\begin{array}{l}\text { Sacramento River and } \\
\text { Paynes Creek }\end{array}$ & 16,394 & 2,223 & 106 & 5 & $\begin{array}{c}\text { Five } \\
\text { observations } \\
\text { in 1920s }\end{array}$ & Yes & No \\
\hline $\begin{array}{l}\text { Thomes Creek- } \\
\text { Sacramento } \\
\text { River }\end{array}$ & $\begin{array}{l}\text { Sacramento River and } \\
\text { Thomes Creek }\end{array}$ & 62,803 & 4,484 & 245 & 5 & $\begin{array}{c}\text { Two } \\
\text { observations } \\
\text { in early } \\
1900 \mathrm{~s}\end{array}$ & Yes & No \\
\hline \multicolumn{2}{|c|}{ Tehama County totals } & $\begin{array}{c}161,249 \\
(398,446)\end{array}$ & $\begin{array}{c}11,422 \\
(28,223)\end{array}$ & $\begin{array}{c}1,112 \\
(2,747)\end{array}$ & 10 & Detected & Yes & No \\
\hline
\end{tabular}


Table 3.1. Amount of suitable habitat predicted by model R30-P1 and conserved in the Least Bell's Vireo current and historic range in California.-Continued

[Hectares (acres) of suitable habitat and vireo detection history are listed by county, hydrological unit code (HUC) 8 watersheds, and associated major rivers and streams. Abbreviations: $<$, less than; $\geq$, greater than or equal to]

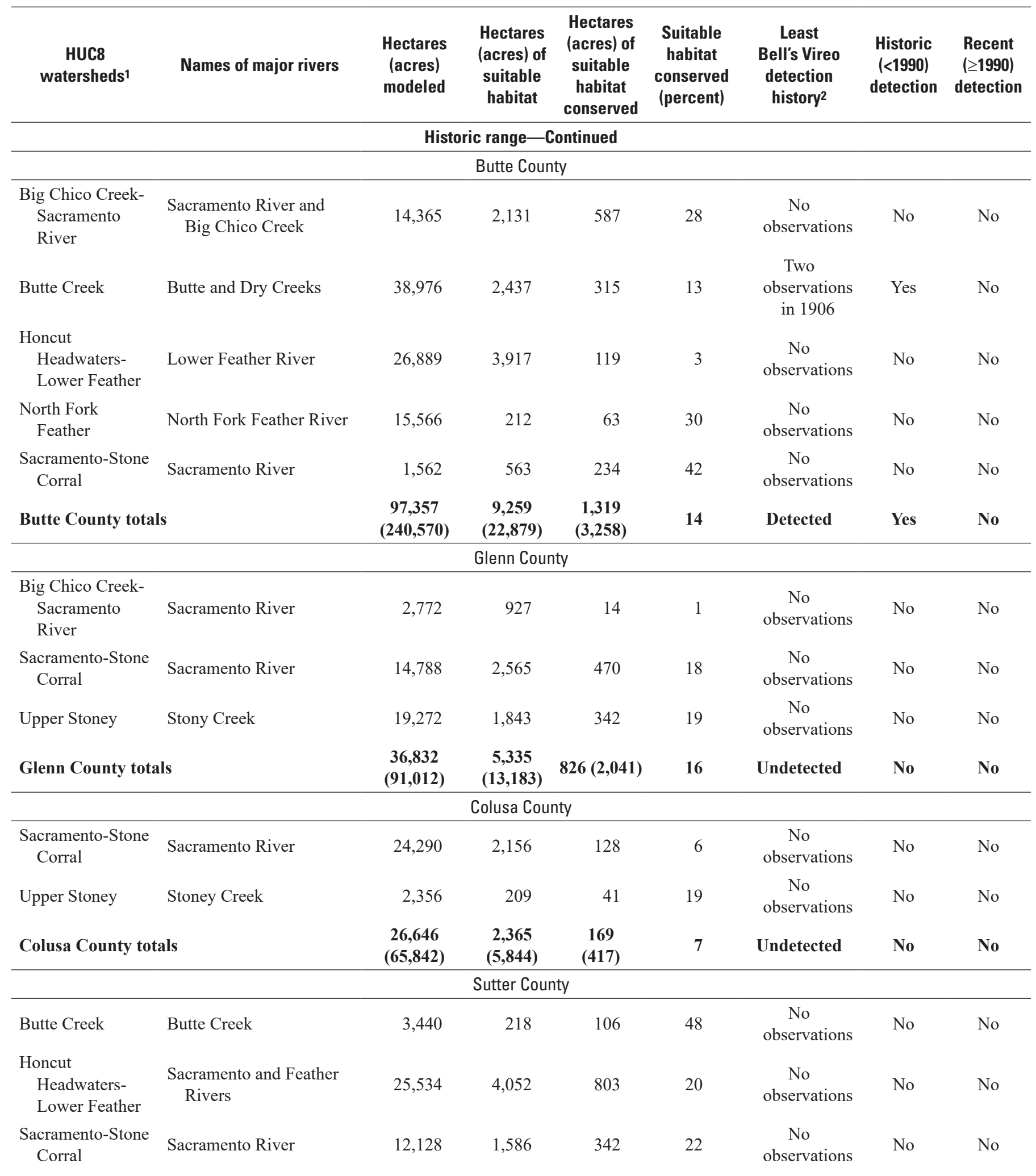


Table 3.1. Amount of suitable habitat predicted by model R30-P1 and conserved in the Least Bell's Vireo current and historic range in California.-Continued

[Hectares (acres) of suitable habitat and vireo detection history are listed by county, hydrological unit code (HUC) 8 watersheds, and associated major rivers and streams. Abbreviations: $<$, less than; $\geq$, greater than or equal to]

\begin{tabular}{|c|c|c|c|c|c|c|c|c|}
\hline $\begin{array}{c}\text { HUC8 } \\
\text { watersheds }{ }^{1}\end{array}$ & Names of major rivers & $\begin{array}{l}\text { Hectares } \\
\text { (acres) } \\
\text { modeled }\end{array}$ & $\begin{array}{c}\text { Hectares } \\
\text { (acres) of } \\
\text { suitable } \\
\text { habitat }\end{array}$ & $\begin{array}{l}\text { Hectares } \\
\text { (acres) of } \\
\text { suitable } \\
\text { habitat } \\
\text { conserved }\end{array}$ & $\begin{array}{c}\text { Suitable } \\
\text { habitat } \\
\text { conserved } \\
\text { (percent) }\end{array}$ & $\begin{array}{l}\text { Least } \\
\text { Bell's Vireo } \\
\text { detection } \\
\text { history² }\end{array}$ & $\begin{array}{c}\text { Historic } \\
\text { (<1990) } \\
\text { detection }\end{array}$ & $\begin{array}{c}\text { Recent } \\
(\geq 1990) \\
\text { detection }\end{array}$ \\
\hline \multicolumn{9}{|c|}{ Historic range-Continued } \\
\hline \multicolumn{9}{|c|}{ Sutter County-Continued } \\
\hline Upper Bear & Yankee Slough & 1,229 & 124 & 7 & 5 & $\begin{array}{c}\text { No } \\
\text { observations }\end{array}$ & No & No \\
\hline $\begin{array}{l}\text { Upper Coon- } \\
\text { Upper Auburn }\end{array}$ & Coon Creek & 7,738 & 236 & 7 & 3 & $\begin{array}{c}\text { No } \\
\text { observations }\end{array}$ & No & No \\
\hline Sutter County tota & & $\begin{array}{c}50,069 \\
(123,721)\end{array}$ & $\begin{array}{c}6,217 \\
(15,362)\end{array}$ & $\begin{array}{c}1,265 \\
(3,125)\end{array}$ & 20 & Undetected & No & No \\
\hline \multicolumn{9}{|c|}{ Yuba County } \\
\hline $\begin{array}{l}\text { Honcut } \\
\text { Headwaters- } \\
\text { Lower Feather }\end{array}$ & Feather River & 23,644 & 2,156 & 484 & 22 & $\begin{array}{c}\text { Observation in } \\
1878\end{array}$ & Yes & No \\
\hline Upper Bear & Dry Creek & 7,878 & 763 & 126 & 17 & $\begin{array}{c}\text { No } \\
\text { observations }\end{array}$ & No & No \\
\hline Upper Yuba & Yuba River & 17,002 & 1,782 & 209 & 12 & $\begin{array}{c}\text { No } \\
\text { observations }\end{array}$ & No & No \\
\hline Yuba County total & & $\begin{array}{c}48,523 \\
(119,901)\end{array}$ & $\begin{array}{c}4,700 \\
(11,615)\end{array}$ & $819(2,024)$ & 17 & Detected & Yes & No \\
\hline \multicolumn{9}{|c|}{ Nevada County } \\
\hline Upper Bear & Bear River & 21,149 & 711 & 43 & 6 & $\begin{array}{c}\text { No } \\
\text { observations }\end{array}$ & No & No \\
\hline Upper Yuba & Yuba River & 46,694 & 560 & 25 & 4 & $\begin{array}{c}\text { No } \\
\text { observations }\end{array}$ & No & No \\
\hline Nevada County to & & $\begin{array}{c}67,843 \\
(167,640)\end{array}$ & $\begin{array}{c}1,271 \\
(3,141)\end{array}$ & $\begin{array}{c}68 \\
(167)\end{array}$ & 5 & Undetected & No & No \\
\hline \multicolumn{9}{|c|}{ Placer County } \\
\hline Lower American & American River & 11,885 & 1,150 & 160 & 14 & $\begin{array}{c}\text { No } \\
\text { observations }\end{array}$ & No & No \\
\hline $\begin{array}{l}\text { North Fork } \\
\text { American }\end{array}$ & $\begin{array}{l}\text { North Fork American } \\
\text { River }\end{array}$ & 91,359 & 698 & 407 & 58 & $\begin{array}{c}\text { No } \\
\text { observations }\end{array}$ & No & No \\
\hline Upper Bear & Bear River & 9,615 & 473 & 45 & 10 & $\begin{array}{c}\text { No } \\
\text { observations }\end{array}$ & No & No \\
\hline $\begin{array}{l}\text { Upper Coon- } \\
\text { Upper Auburn }\end{array}$ & Coon Creek & 32,433 & 2,556 & 149 & 6 & $\begin{array}{c}\text { No } \\
\text { observations }\end{array}$ & No & No \\
\hline Placer County tota & & $\begin{array}{c}145,291 \\
(359,015)\end{array}$ & $\begin{array}{c}4,876 \\
(12,049)\end{array}$ & $761(1,879)$ & 16 & Undetected & No & No \\
\hline \multicolumn{9}{|c|}{ Yolo County } \\
\hline $\begin{array}{l}\text { Lower } \\
\text { Sacramento }\end{array}$ & $\begin{array}{l}\text { Sacramento River, } \\
\text { Willow Slough and } \\
\text { Sacramento River } \\
\text { Delta }\end{array}$ & 29,157 & 2,444 & 421 & 17 & $\begin{array}{c}\text { Several recent } \\
\text { and } 1877 \\
\text { observations }\end{array}$ & Yes & Yes \\
\hline $\begin{array}{l}\text { Sacramento-Stone } \\
\text { Corral }\end{array}$ & Oat Creek & 7,414 & 470 & 27 & 6 & $\begin{array}{c}\text { No } \\
\text { observations }\end{array}$ & No & No \\
\hline
\end{tabular}


Table 3.1. Amount of suitable habitat predicted by model R30-P1 and conserved in the Least Bell's Vireo current and historic range in California.-Continued

[Hectares (acres) of suitable habitat and vireo detection history are listed by county, hydrological unit code (HUC) 8 watersheds, and associated major rivers and streams. Abbreviations: $<$, less than; $\geq$, greater than or equal to]

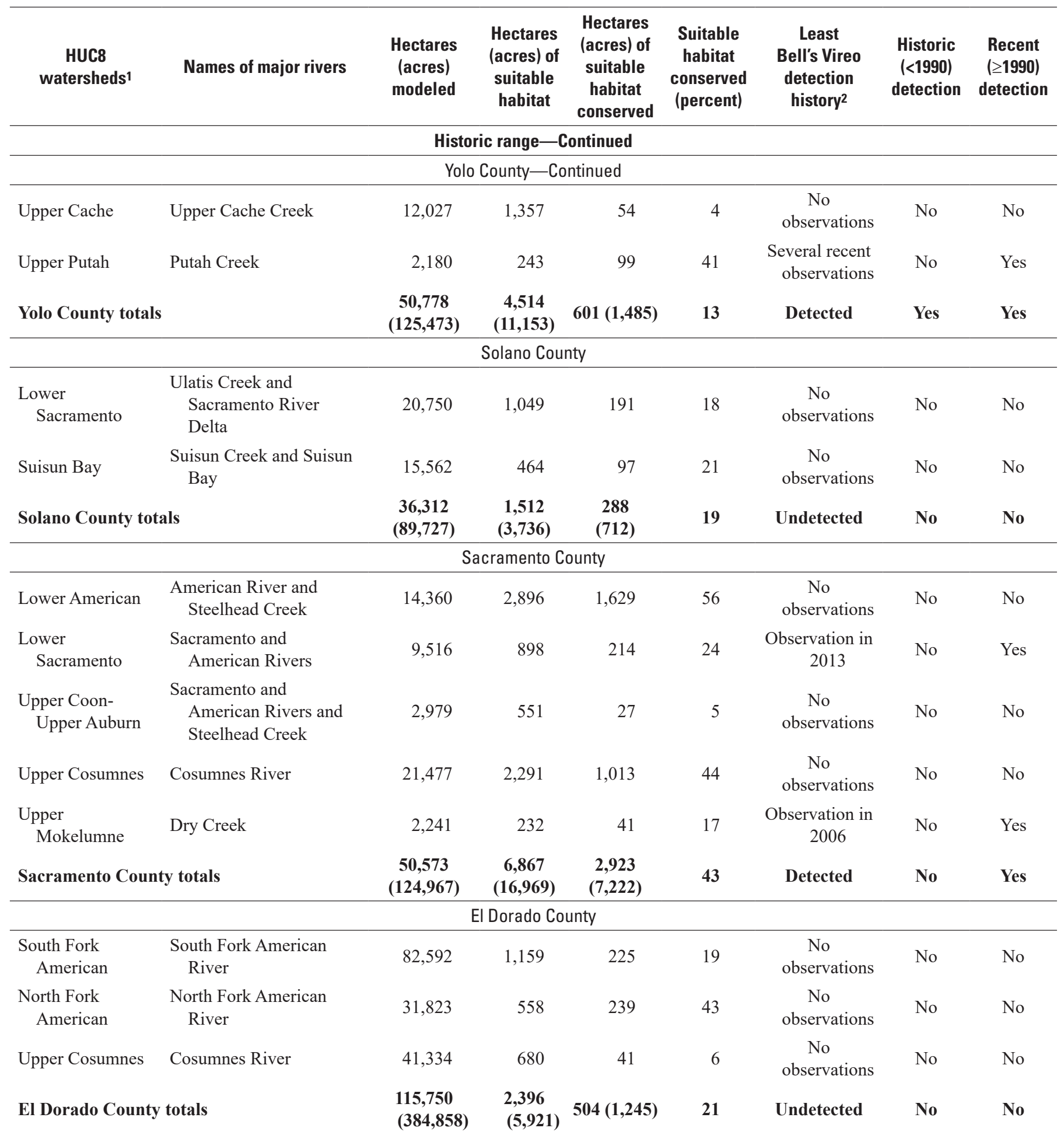


Table 3.1. Amount of suitable habitat predicted by model R30-P1 and conserved in the Least Bell's Vireo current and historic range in California.-Continued

[Hectares (acres) of suitable habitat and vireo detection history are listed by county, hydrological unit code (HUC) 8 watersheds, and associated major rivers and streams. Abbreviations: $<$, less than; $\geq$, greater than or equal to]

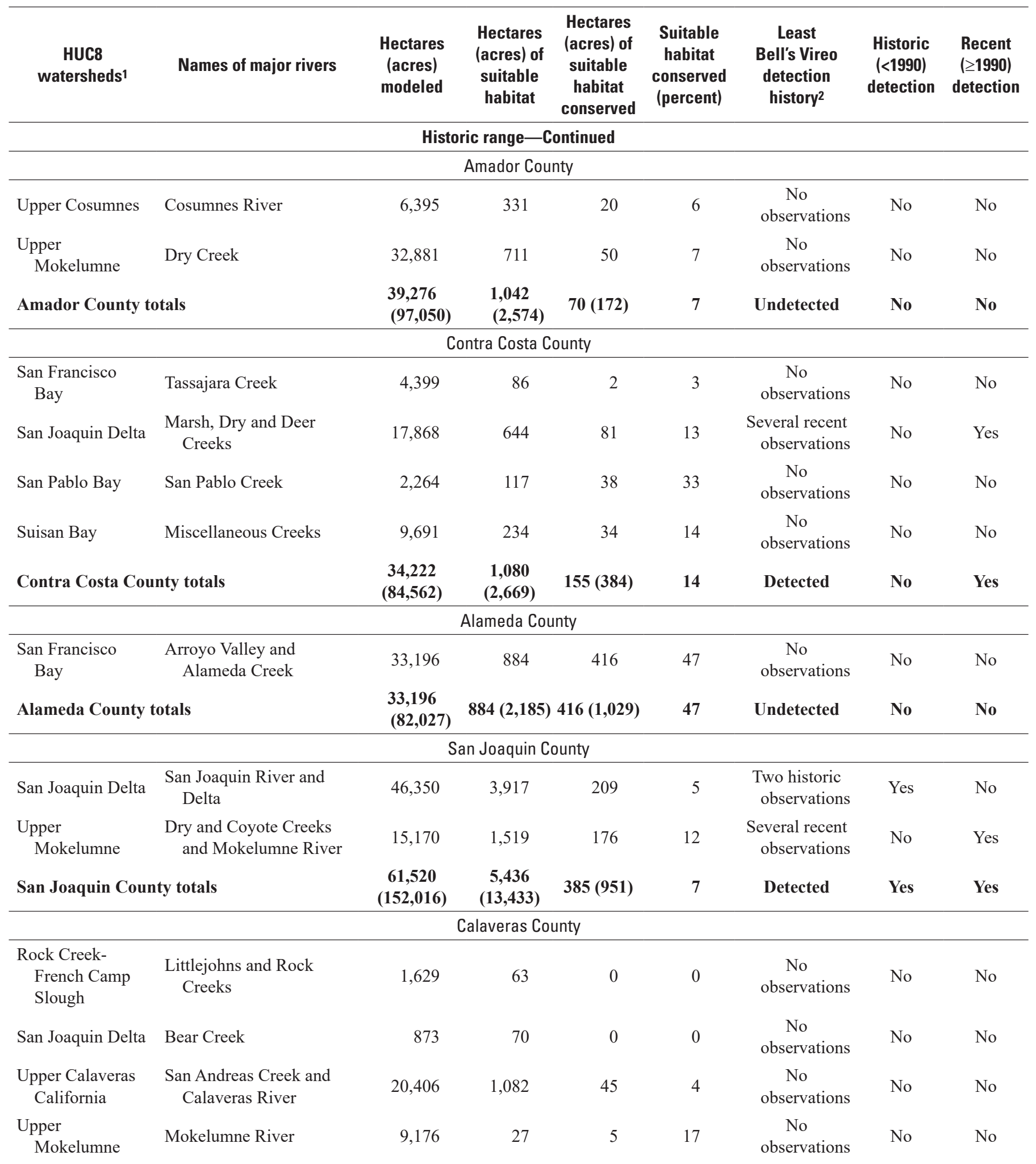


Table 3.1. Amount of suitable habitat predicted by model R30-P1 and conserved in the Least Bell's Vireo current and historic range in California.-Continued

[Hectares (acres) of suitable habitat and vireo detection history are listed by county, hydrological unit code (HUC) 8 watersheds, and associated major rivers and streams. Abbreviations: $<$, less than; $\geq$, greater than or equal to]

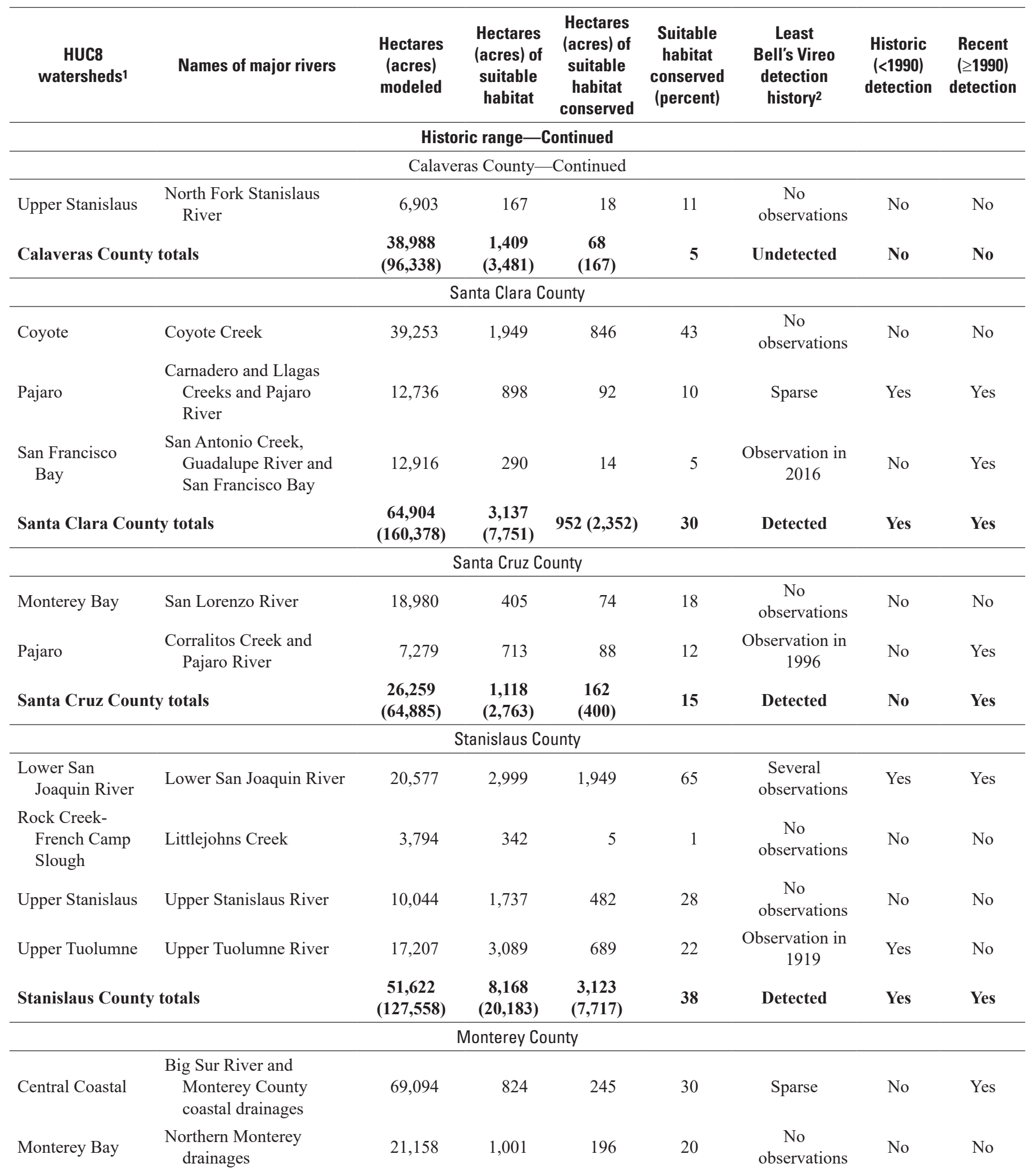


Table 3.1. Amount of suitable habitat predicted by model R30-P1 and conserved in the Least Bell's Vireo current and historic range in California.-Continued

[Hectares (acres) of suitable habitat and vireo detection history are listed by county, hydrological unit code (HUC) 8 watersheds, and associated major rivers and streams. Abbreviations: $<$, less than; $\geq$, greater than or equal to]

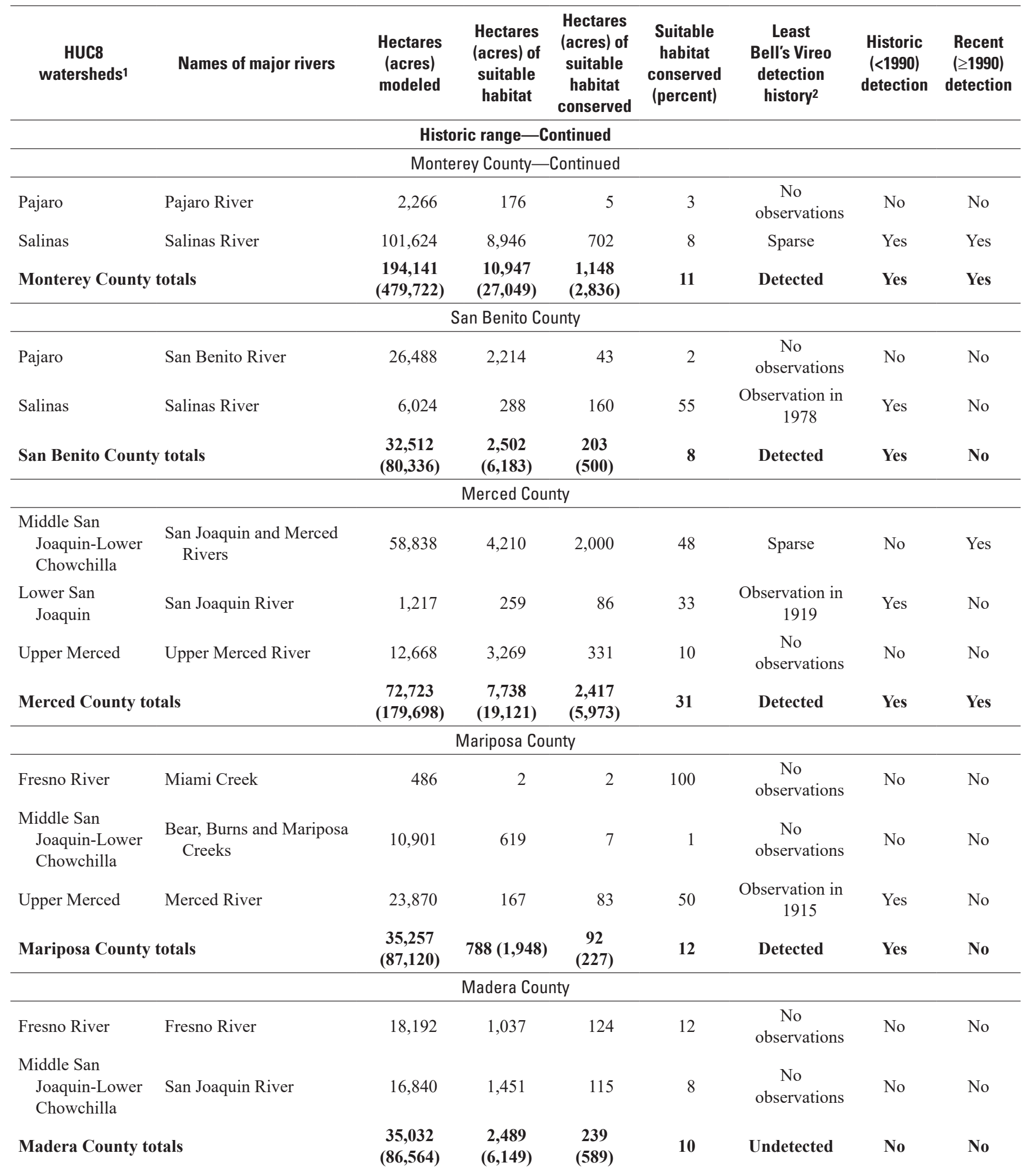


Table 3.1. Amount of suitable habitat predicted by model R30-P1 and conserved in the Least Bell's Vireo current and historic range in California.-Continued

[Hectares (acres) of suitable habitat and vireo detection history are listed by county, hydrological unit code (HUC) 8 watersheds, and associated major rivers and streams. Abbreviations: $<$, less than; $\geq$, greater than or equal to]

\begin{tabular}{|c|c|c|c|c|c|c|c|c|}
\hline $\begin{array}{c}\text { HUC8 } \\
\text { watersheds } 1\end{array}$ & Names of major rivers & $\begin{array}{l}\text { Hectares } \\
\text { (acres) } \\
\text { modeled }\end{array}$ & $\begin{array}{c}\text { Hectares } \\
\text { (acres) of } \\
\text { suitable } \\
\text { habitat }\end{array}$ & $\begin{array}{c}\text { Hectares } \\
\text { (acres) of } \\
\text { suitable } \\
\text { habitat } \\
\text { conserved }\end{array}$ & $\begin{array}{c}\text { Suitable } \\
\text { habitat } \\
\text { conserved } \\
\text { (percent) }\end{array}$ & $\begin{array}{c}\text { Least } \\
\text { Bell's Vireo } \\
\text { detection } \\
\text { history2 }\end{array}$ & $\begin{array}{l}\text { Historic } \\
\text { (<1990) } \\
\text { detection }\end{array}$ & $\begin{array}{c}\text { Recent } \\
(\geq 1990) \\
\text { detection }\end{array}$ \\
\hline \multicolumn{9}{|c|}{ Historic range - Continued } \\
\hline \multicolumn{9}{|c|}{ Fresno County } \\
\hline $\begin{array}{l}\text { Middle San } \\
\text { Joaquin-Lower } \\
\text { Chowchilla }\end{array}$ & San Joaquin River & 10,193 & 529 & 5 & 1 & $\begin{array}{c}\text { Observation in } \\
2006\end{array}$ & No & Yes \\
\hline Tulare Lake Bed & Upper Kings River & 33,767 & 2,945 & 698 & 24 & $\begin{array}{c}\text { No } \\
\text { observations }\end{array}$ & No & No \\
\hline Upper Dry & $\begin{array}{l}\text { San Joaquin River, Sales } \\
\text { and Dog Creeks, and } \\
\text { Fresno Slough }\end{array}$ & 25,858 & 1,193 & 275 & 23 & $\begin{array}{c}\text { Observations } \\
\text { in } 1906 \text { and } \\
1912\end{array}$ & Yes & No \\
\hline Fresno County to & & $\begin{array}{c}69,818 \\
(172,521)\end{array}$ & $\begin{array}{c}4,667 \\
(11,531)\end{array}$ & $977(2,413)$ & 21 & Detected & Yes & Yes \\
\hline \multicolumn{9}{|c|}{ Kings County } \\
\hline Tulare Lake Bed & Kings River & 10,935 & 549 & 18 & 3 & $\begin{array}{c}\text { Observation in } \\
2015\end{array}$ & No & Yes \\
\hline Kings County tot & & $\begin{array}{c}10,935 \\
(27,022) \\
\end{array}$ & $549(1,357)$ & $\begin{array}{c}18 \\
(44)\end{array}$ & 3 & Detected & No & Yes \\
\hline \multicolumn{9}{|c|}{ Tulare County } \\
\hline Upper Kaweah & Upper Kaweah River & 45,992 & 1,197 & 90 & 8 & $\begin{array}{c}\text { No } \\
\text { observations }\end{array}$ & No & No \\
\hline $\begin{array}{l}\text { Upper Deer- } \\
\text { Upper White }\end{array}$ & $\begin{array}{l}\text { White River and Deer } \\
\text { Creek }\end{array}$ & 13,708 & 421 & 2 & 1 & $\begin{array}{c}\text { Observation in } \\
2006\end{array}$ & No & Yes \\
\hline Upper Tule & $\begin{array}{l}\text { Tule River and Lewis } \\
\text { Creek }\end{array}$ & 21,648 & 1,307 & 196 & 15 & $\begin{array}{c}\text { Observation in } \\
2010\end{array}$ & No & Yes \\
\hline Tulare County tot & & $\begin{array}{c}81,348 \\
(201,011)\end{array}$ & $\begin{array}{c}2,925 \\
(7,228)\end{array}$ & $\begin{array}{c}288 \\
(712)\end{array}$ & 10 & Detected & No & Yes \\
\hline \multicolumn{9}{|c|}{ Inyo County } \\
\hline Crowley Lake & Upper Owens River & 33,902 & 1,449 & 126 & 9 & Sparse & No & Yes \\
\hline $\begin{array}{l}\text { Death Valley- } \\
\text { Lower } \\
\text { Amargosa }\end{array}$ & Upper Amargosa River & 15,739 & 1,744 & 1,512 & 87 & Sparse & Yes & Yes \\
\hline $\begin{array}{l}\text { Eureka-Saline } \\
\text { Valleys }\end{array}$ & Eureka and Saline Valleys & 12,157 & 479 & 205 & 43 & $\begin{array}{c}\text { Observations } \\
\text { in } 1977, \\
2009 \text { and } \\
2019\end{array}$ & Yes & Yes \\
\hline Owens Lake & Lower Owens River & 42,423 & 1,681 & 1,656 & 99 & $\begin{array}{l}\text { Two } \\
\text { observations } \\
\text { in } 1891\end{array}$ & Yes & No \\
\hline Upper Amargosa & Lower Amargosa River & 3,391 & 801 & 572 & 71 & Common & Yes & Yes \\
\hline Inyo County total & & $\begin{array}{c}107,613 \\
(265,913)\end{array}$ & $\begin{array}{c}6,154 \\
(15,207)\end{array}$ & $\begin{array}{c}4,070 \\
(10,058)\end{array}$ & 66 & Detected & Yes & Yes \\
\hline
\end{tabular}


Table 3.1. Amount of suitable habitat predicted by model R30-P1 and conserved in the Least Bell's Vireo current and historic range in California.-Continued

[Hectares (acres) of suitable habitat and vireo detection history are listed by county, hydrological unit code (HUC) 8 watersheds, and associated major rivers and streams. Abbreviations: $<$, less than; $\geq$, greater than or equal to]

\begin{tabular}{|c|c|c|c|c|c|c|c|c|}
\hline $\begin{array}{c}\text { HUC8 } \\
\text { watersheds } 1\end{array}$ & Names of major rivers & $\begin{array}{l}\text { Hectares } \\
\text { (acres) } \\
\text { modeled }\end{array}$ & $\begin{array}{c}\text { Hectares } \\
\text { (acres) of } \\
\text { suitable } \\
\text { habitat }\end{array}$ & $\begin{array}{c}\text { Hectares } \\
\text { (acres) of } \\
\text { suitable } \\
\text { habitat } \\
\text { conserved }\end{array}$ & $\begin{array}{c}\text { Suitable } \\
\text { habitat } \\
\text { conserved } \\
\text { (percent) }\end{array}$ & $\begin{array}{c}\text { Least } \\
\text { Bell's Vireo } \\
\text { detection } \\
\text { history }^{2}\end{array}$ & $\begin{array}{l}\text { Historic } \\
\text { (<1990) } \\
\text { detection }\end{array}$ & $\begin{array}{c}\text { Recent } \\
(\geq 1990) \\
\text { detection }\end{array}$ \\
\hline \multicolumn{9}{|c|}{ Historic range - Continued } \\
\hline \multicolumn{9}{|c|}{ San Luis Obispo County } \\
\hline Central Coastal & $\begin{array}{l}\text { San Luis Obispo coastal } \\
\text { drainages }\end{array}$ & 65,203 & 2,511 & 812 & 32 & Sparse & No & Yes \\
\hline Cuyama & $\begin{array}{l}\text { Huasana and Cuyama } \\
\text { Rivers }\end{array}$ & 8,298 & 466 & 20 & 4 & $\begin{array}{c}\text { No } \\
\text { observations }\end{array}$ & No & No \\
\hline Estrella & Estrella River & 6,390 & 509 & 18 & 4 & $\begin{array}{c}\text { No } \\
\text { observations }\end{array}$ & No & No \\
\hline Salinas & Southern Salinas River & 33,518 & 938 & 124 & 13 & $\begin{array}{c}\text { Observation in } \\
1947\end{array}$ & Yes & No \\
\hline Santa Maria & Santa Maria River & 6,615 & 979 & 47 & 5 & $\begin{array}{c}\text { Observation in } \\
1993\end{array}$ & No & Yes \\
\hline San Luis Obispo & ounty totals & $\begin{array}{c}120,025 \\
(296,582) \\
\end{array}$ & $\begin{array}{c}5,402 \\
(13,350) \\
\end{array}$ & $\begin{array}{c}1,022 \\
(2,524)\end{array}$ & 19 & Detected & Yes & Yes \\
\hline \multicolumn{9}{|c|}{ Kern County } \\
\hline $\begin{array}{l}\text { Middle Kern- } \\
\text { Upper } \\
\text { Tehachapi- } \\
\text { Grapevine }\end{array}$ & Lower Kern River & 48,161 & 1,688 & 767 & 45 & Sparse & Yes & Yes \\
\hline South Fork Kern & South Fork of Kern River & 14,007 & 995 & 500 & 50 & Sparse & Yes & Yes \\
\hline Tulare Lake Bed & $\begin{array}{l}\text { Drainages in northwest } \\
\text { Kern County }\end{array}$ & 11,482 & 248 & 189 & 76 & $\begin{array}{c}\text { No } \\
\text { observations }\end{array}$ & No & No \\
\hline Upper Kern & North Fork Kern River & 2,637 & 160 & 59 & 37 & $\begin{array}{c}\text { No } \\
\text { observations }\end{array}$ & No & No \\
\hline Upper Poso & Los Posos Creek & 10,616 & 725 & 5 & 1 & $\begin{array}{c}\text { No } \\
\text { observations }\end{array}$ & No & No \\
\hline Kern County To & & $\begin{array}{c}86,903 \\
(214,738) \\
\end{array}$ & $\begin{array}{c}3,814 \\
(9,424) \\
\end{array}$ & $\begin{array}{c}1,519 \\
(3,753)\end{array}$ & 40 & Detected & Yes & Yes \\
\hline \multicolumn{9}{|c|}{ Santa Barbara County } \\
\hline $\begin{array}{l}\text { Santa Barbara } \\
\text { Coastal }\end{array}$ & $\begin{array}{l}\text { Point Conception and } \\
\text { Santa Barbara coastal } \\
\text { drainages }\end{array}$ & 38,657 & 423 & 115 & 27 & Sparse & No & Yes \\
\hline Santa Ynez & Santa Ynez River & 40,704 & 2,664 & 529 & 20 & Sparse & Yes & Yes \\
\hline San Antonio & San Antonio Creek & 12,047 & 707 & 5 & 1 & $\begin{array}{c}\text { No } \\
\text { observations }\end{array}$ & No & No \\
\hline Santa Maria & Santa Maria River & 15,193 & 1,510 & 234 & 15 & Sparse & Yes & Yes \\
\hline Cuyama & Cuyama River & 9,126 & 729 & 79 & 11 & $\begin{array}{c}\text { No } \\
\text { observations }\end{array}$ & No & No \\
\hline \multicolumn{2}{|c|}{ Santa Barbara County totals } & $\begin{array}{c}115,727 \\
(285,962)\end{array}$ & $\begin{array}{c}6,033 \\
(14,906)\end{array}$ & $961(2,374)$ & 16 & Detected & Yes & Yes \\
\hline \multicolumn{2}{|c|}{ Historic range totals } & $\begin{array}{c}2,468,491 \\
(6,099,642)\end{array}$ & $\begin{array}{c}145,146 \\
(358,656)\end{array}$ & $\begin{array}{c}30,300 \\
(74,872)\end{array}$ & 21 & & & \\
\hline
\end{tabular}


Table 3.1. Amount of suitable habitat predicted by model R30-P1 and conserved in the Least Bell's Vireo current and historic range in California.-Continued

[Hectares (acres) of suitable habitat and vireo detection history are listed by county, hydrological unit code (HUC) 8 watersheds, and associated major rivers and streams. Abbreviations: $<$, less than; $\geq$, greater than or equal to]

\begin{tabular}{|c|c|c|c|c|c|c|c|c|}
\hline $\begin{array}{c}\text { HUC8 } \\
\text { watersheds } 1\end{array}$ & Names of major rivers & $\begin{array}{l}\text { Hectares } \\
\text { (acres) } \\
\text { modeled }\end{array}$ & $\begin{array}{c}\text { Hectares } \\
\text { (acres) of } \\
\text { suitable } \\
\text { habitat }\end{array}$ & $\begin{array}{l}\text { Hectares } \\
\text { (acres) of } \\
\text { suitable } \\
\text { habitat } \\
\text { conserved }\end{array}$ & $\begin{array}{c}\text { Suitable } \\
\text { habitat } \\
\text { conserved } \\
\text { (percent) }\end{array}$ & $\begin{array}{c}\text { Least } \\
\text { Bell's Vireo } \\
\text { detection } \\
\text { history2 }\end{array}$ & $\begin{array}{c}\text { Historic } \\
(<1990) \\
\text { detection }\end{array}$ & $\begin{array}{c}\text { Recent } \\
(\geq 1990) \\
\text { detection }\end{array}$ \\
\hline \multicolumn{9}{|c|}{ Imperial County observations outside the Least Bell's Vireo historic and current range } \\
\hline \multicolumn{9}{|c|}{ Imperial County } \\
\hline Salton Sea & $\begin{array}{l}\text { Alamo and New Rivers } \\
\text { and Salton Sea }\end{array}$ & 99,416 & 7,691 & 1,456 & 19 & Sparse & No & Yes \\
\hline San Felipe Creek & San Felipe Creek & 1,827 & 126 & 115 & 91 & $\begin{array}{c}\text { No } \\
\text { observations }\end{array}$ & No & No \\
\hline \multicolumn{2}{|c|}{ Imperial County totals } & $\begin{array}{c}105,698 \\
(261,181)\end{array}$ & $\begin{array}{c}9,136 \\
(22,572)\end{array}$ & $\begin{array}{c}2,741 \\
(6,722)\end{array}$ & 30 & Detected & No & Yes \\
\hline
\end{tabular}

1We evaluated California HUC8 watersheds within the Least Bell's Vireo historic and current ranges. We did not include Arizona HUC watersheds falling within the range of the Arizona Bell's vireo (Vireo bellii arizonae). We included Imperial County HUC8 watersheds outside the current and historic range in California, but with multiple recent Bell's vireo observations.

${ }^{2}$ We included breeding season observations of presumed and confirmed Least Bell's Vireos in our detection histories. We excluded birds assigned to other subspecies or migratory and winter observations of birds that are not tied to suitable breeding habitat. 
For more information concerning the research in this report, contact the

Director, Western Ecological Research Center

U.S. Geological Survey

3020 State University Drive East

Sacramento, California 95819

https://www.usgs.gov/centers/werc

Publishing support provided by the U.S. Geological Survey

Science Publishing Network, Sacramento Publishing Service Center 


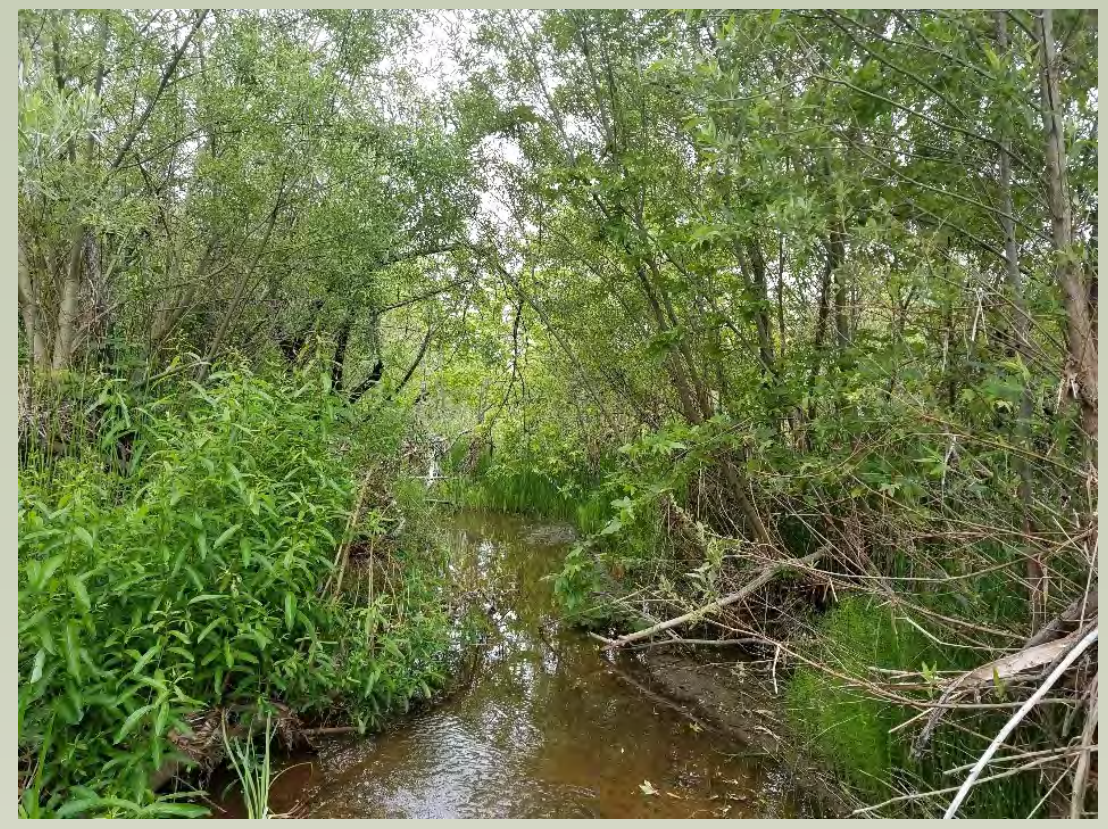

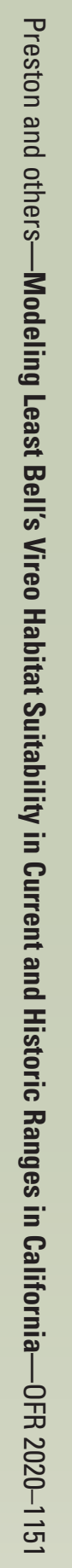

